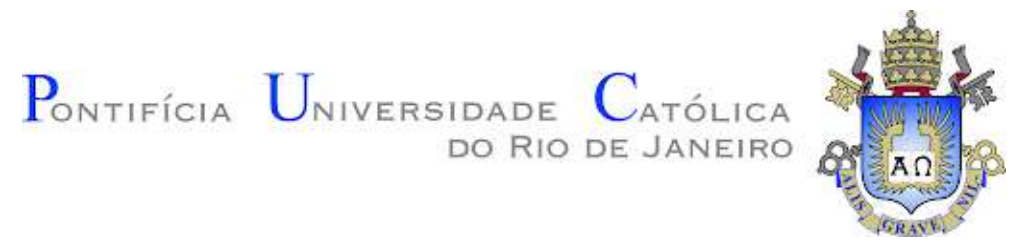

João Vitor Léste

The Informational Ergonomics of Tabletop

Games' Rulebooks

An analysis on informational hierarchy and

organization

\title{
Masters Dissertation
}

Dissertation presented as a partial requisite to obtain the degree of Master in Design by the Post-Graduate Program in Design, by the Department of Arts and Design at PUC-Rio

Advisor: Prof. Claudia Renata Mont'Alvão Bastos Rodrigues 


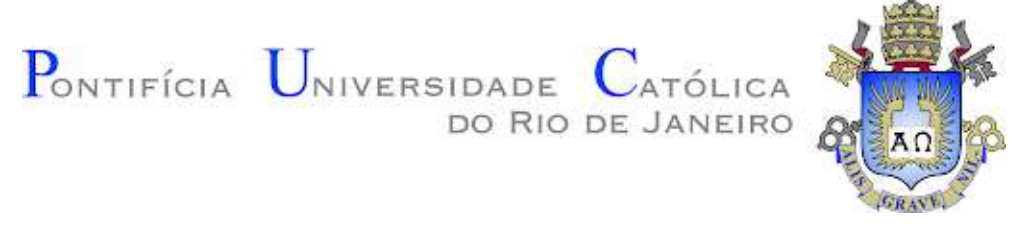

The Informational Ergonomics of Tabletop

Games' Rulebooks:

An analysis on informational hierarchy and

organization

Dissertação apresentada como requisito parcial para obtenção do grau de Mestre pelo Programa de Pós-Graduação em Design da PUC-Rio. Aprovada pela Comissão Examinadora abaixo.

Claudia Renata Mont'Alvão Bastos Rodrigues

Orientador

Departamento de Artes \& Design - PUC-Rio

Guilherme de Almeida Xavier

Departamento de Artes \& Design - PUC-Rio

Mikaël Le Bourhis

Asmodee Research

Rio de Janeiro, 18 de Fevereiro de 2021 
Todos os direitos reservados. A reprodução, total ou parcial, do trabalho é proibida sem autorização da universidade, da autora e do orientador

João Vitor Léste

Graduou-se em Design na PUC-Rio (Pontifícia Universidade Católica do Rio de Janeiro) em 2018. Foi professor de redação voluntário no Pré Vestibular Comunitário da Igreja Pastoral da PUC-Rio de 2018 a 2020. Participou de diversos congressos das áreas da Ergonomia e dos Estudos Lúdicos, além de ter participado da equipe de organização do $17^{\circ}$ Ergodesign \& USIHC. É voluntário na Associação Cidadão Pró Mundo, premiada a melhor ONG Brasileira do Setor de Educação no ano de 2020, desempenhando as funções de Professor de Inglês e de Coordenador de Comunicação e Eventos. Membro ativo do Colegiado de Representação Discente do PPGDesign (Programa de Pós Graduação em Design) da PUC-Rio.

Bibliographic Data

Léste, João Vitor

The informational ergonomics of tabletop games' rulebooks : an analysis on informational hierarchy and organization / João Vitor Léste ; advisor: Claudia Renata Mont'Alvão Bastos Rodrigues. 2021.

$165 \mathrm{f}$. : il. color, $; 30 \mathrm{~cm}$

Dissertação (mestrado)-Pontifícia Universidade Católica do Rio de Janeiro, Departamento de Artes e Design, 2021.

Inclui bibliografia

1. Artes e Design - Teses. 2. Jogos analógicos. 3. Manuais de jogos. 4. Hierarquia informacional. 5. Ergonomia. I. Rodrigues, Claudia Renata Mont'Alvão Bastos. II. Pontifícia Universidade Católica do Rio de Janeiro. Departamento de Artes e Design. III. Título. 
Para os meus pais, Marlene e Mário, que me proporcionaram tudo o que eu já precisei, e mais.

For my parents, Marlene and Mário, who provided me with everything I ever needed, and more. 


\section{Agradecimentos}

Aos meus pais, Mário Rogério Léste e Marlene Sessa Léste, que me sustentaram e apoiaram em meu sonho de ingresso na vida acadêmica, e à toda a minha família, em especial meu padrinho, Alexandre Zaluar, e minha madrinha Mônica Ribeiro.

À minha orientadora, Claudia Mont'Alvão, pela confiança, pelo apoio, e pelas inúmeras oportunidades que me ofereceu ao longo deste processo.

Ao LEUI, meu Laboratório de Pesquisa, e todos os seus participantes, pelas inúmeras discussões frutíferas e críticas construtivas.

Ao Colegiado de Representação Discente do PPGDesign PUC-Rio, membros passados, presentes e futuros, pela defesa aos interesses do alunato.

A todo o alunato do PPGDesign, em especial à turma de 2019, pela parceria, apoio, trocas e pelas discussões sobre o design de sobrancelhas.

À Direção do Departamento de Artes e Design da PUC-Rio e à Coordenação do PPGDesign, que tanto advogam pela permanência de todo o alunato no programa.

A Arnaldo V. Carvalho, que me incentivou durante todo o meu percurso desta dissertação, e a todas as pessoas que fazem parte do grupo Ludus Magisterium.

O presente trabalho foi realizado com apoio da Coordenação de Aperfeiçoamento de Pessoal de Nível Superior - Brasil (CAPES) - Código de Financiamento 001. Também contou com auxílio da Fundação de Amparo à Pesquisa do Estado do Rio de Janeiro - FAPERJ, com a Bolsa FAPERJ Nota 10 - Modalidade Mestrado 


\section{Acknowledgements}

To my parents, Mário Rogério Léste and Marlene Sessa Léste, who provided for me and supported me in my dream of starting my academic life, and to my family, especially my godfather, Alexandre Zaluar, and my godmother, Mônica Ribeiro.

To my advisor, Claudia Mont'Alvão, for her trust, support, and for the countless opportunities that she provided for me during this process.

To LEUI, my Research Lab, and all its participants, for the countless fruitful discussions and constructive criticism.

To the Collegiate of Student Representation from PPGDesign - PUC-rio, members past, present and future, for always defending the student's interests.

To all PPGDesign students, especially the ones from the 2019 class, for the partnership, support, exchanges and the many discussions about eyebrow design.

To the Directorate of the Department of Arts and Design - PUC-Rio, and to the Coordination of the PPGDesign, who advocate for the maintenance of all of the student body on the Post-graduate Program.

To Arnaldo V. Carvalho, who encouraged me during the course of my dissertation's development, and to all the people in the group Ludus Magisterium.

This study was financed in part by the Coordenação de Aperfeiçoamento de Pessoal de Nível Superior - Brasil (CAPES) - Finance Code 001. It was also supported by the Fundação de Amparo à Pesquisa do Estado do Rio de Janeiro FAPERJ, with the FAPERJ Nota 10 scholarship - Masters Modality. 


\section{Abstract}

Léste, João Vitor; Rodrigues, Claudia Renata Mont'Alvão Bastos. The Informational Ergonomics of Tabletop Games' Rulebooks: an analysis on informational hierarchy and organization. Rio de Janeiro, 2021. 160p. Dissertação de Mestrado - Departamento de Artes e Design, Pontifícia Universidade Católica do Rio de Janeiro.

By dwelling on the area of Playful Studies, it becomes hugely noticeable that games are often regarded as educational tools of socio-anthropological phenomena. So far, very little has been discussed about the board game learning process, and even less about their rulebooks, which tend to be sidelined even during the development and production of tabletop games. For this reason, this dissertation aims to start a conversation about tabletop games' rulebooks, culminating in a proposition of new criteria that can be used to better organize the information contained in rulebooks of tabletop games. Those criteria were determined from the standpoint of Informational Ergonomics and Human Factors. Considering the shortage of bibliography regarding this specific matter, the theoretical foundation has been built upon the literature review of works in the fields of Informational Ergonomics, Playful Studies, Cognitive Psychology, Linguistics and Education - presented in chapters 2 through 4 . The relevant concepts and ideas found on these works were then adapted to the context of the Informational Hierarchy of Tabletop Games' Rulebooks, specifically during the first time when players were interacting with the games and their rulebooks. In order to evaluate how useful those findings were in practice, a round of interviews was conducted with game designers who have previous experience with writing rulebooks - either for their games or as a consultant. Their answers, along with the theoretical foundation previously mentioned, served as the foundation to propose a list of guidelines, that aim to help organize the information contained in tabletop rulebooks and the usage of complementary images to better explain the 
game's rules. Those guidelines were then put to the test by means of an experiment, in which participants were invited to take part in a playtest of two well-known games: "No Thanks!" and "SET". Each group of players interacted with the two games: the first, containing its original rulebook; the second, containing a revised version, based on the previously mentioned criteria or organization. To evaluate the group's performance, five variables were analyzed: Time elapsed while reading the rulebook; time elapsed during the game; the quantity of mistakes made; the quantity of pauses in order to revise the game's rules; and time elapsed while revising the game's rules. On top of that, the participants' opinions and impressions were taken into consideration, in order to identify whether the points of concern previously mentioned became apparent to them as well, as a result of their interactions with the games and their rulebooks. Afterwards, the experiment results were analyzed, in order to identify the extent of the impact that the new criteria had on the player's performance. Due to the pandemic and quarantine - caused by Covid-19-, this dissertation's final result is a revised proposal for the experiment - to be applied whenever the conditions once again favour the development of experimental and in-person research.

\section{Keywords:}

Tabletop Games, Rulebooks, Informational Hierarchy, Human Factors/ Ergonomics 


\section{Resumo}

Léste, João Vitor; Rodrigues, Claudia Renata Mont'Alvão Bastos. A Ergonomia Informacional de Manuais e Regras de Jogos Analógicos: análise da hierarquia e ordenação das informações. Rio de Janeiro, 2021. 160p. Dissertação de Mestrado - Departamento de Artes e Design, Pontifícia Universidade Católica do Rio de Janeiro.

Ao mergulhar na área dos estudos lúdicos, é possível notar que os jogos muitas vezes são estudados como ferramentas educativas ou fenômenos sócio-antropológicos. Até o momento, pouco foi discutido sobre os processo de aprendizado de jogos - e muito menos sobre os manuais de regras de jogos, que são constantemente negligenciados inclusive nos projetos e produção de jogos. Por este motivo, a presente dissertação tem como objetivo iniciar um diálogo sobre manuais de jogos, culminando na proposta de critérios de ordenação para as informações contidas nestes documentos, tendo como referência o ponto de vista da Ergonomia Informacional. Considerando a escassez de produção de bibliografia específica sobre o assunto, a fundamentação teórica foi construída a partir da revisão bibliográfica de literatura referente às áreas de estudo da Ergonomia Informacional, Estudos Lúdicos, Psicologia Cognitiva, Linguística e Educação - apresentados nos capítulos 2 a 4. Esses conteúdos foram, então, organizados no contexto da Hierarquia Informacional de Manuais de Jogos Analógicos, tendo como o foco o processo de aprendizado de regras em situações de primeiro uso. A fim de avaliar a aplicabilidade prática dos levantamentos realizados, foi conduzida uma rodada de entrevistas com game designers que possuem experiência com a redação de manuais de jogos - seja para jogos de 
autoria própria ou de terceiros. A partir das respostas das entrevistas, aliadas ao referencial teórico, foi então definida uma lista de diretrizes de ordenação das regras de manuais de jogos analógicos, além de critérios de utilização de imagens complementares ao texto. Por fim, estas diretrizes foram postas à prova por meio de um experimento de playtest, no qual usuários foram convidados a jogar dois jogos: "No Thanks!" e "SET". Cada grupo de usuários - composto por grupos de 3 a 4 participantes - interagiu com um jogo com seu manual original e o outro com um manual revisado a partir das diretrizes definidas pela presente pesquisa. A fim de avaliar o desempenho de cada grupo, foram definidas as seguintes variáveis a serem analisadas: tempo de leitura do manual; tempo de jogo; quantidade de erros cometidos; quantidade de interrupções no jogo para revisar as regras; tempo total de interrupção do jogo para revisar as regras. Além disso, foi considerada a opinião de cada participante em relação à redação do texto, a fim de identificar se os pontos de atenção identificados em cada manual se tornaram aparentes durante a experiência de primeiro uso dos manuais e jogos em questão.

Foi feita uma análise da aplicação do experimento, identificando os impactos que as alterações do manual proporcionaram no desempenho dos participantes. Como resultado, e devido às limitações de contato físico e presencial decorrentes da situação de pandemia e quarentena, em função Covid-19, o resultado final desta dissertação é a proposta revisada do experimento, a ser aplicado em momento mais propício à pesquisas presenciais.

\section{Palavras-chave:}

Jogos Analógicos, Manuais de Jogos, Hierarquia Informacional, Ergonomia 


\section{Summary}

1. Introduction - Foreword 17

1.1. Introduction - Research Context 18

1.2. Research Subject $\quad 21$

1.3. Research Object 22

1.4. Research Problem 22

1.5. Main Objective 24

1.5.1. Specific and Operational Objectives 24

1.6. Research Hypotheses 25

1.7 Methodology and Techniques 26

$\begin{array}{ll}1.8 \text { Research's Relevance } & 27\end{array}$

2. Contexts and Elements of Playing: creator and creature of social structures $\quad 30$

2.1. Senet and the Social Context of Playing 31

2.2. The Objective of Playing 34

2.3. A counterpoint to viewing games as products 38

2.3.1. Tabletop Games as Tools for Social Inclusion 41

2.4. Conclusions and Takeaways 45

3. Cognitive Parameters Related to Learning Games' Rules 47

3.1 Rulebooks inside the scope of Educational Processes 51

3.2 Learning Curves in Tabletop Games 62

$\begin{array}{ll}\text { 3.3 Conclusions and Takeaways } & 65\end{array}$ 
4. Age Ratings for Tabletop Games 68

4.1. The Current Age Ratings for Tabletop Games 70

4.2. Children's Expected Skills at Different Ages 71

4.3. The BNCC and Game Requirements $\quad 74$

$\begin{array}{ll}\text { 4.3.1. Dr. Eureka } & 77\end{array}$

$\begin{array}{ll}\text { 4.3.2. No Thanks! } & 78\end{array}$

$\begin{array}{lr}\text { 4.3.3. Quartz } & 80\end{array}$

4.4. Conclusions and Takeaways 82

5. The Informational Hierarchy of Rulebooks 84

5.1. In Defense of Regulating Rulebooks 85

5.2. The Didactic and Human Factors/Ergonomics of Rulebooks 86

5.3. Interview with Rulebook Writers 94

5.3.1 Questions, Objectives and Analysis 95

5.3.2 Interview Debriefing 103

5.4. Ergonomic Criteria in Practice: an Analysis on Rulebooks and Video Tutorials

5.4.1. Coup - La Mame Games and Mandala Jogos 108

5.4.2. Nemesis - Rebel and Awakened Realms 111

5.4.3. Santorini - Spin Master, Roxley and Galápagos Jogos 115

$\begin{array}{ll}\text { 5.5. Conclusions and Takeaways } & 120\end{array}$

6. Experimental Research: Testing Rulebooks 122

6.1. Experiment's Description 122

6.1.1. The Revised Rulebooks - No Thanks! 125

6.1.2. The Revised Rulebooks - SET 126

$\begin{array}{ll}\text { 6.2. Conducting the Experiment (Pretest) } & 127\end{array}$ 
6.2.1. Conducting the Experiment (Pretest) - Group 1: No Thanks! 129

6.2.2. Conducting the Experiment (Pretest) - Group 1: SET 130

6.2.3. Conducting the Experiment (Pretest) - Group 2: No Thanks! 131

6.2.4. Conducting the Experiment (Pretest) - Group 2: SET 132

$\begin{array}{ll}\text { 6.3. Experiment's Analysis (Pretest) } & 134\end{array}$

$\begin{array}{ll}\text { 7. Conclusions and Results } & 138\end{array}$

$\begin{array}{ll}\text { 7.1. Caveats and Next Steps } & 144\end{array}$

$\begin{array}{ll}\text { 8. Bibliography } & 146\end{array}$

8.1 Complementary Bibliography 149

$\begin{array}{ll}8.2 \text { Ludography } & 150\end{array}$

$\begin{array}{ll}8.3 \text { Videos } & 152\end{array}$

$\begin{array}{ll}\text { Appendix I - Interview Script } & 154\end{array}$

Appendix II - Informed Consent Form (Interview) 157

Appendix III - Informed Consent Form (Experiment) 160

Appendix IV - Experiment's Datasheet 163 


\section{List of Figures}

Figure 1 - 2nd and 3rd pages of Combate's Rulebook. The original game was released in 1946 under the name of "Stratego".

Figure 2 - Painting depicting Queen Nefertari playing a match of Senet, found on her tomb

Figure 3 - Hnefatafl, Fox Games, Peg Solitaire and Frogriders, respectively.

Figure 4 - Interaction model between sensory memory, working memory, and long term memory in multimedia text processing, presented by Mayer (2014).

Figure 5 - Model of multimedia processing for rulebooks, proposed by this research based on Mayer's model (2014).

Figure 6 - Interaction model between sensory memory, working memory, and long term memory in multimedia text processing, presented by Mayer (2014).

Figure 7 - Model of multimedia processing for rulebooks, proposed by this research based on Mayer's model (2014).

Figure 8. Dr. Eureka simulated gameplay, found on Blue Orange's official website.

Figure 9. No Thanks product display, found on Papergames' official website)

Figure 10. Quartz Box and Components, took from author's copy of the game.

Figure 11 - Page from Duarte's Dissertation (2015), depicting his usage of images and footnotes.

Figure 12 - Top part of the first page from Frogriders' rulebook.

Figure 13 - Screenshot of an YouTube video page which depicts YouTube's tools of indexation.

Figure 14 - Brazillian Coup's components, following western patterns of reading: "The court" rulebook, Primary Rulebook, 
game box, Asylum card/rulebook, game chips, religion cards, character cards, and player aids.

Figure 15 - Excerpt from Brazilian Coup 's Rulebook, showing the only illustrations present in it. The image is available in the online repository "Ludopédia".

Figure 16 - Box contents from the prototype rulebook for Nemesis (Left); Game elements for the final rulebook for Nemesis (Right).

Figure 17 - Frame from the video tutorial for the game Nemesis, available on YouTube.

Figure 18 - Snapshot from the YouTube Page where the video tutorial for the game Nemesis is displayed, containing its index.

Figure 19 - Excerpt from Santorini's Rulebook, depicting God Cards and the contexts when they can be used.

Figure 20 - Page 1 of Santorini's rulebook.

Figure 21 - Page 2 from Santorini's Rulebook 118

Figure 22 - Frame from one of Santorini's Video Tutorials.

Figure 23 - On the left, the original version of No Thanks!'s rulebook; on the right, the revised version of No Thanks!'s rulebook, following this research's proposed criterion.

Figure 24 - Original version of SET's Rulebook.

Figure 25 - Revised version of SET;s Rulebook.

Figure 26 - Display of Group 1's and Group 2's interaction with the original and revised rulebooks.

Figure 27 - Comparison between how players arranged their cards in each group.

Figure 28 - Updated version of the proposed cognitive processing model of multimedia texts, in order to include video tutorials as well.

Figure 29 - Updated version No Thanks!'s revised rulebook.

Figure 30 - Updated version of SET's rulebook. 


\section{List of Tables}

Table 1 - Amount and percentage of respondents by self declared gender identity.

Table 2 - Amount and percentage of respondents by self declared sexuality.

Table 3 - Comparison Between Gagné's Model, Rowley's Model and this dissertation's Model.

Table 4. Comparison Between BNCC math skills, skills required to play a game, and types of games which require them. (Authors, 2019) 75

Table 5 - Comparison between Coup's Rulebooks and

Video Tutorials.

Table 6 - Comparison Between Video Tutorials and Rulebooks for Nemesis.

Table 7 - Comparison Between Gagné's Model, Rowley's Model and this dissertation's Model.

Table 8 - Data resulting from Group 2's performance while playing SET. Green cells highlight the best performance from each round, while red cells highlight the lowest, disconsidering ties.

Table 9 - Comparison between Group 1 and Group 2's performances. Green cells represent the better results, while red cells represent worse results.

Table 10 - Group 2's performance during their 4 rounds of SET. Red cells represent the worst performance in regards to that metric; dark green cells represent the best performance; and light green cells represent intermediate performances. 


\section{1}

\section{Introduction - Foreword}

This dissertation was initially planned and written in Portuguese, and the decision to translate it to english was only made two months prior to its defense, in order to better accommodate the members of the examination board. Thus, some arguments, terms and quotes were originally thought out in Portuguese, causing a natural dissonance when translated.

In order to remedy that, two strategies were put in place:

First, some words had to be kept in Portuguese, either because their etymology was relevant or because they do not have an adequate translation in English that would encompass their whole meaning. Whenever that happened, the word was presented in italic, and between "quotation marks" - with an adequate explanation of what it means, in English.

Secondly, quotes and citations that have been originally published in Portuguese, without available translations, were translated by the author. Whenever that happened, a footnote was added with the original text, as to not mislead readers into thinking that they have been published in english.

On the other hand, some attached documents, such as the Informed consent forms, were not translated, since the version that the participants signed was originally in Portuguese.

On top of that, following the APA guide of neutral language (2019), this dissertation will use the "singular they" pronoun whenever referring to a person whose gender is either unknown or irrelevant to the topic at hand. This choice was preferred over the "he or she" pronouns as it not only deflates the general male-oriented discourse present in older academic works, but also is inclusive of people of all genders. Any other formatting rule that does not have an exact correspondence between Portuguese and English was also changed to follow APA rules. Furthermore, whenever presenting lists, the use of the "oxford comma" was 
preferred; and in order to remedy situations that could incur ambiguity because of its usage, appositions were put between "-" symbols.

Besides, considering the current discussion about the User-Centered Design, Human-Centered Design, as well the coinage of the term "Patient-Centered Design" in the last decade, it becomes apparent that the context of use of any product or service is of utmost importance when analyzing it. For that reason, this dissertation advocates in favour of "player-centered design", using the term "player" as akin to the term "user", for all ergonomics-related purposes.

Moreover, due to the Covid-19 pandemic and the safety measures that were put in place in Brazil - starting in march, 2020 - it was not possible to follow through with part of the experimental research that was originally planned. Due to this fact, part of the methodology was revised, allowing for the dissertation to be completed in due time, while also not risking the lives and health of volunteers that would take part in the aforementioned activities.

\title{
1.1
}

\section{Introduction - Research Context}

The Portuguese language allows for a unique opportunity to evaluate the act of "playing". While it has a clear distinction between the verbs "jogar" and "brincar", other languages tend to bundle together the two: in English, there is the verb "to play"; in French, "jouer"; in Spanish, "jugar". On top of that, it is important to notice that, in many of those languages, those verbs also have abstract meanings that are not directly connected to the act of playing:

\begin{abstract}
Bomtempo (1997) points out that the designation used for "jogo" in English is "game", while for "brincar" the word "play" is used, but this term can also involve many other activities, like play [an instrument], painting, or taking part in a sports match. In french, we have something similar to the term "jeu" and "jouer" (game/match and play), which can be used in contexts that are not necessarily related with playful activities, like the stocks market, in political quarrels, etc. In the former Soviet Union, the word "Igrii", according to Elkonin (1998), was used as if it represented games of playing, that is, there also was not a clear cut etymological distinction of meanings. (PICCOLO, 2009, 927) ${ }^{1}$
\end{abstract}

\footnotetext{
${ }^{1}$ Free translation. Original text: "Bomtempo (1997) destaca que a categorização usada para jogo em inglês é game, já para brincar se utiliza o play, porém esse termo também pode envolver uma
} 
This is a phenomenon that can be observed in all 108 languages catalogued in Google's translation tools, the only exception being Portuguese. It is through this small linguistic peculiarity that a strong criticism can be made to some notions presented by Huizinga that playing precedes the civilizatory process that humanity went through. While the official English translation states that

\begin{abstract}
"PLAY is older than culture, for culture, however inadequately defined, always presupposes human society, and animals have not waited for man to teach them their playing. We can safely assert, even, that human civilization has added no essential feature to the general idea of play. Animals play just like men. We have only to watch young dogs to see that all the essentials of human play are present in their merry gambols. They invite one another to play by a certain ceremoniousness of attitude and gesture. They keep to the rule that you shall not bite, or not bite hard, your brother's ear. They pretend to get terribly angry. And what is most important - in all these doings they plainly experience tremendous fun and enjoyment. Such rompings of young dogs are only one of the simpler forms of animal play. There are other, much more highly developed forms: regular contests and beautiful performances before an admiring public." (HUIZINGA, 1949, 1)
\end{abstract}

it is important to notice that the kind of "playing" displayed by animals is much more akin to what is called "brincar", in Portuguese, but not "jogar".

On the other hand, this criticism must be accompanied by a healthy dose of self-awareness, as to not incur any kind of anachronism. By examining the different meanings behind the word "play" in different languages, it becomes clear that many definitions, similarities and differences are determined by social, cultural and even linguistic notions. In practice, this means that what could be considered "jogar" in some languages, places and times is not necessarily the same as in others; the same being true for "brincar":

\begin{abstract}
Brougère (1998), in his studies about the historical evolution of games in different cultures highlights that the act of playing [jogar] and the one of playing [brincar] take on diverse, and sometimes even conflicting, perspectives, due to the fact that its designations are strongly marked by social, political and ideological elements characteristic of specific historical contexts. Due to this fact, according to the author (op. cit.), the ideas people have about both variations of playing vary according to authors, periods of time and particular historical contexts. (PICCOLO, 2009, 927) ${ }^{2}$
\end{abstract}

gama de outras atividades, quais sejam tocar, pintar, participar de uma partida esportiva. Em
francês temos algo parecido com o termo jeu e jouer (jogo/brincadeira e jogar), os quais podem ser
utilizados em contextos não necessariamente relacionados com atividades lúdicas, tais como na
bolsa de aposta, no embate entre políticos, etc. Na antiga União Soviética, a palavra Igrii, de
acordo com Elkonin (1998), era utilizada como se representasse jogos ou brincadeiras, ou seja,
também não se notava uma distinção etimológica rígida de significados." (PICCOLO, 2009, 927)
${ }^{2}$ Free translation. Original text: "Brougère (1998), em seus estudos sobre a evolução histórica dos
jogos em diversas culturas, destaca que o jogar e o brincar assumem perspectivas diversas, algu- 
Therefore, considering the current state of academic development in the field, as well as considering that Huizinga's work, while still being extremely relevant, was among the first ones to discuss the subject, it becomes necessary to recontextualize and separate the two possible meanings for the verb "to play" and its derivatives.

By having the Portuguese language as a primary reference, there should be made a distinction between the part of playing that precedes human culture (brincar), displayed by animals in natura, and the post-cultural one (jogar). Despite their many intersections, in essence, the act of "jogar" is defined by the self-imposed rules that circumscribe it.

Those definitions, of course, do not mean that the act of "brincar" does not involve any rules, but they are much more intuitive, bendable, and rudimentary, much like Huizinga's description of how puppies play among themselves. This difference can be further demonstrated by the intuitive understanding of which activities would amount to a "brincadeira" ${ }^{3}$ and which ones could be considered "jogos"4: while someone might play (brincar de) tag, pretend, or skipping ropes, they would also play (jogar) chess, soccer, or poker. Moreover, the interfaces with which people interact can also be examined to help understanding both forms of playing: Toys (brinquedos - brincar) and Games (jogos - jogar).

Consequently, in this dissertation, whenever the verb "to play" - and its derivatives - is being used, it will be referring to the act of "jogar", most specifically games - unless specified otherwise. For this reason, whenever mentioned, the activity of playing shall be considered as follows: any activity, competitive or cooperative, which aims to entertain, which involves the participation of one or more parts, and which is bound by a clear set of rules that guide the participants to achieve any kind of goal, while also disqualifying anyone who breaks them.

\footnotetext{
mas vezes até conflitantes, devido ao fato de sua classificação ser fortemente marcada por elementos sociais, políticos e ideológicos característicos de um determinado contexto histórico. Devido a isto, de acordo com o referido autor (op. cit.), as idéias que se têm dos jogos e brincadeiras variam conforme autores, épocas e contextos históricos particulares." (PICCOLO, 2009, 927)

${ }^{3}$ Noun derived from the same radical as "brincar".

${ }^{4}$ Noun derived from the same radical as "jogar".
} 
In this regard, the comprehension of what any given games rules are, and which ones are in place while playing, is fundamental to allow games to be enjoyable, through the process of internal verisimilitude ${ }^{5}$ that the activity evoques. By taking part in a game, all present people firm a brief and informal social contract determining that their following interactions will be bound by what is allowed by the game's rules.

However, by perceiving the importance that the rules have in any given game, it is possible to realize that this specific notion of playful activities has not been adequately investigated by the scientific community: while a lot has been discussed about the importance of playing as a social activity, about gamification and the use of games in learning paradigms; very little has been said about the process of learning how to play these very games. On top of that, rulebooks which should be the main tool used to help people learn how to play - are particularly neglected as study subjects.

\section{2}

\section{Research Subject}

This research's subject is the apprehension, comprehension and application of games' rules by reading the games' rulebooks, considering that, usually, those processes take place in that specific order.

The term "apprehension" will be treated as "the process of interacting with new information in order to memorize it." The term "comprehension" will be treated as "the post-apprehension process that takes place after apprehending any information in order to assimilate its meaning to generate personal interpretations." Finally, the term "application" will be treated as "the process that takes place after comprehension, when personal interpretations are then applied to a practical context".

This subject will be evaluated and developed through the lens of Human Factors and Ergonomics, in order to evaluate the impact that the organization of

\footnotetext{
${ }^{5}$ The philosophical notion that something is more likely to happen or makes sense according to logical and theoretical frameworks that have been previously made clear.
} 
the information in rulebooks has in players' performances, especially during their first interactions with the games - when the learning processes are most relevant. However, in order to produce a relevant and thorough research, many other fields of study were also researched.

\section{3}

\section{Research Object}

This research's objects are tabletop games' rulebooks, focusing on their informational projects. Thus, it is essential to highlight that this is not a research about game design. Therefore any games that were selected to be evaluated were not judged by their features, playability or any quality: only how its rules are written and organized.

Consequently, this research is focused, specifically, on the informational ergonomics of the texts and images present in rulebooks and aims to analyze how efficient players are in retaining knowledge about games with which they interact for the first time.

\section{4}

\section{Research Problem}

Even after only a quick analysis, it becomes apparent that many rulebooks present in the tabletop market present a series of ergonomic inadequacies especially from older games, that were designed over 20 years ago ${ }^{6}$. They may vary from non-optimal fonts and font sizes, a lack of well established target audience, convoluted or complicated speech, and even to an apparent absence of clear guidelines on how to better organize the texts and images present in them. This phenomenon is especially true in Brazil, where many of the popular games

\footnotetext{
${ }^{6}$ The oldest rulebook ever found was the clay tablet that explains the Royal Game of Ur (2500 b.C.) in the cuneiform language, used in ancient Mesopotamia. However, the document has been deciphered rather than translated. For more information, see Finkel, 2007. For other classic games, such as Chess, not much information has been found about how its rules were taught and transmitted, so the research focuses on modern tabletop games from some decades ago.
} 
had rulebooks with only one color, convoluted texts, and inadequate images, as seen in Figure 1.

These inadequacies have the potential of directly and negatively impacting player's learning curves, which are going to be interpreted as "the data that can measure the capacity that someone has to apprehend, comprehend and apply the rules relevant to a given game." Because of the negative characteristics that many rulebooks seem to display, players are prone to misinterpreting rules while reading them, therefore sometimes feeling discouraged to interact and learn new games because the task of learning them might feel overwhelming and burdensome. Furthermore, when they effectively decide to do so, misunderstandings are not uncommon - compromising their experiences with the game.

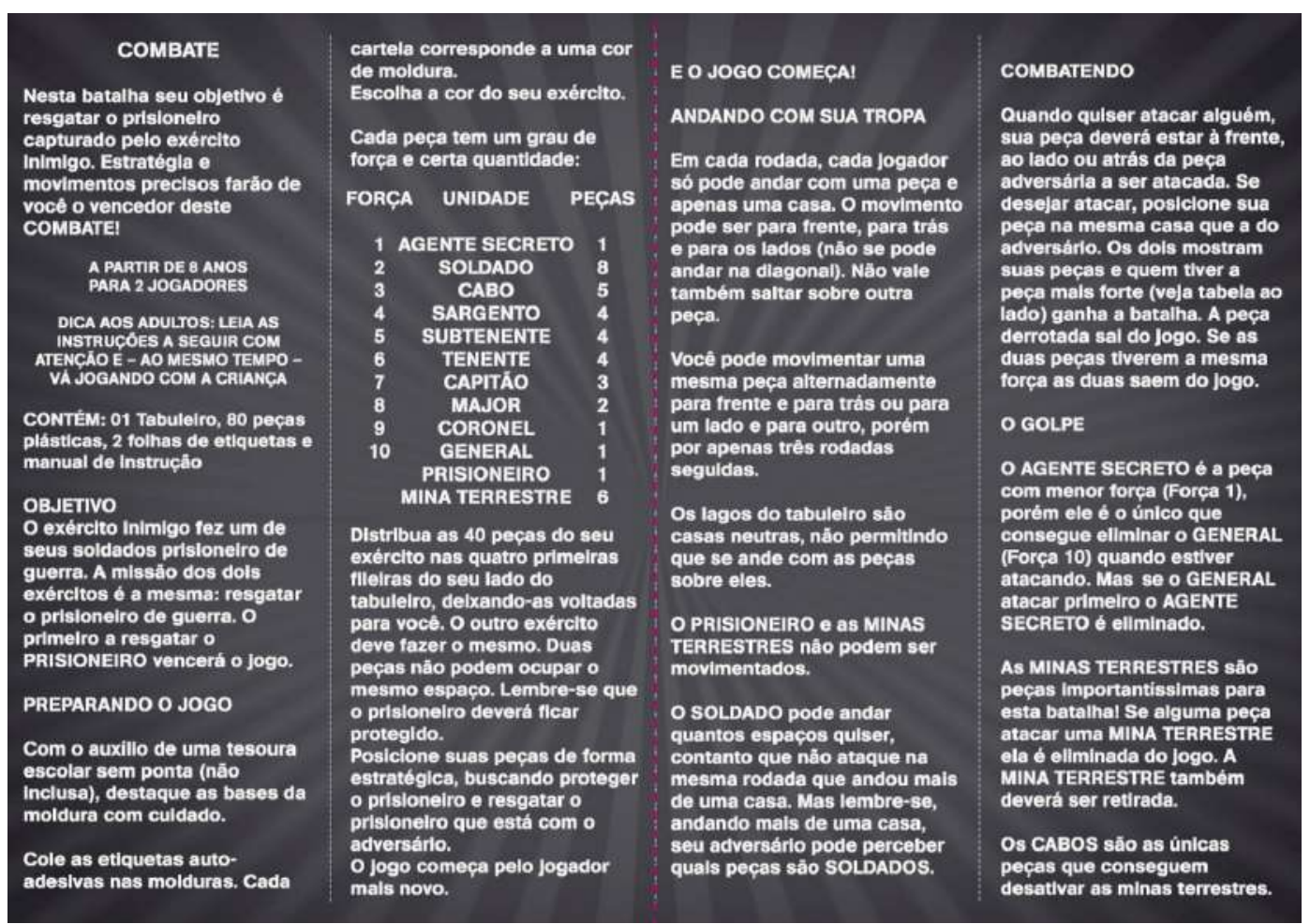

Figure $1-2$ nd and 3rd pages of Combate's Rulebook. The original game was released in 1946 under the name of "Stratego". 


\section{5}

\section{Main Objective}

This research's main objective is to investigate the relationship between the organization of rules in tabletop games' rulebooks with the performances displayed by players, the first time they interact with a game.

\subsection{1}

\section{Specific and Operational Objectives}

This research's specific objectives are the different aspects and steps that needed to be completed in order to achieve the main objective. Likewise, each operation objective amounts to a specific task or goal to fulfill its respective specific object. They are as follows:

I) Identify social, cultural, cognitive, psychological and linguistic aspects that can influence the process of learning tabletop games' rules:

- Review relevant bibliography of each of those areas of study.

- Propose a cognitive processing model to explain how tabletop game's rules are apprehended, comprehended, and applied.

II) Study the informational hierarchy of games' rules, identifying which are the essential information that should be in rulebooks, and the optimal criteria of organization for them:

- Review relevant bibliography composed of academic works and governmental documents that elucidate possible criteria for organizing rulebooks' contents.

- Interview game designers and rulebook writers in order to collect their input about how the rules should be organized in a rulebook. 
III) Evaluate games that are currently being produced, sold and played, in order to identify whether their rulebooks follow those criteria:

- Perform a documentary review of relevant games in the past five years, in order to select subjects to be scrutinized.

- Evaluate complementary documents (video tutorials) to identify whether the people who produce them are following the criteria mentioned above.

IV) Test the impact of the proposed criteria on players' learning curves;

- Select games whose rulebooks do not follow the proposed criteria, but that can be easily edited in order to be compliant with it.

- Perform an experiment in order to evaluate participants performance when exposed to games with adequate and inadequate rulebooks.

\section{6}

\section{Research Hypotheses}

In order to properly translate this research's predictions, the following hypotheses were considered:

I) Defining clear and replicable criteria of organization for tabletop games' rulebooks will help producing rulebooks that are easier to read and comprehend.

II) The first information in rulebooks ${ }^{7}$ should be the game objective, in order to help players contextualize the significance of what is being learned.

III) Rulebooks whose information are properly organized will have positive impacts on players' performances, especially during first uses, reducing time spent reading them as well as the numbers of misunderstandings.

\footnotetext{
${ }^{7}$ Referring to their texts, not considering pre-textual elements, such as covers, forewords, etc.
} 
IV) After reading rulebooks that conform to the criteria of organization, players will make fewer mistakes during game sessions. For this purpose, "mistakes" are going to be considered: actions that break the game's rules; actions that, while not breaking any rules, are not allowed to be made at that point; actions that are allowed, but do not deliver the results that the player who is making them expected.

At the end of the research, those hypotheses were then re-examined, so as to identify whether the initial assumptions were correct, incorrect, or incomplete.

\section{7}

\section{Methodology and Techniques}

This research aims to analyze the informational project of rulebooks, as well as its impact on players' experiences with games. Therefore, it mixes both inductive and deductive processes. The inductive processes are present through the literary review that allows for generalizations to be inferred. At the same time, the deductive stem from the analysis of already published rulebooks, in order to identify specific pros and cons to the techniques that have been put in place, resulting in inputs to conduct experiments that will put them to the test.

As for the methodological approach, this research was conducted as an Action Research, since it must be conducted together with professionals and specialists in the field. Design, after all, is a field that is born from praxis, being at its best whenever it contrasts both the theoretical and practical sides of the coin.

With that in mind, the choice of the following techniques was made in hopes to achieve a minimum level of practical contribution that can be directly applied by rulebook writers, especially the ones who still do not have their own backlog of experience to rely on:

I) Theoretical Framework: 
A) Literature Review: considering the close to non-existent bibliography about rulebooks, a literature review was conducted on the areas of Ergonomics, Human Factors, Cognitive Psychology, Linguistics and Education.

B) Documental Review: evaluation of different games and rulebooks, in order to select the exemplary cases - both for the good and the bad - to help translating the previously acquired knowledge into the context of tabletop games and rulebooks.

II) Inquiry:

Semi-structured interview with game designers and rulebook writers, in order to compare the previously established theoretical framework with their practical experience on the field - generating more meaningful criteria of organization for rulebooks.

III) Experimentation

Comparative experiment (game with original rulebook vs. game with revised rulebook) that aims to put to test the previously established criteria in order to evaluate their impact on players' performance.

\section{8}

\section{Research's Relevance}

Besides the importance of tabletop games as learning tools (both formal ${ }^{8}$ and informal ${ }^{9}$ ) and socialization tools, during people's whole lives, they are an insurmountable source of entertainment, especially by the abundance of different styles, themes, dynamics, game mechanics and complexity levels.

\footnotetext{
${ }^{8}$ Educational games, normally designed for children in the literacy step of their development.

${ }^{9}$ Skills such as "learning to lose" can be taught to children through games.
} 
However, the lack of cognitive accessibility in rulebooks seems to favour a more oral-oriented culture around teaching and learning games, establishing some of the participants as responsible for the initiation process of new players. This asymmetrical relationship between participants often generates a feeling of unbalance in matches, negatively impacting the players' experiences with the game - which should be ludic, light, and pleasant. On the contrary it is not uncommon for animosities to arise, especially if the more experienced players fail - by choice or not - to display the full explanation for the rules.

That being said, it is crucial to value the democratization of access to those rules, in hopes to even the playing field, allowing for more positive game experiences and aiming to eliminate - or, at least, diminish - the idea that any one of the players would be some kind of "rulekeeper" and preside over the game, much like the "owner of the ball" in a childrens' group.

Furthermore, the market for tabletop games is on the rise, having a growing social, economical and educational relevance in western society. In this regard, this research's relevance is tied to its groundbreaking academic perspective on tabletop games' rulebooks for both the field of Design and Human Factors and Ergonomics, by establishing a direct dialogue with the fields of Linguistics, Cognitive Psychology, and Education, among others areas of study.

Each chapter between 2 and 5 proposes a specific outlook in the context of learning how to play games. Chapter 2 conducts a bibliographical research in the fields of sociology and cultural studies, to examine why people play games, which is crucial information to understand their motivations and, therefore, determine the best approach to understanding this learning process. Chapter three further develops this research, shifting to cognitive psychology and linguistics, in order to propose a model of cognitive processing that explains how people learn to play games. Chapter four examines didactic directives and official regulatory documents about instructional documents, in order to investigate whether the current proposed age rating for games are in compliance with the adequate theoretical frameworks.

Chapter five, then, conducts a bibliographical research on the fields of linguistics and ergonomics, in order to propose a new set of criteria of 
organization to rulebook's contents. Then, it compares those criteria with the experiences and input from game designers and rulebook writers. The next step was to evaluate three top-rated boardgames and their rulebooks, in order to determine if those criteria are already being considered by other professionals.

Chapter 6 , then puts those criteria to test, describing the application of an experiment's pretest, in which participants were invited to play two different games: one with its original rulebook; the other, with a revised one. Their performances were then measured, in order to re-evaluate the experiment and propose a revised plan for its application. 


\title{
2 \\ Context and Elements of Playing: creator and creature of social structures. ${ }^{10}$
}

According to Huizinga (1949), games should be interpreted as essential cultural elements. Being intrinsic to any community, they make up a cycle of mutual influence with mores, values, and social structures. Games are fundamental tools for learning how to live in society - whichever society that may be - because they often simulate relevant activities to that place, culture and time. Therefore, they are to be considered active agents in shaping societies and the relationships between those who inhabit them:

\begin{abstract}
We can perceive the dimension of games['s impact] in the civilizatory process by the accounts of how they arose and participated in different epoques and human cultures. The boardgame Senet, for example, is considered one of the oldest games in humanity, whose pieces were found in Ancient Egypt, on the tombs of the First Dynasty, approximately 3 thousand years b.C. Created for two players, the game consists of moving the pieces throughout the board, facing or creating blockages and overtakings in order to achieve the final goal, using mathematical logic - ability so present in the construction of great structures, such as the Pharaoh's pyramids. (PIMENTEL, NICOLAU, 2018, 211) ${ }^{11}$

Ian Bogost's book shifted the focus away from the narrative dimension of games and concentrated on the representational potential that originates from the procedural nature of games instead, their nature of being rule-based systems. Such a system is not set up at random, it is constructed following various conscious or unconscious assumptions about whatever the game is about. Embedded in a stock market game, for example, is a notion of how stock markets work. A game is, in Bogost's words, a "way to make claims about how things work". (Bogost 2010, apud Quasdorf, 2020, 106)
\end{abstract}

\footnotetext{
${ }^{10}$ Parts of this chapter were originally written as papers with different academic purposes. The first one, titled "O Fenômeno Cultural dos Jogos: criador e criatura dos costumes e estruturas sociais", (Unpublished) was the final-term paper to a class lectured as part of the Post-graduate Program in Design at PUC-Rio: "Design Epistemology". The second, titled "Eventos de Jogos Analógicos Enquanto Ferramentas de Construção Identitária LGBTI+", was a short paper presented at the 2020 SBGames. They were translated, edited and new references were added as well.

${ }^{11}$ Free translation. Original text: "Podemos perceber a dimensão dos jogos no processo civilizatório, pelos relatos de como estes foram surgindo e participando das diferentes épocas e culturas humanas. $\mathrm{O}$ jogo de tabuleiro Senet, por exemplo é considerado um dos mais antigos da humanidade, cujas peças foram encontradas no antigo Egito, nas tumbas da I Dinastia há cerca de 3 mil anos antes de Cristo. Criado para dois jogadores, o jogo consiste em se mover as peças pelo tabuleiro, enfrentando ou criando bloqueios e ultrapassagens para se chegar a um objetivo final, usando-se a lógica matemática. Habilidade tão presente na construção de grandes estruturas, como as pirâmides dos Faraós." (PIMENTEL, NICOLAU, 2018, 211)
} 
In this regard, while it is necessary to learn the game's rules in order to grasp "what 'holds' in the temporary world circumscribed by play" (Huizinga, 1949), it also works as a means to learn and simulate what "holds" in a day-to-day basis, working as a simulacra of tensions and conflicts of real life, that can be tested in a controlled environment before being put to the test.

\section{1}

\section{Senet and the Social Context of Playing}

According to the historian Alice Mabel Prates (2019) ${ }^{12}$ : "Historical references to which modern historians have access, in this case mostly of archeological status, point to Egypt as being the place of creation of the first boardgames (Marques, 2012 apud Padró, 2004). Pieces of the game Senet have been found in Pharaohs' tombs from the First Dynasty, around 3000 b.C. Beyond that, boards and boxes of this game were part of "all the items that typically decorated the homes of high ranking staff members of the time" (Sales, 2015), in the period stemming from the New Period, starting with the ruling of Amenhotep III (1391 a.C. - 1353 a.C.). In the tomb of Nefertari (1290 a.C. - 1254 a.C.), located on the Valley of the Queens, an image of the queen herself playing Senet was found demonstrating the presence of the game among the Pharaonic elite (Figure 2). The historian Margaret M. Bakos, in her article "Hobbies from a mythical Epoque: the Ancient Egypt"13 (2014), indicates the game Senet as a means of entertainment accessible both to the Pharaohs and to commoners. According to her, the game composed their "daily enjoyments" and was connected to the Hator, deity of all pleasures. ${ }^{14}$

\footnotetext{
${ }^{12}$ Statement collected via digital text messages, during conversation about this research, specifically to be added in this chapter.

${ }^{13}$ Free translation. Original text: Passatempos de uma Época mítica: o Egito Antigo

${ }^{14}$ Free translation. Original text: "As fontes históricas às quais atualmente os historiadores têm acesso, nesse caso principalmente de cunho arqueológico, apontam para o Egito como sendo local de criação dos primeiros jogos de tabuleiro (Marques, 2012 apud Padró, 2004). Peças do jogo Senet foram encontradas nas tumbas de faraós da I Dinastia, em cerca de 3.000 a.C. Além disso, tabuleiros e caixas deste jogo faziam parte de "todos os itens que tipicamente decoravam a casa de
} 


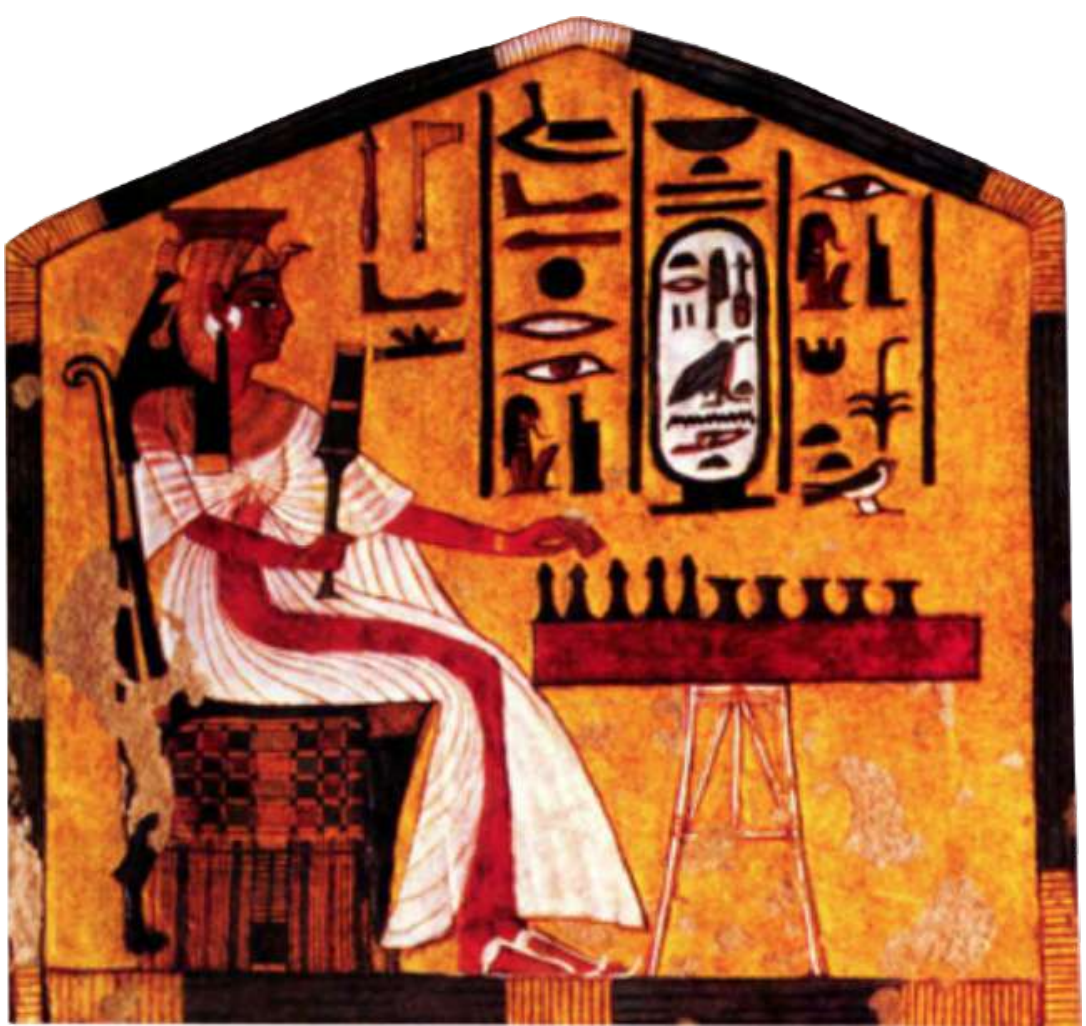

Figure 2 - Painting depicting Queen Nefertari playing a match of Senet, found on her tomb.

On the other hand, we verify that, in many ways, in quiet or agitated games, explicitly paying homage to a deity or in daily leisure activities, the ancient Egyptians demonstrated that it was necessary, in many moments, to set work aside and enjoy themselves.

Maybe it was impossible, at those times, to isolate the acts from the mythological explanations. Therefore we find a first relation between myths and Ancient Egypt's daily enjoyments: the reference to the goddess Hathor. (Bakos, 2014, p. 167) ${ }^{15}$

Still according to Prates, "we must remember, as the autor [Bakos] tries to demonstrate, that human life is not limited to the scope of work of the experience of slavery and, therefore, we must not underestimate the entertainment experiences of common Egyptians. Senet might be construed as a relevant part of

um alto funcionário da época" (Sales, 2015), no período do Império Novo a partir do reinado de Amenhotep III (1391 a.C. - 1353 a.C.). No túmulo de Nefertari (1290 a.C. - 1254 a.C.), localizado no Vale das Rainhas, também foi encontrada uma imagem que representa a rainha jogando o Senet mostrando a presença do jogo entre a elite faraônica. A historiadora Margaret M Bakos, em seu artigo "Passatempos de uma Época Mítica: o Egito Antigo", indica o jogo Senet como sendo um entretenimento acessível tanto à nobreza quanto a plebeus. Segundo ela, o jogo compunha os "divertimentos cotidianos" e estaria conectado à deusa Hathor, deidade de todos os prazeres."

${ }^{15}$ De outro lado, verificamos que, de diversas maneiras, em jogos quietos ou nos muito agitados, explicitamente homenageando um deus ou em atitudes descontraídas, os antigos egípcios demonstraram que era preciso, em certos momentos, deixar o trabalho de lado e divertir-se.

Talvez, fosse impossível, nessas horas, isolar das explicações mitológicas, os atos. Logo encontramos uma primeira relação entre a visão mitológica e os divertimentos cotidianos no Egito Antigo: a referência à deusa Hathor. (Bakos, 2014, p. 167) 
day-to-day life, which contributed to their individual and collective wellbeing, by being a game that involved knowledge and experiences shared by people. In this regard, it is possible to go beyond the author's [Bakos] hesitation in asserting that, in regards to Ancient Egypt, mythological explanations really shouldn't be separated from people's actions, since they confer meaning to them; beliefs are experienced through mores. Culture, of which both spirituality and leisure are part, is fluid and runs through social segments, even if it is not appropriated by every person in the same way ${ }^{16}$. So, it is most likely that the common Egyptian, who 'set their work aside' in order to play, had a different perspective about this activity than the one that Nefertari experienced, playing in her palace with finely decorated pieces." 17

Beyond that, it is also important to take into consideration that the choice of words "leisure time" and "set work aside" evokes a contemporary notion of entertainment, by insinuating the idea that all individuals were free to choose when they would work and when they would take part into other activities. Even though there were moments of leisure, it is essential to highlight that those moments were mostly determined by the Pharaohs, as said by Bakos herself in her book's introduction: "keeping in mind that, under the deified Pharaoh's mythical authority, besides work, subjects had moments of leisure"18. Furthermore, it is important to keep in mind the materiality of power dynamics in a highly hierarchical society such as Ancient Egypt was, in this case, limiting most

\footnotetext{
${ }^{16}$ To know more about differences in a given cultural setting, see BARTH, Fredrik. "O guru, o iniciador e outras variações antropológicas."

${ }^{17}$ devemos lembrar, como a autora tenta mostrar, que a vida humana não é limitada ao mundo do trabalho ou a experiência da escravidão e, portanto, não devemos subestimar as experiências de lazer dos egípcios comuns. O Senet pode ser lido como parte relevante do cotidiano, que contribuía para o bem-estar individual e coletivo, por ser um jogo que elencava conhecimentos e experiências comuns entre as pessoas. Nesse sentido, é possível ir além da hesitação da autora e afirmar que em se tratando do Egito antigo, as explicações mitológicas realmente não devem ser separadas dos atos das pessoas, visto que são conferidoras de significado; as crenças são vividas nos costumes. A cultura, da qual a espiritualidade e o lazer fazem parte, é fluida e perpassa os segmentos sociais, ainda que não seja apropriada por todas as pessoas da mesma forma. Assim, é provável que o egípcio comum, que deixava 'o trabalho de lado' e ia jogar, tivesse uma percepção deste momento de maneira bastante distinta que a rainha Nefertari, jogando em seu palácio com peças finamente decoradas.

${ }^{18}$ Free translation. Original text: "lembrando que, sob a autoridade mítica do faraó deificado, além do trabalho, os súditos tinham momentos de recreação".
} 
Egyptians' autonomy during their daily lives, since the context seems to be one of absolute pharaonic control over access to entertainment and games.

\title{
2.2
}

\section{The Objective of Playing}

Whenever a game is played, there is always a goal involved. According to the University College London (2002), using as a reference the 17th edition of their 1974's translation of the Book of the Dead ${ }^{19}$, playing senet was one of the activities intended as ritualistic in order to prepare oneself for the afterlife:

\begin{abstract}
Formulae for elevation and transfiguration, for going out from the necropolis, / for being in the following of Osiris [Egyptian deity that oversees the passage to the afterlife], and being content with the food of Wennefer [Osiris' High Priestess], / going out by day, taking any form desired to be taken, / playing the board-game senet, being in the pavilion, a living soul / the Osiris among the revered before the great Ennead [group of 9 High Deities from the Egyptian Pantheon] which is in the west, after he moors. / This is good for the one who does it on earth. / The words come to pass, in completion. (UCL, 2002)
\end{abstract}

In this regard, while Huizinga (1949) and Pimentel \& Nicolau (2018) affirm that ludic activities are birthing elements of social structures, the converse is also true, considering that social contexts also mold ludic manifestations in different communities. This phenomenon can be perceived in two different strands: the first, thematic, through which socio-cultural elements are incorporated in order to create and develop games; the second, goal-oriented, through which games are adapted in order to reflect and simulate relevant situations in that culture's context, seen as it is a tool used to achieve a goal.

To illustrate those adaptations, four games were selected, represented in fig. 2 , from different periods of time and also places in the world, that seem to be part of the same family of games. The game Hnefatafl is a Scandinavian game estimated to date as far back as 400 a.D. It is composed of a board, generally made of wood, and two asymmetric sets of pieces - which could only be moved to

\footnotetext{
${ }^{19}$ Sacred egyptian scriptures. This edition, by Allen, compiled papyruses that date from the New Reign (1570 b.C. - 1544 b.C.) and the Third Intermediate Period (1070 b.C - 664 b.C.)
} 

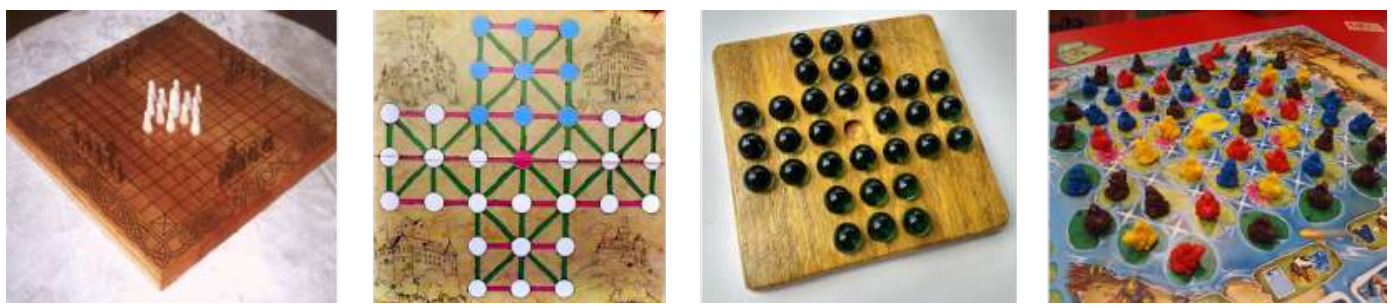

Figure 3 - Hnefatafl, Fox Games, Peg Solitaire and Frogriders, respectively.

adjacent squares in the board. The goal of the central army (white pieces) was to defend the king (the piece in the middle) while safely taking him to one of the edges of the board; as for the scattered army (brown), its objective was to capture the king, surrounding him with soldiers. There is an apparent thematic reference present in the form of Celtic runes drawn on the board, as well as the names of the pieces and actions that the player can take. At the same time, the goal-oriented influence comes from the fact that the logic and strategies developed by playing the game were akin to those put in practice during sieges, which were of utmost importance to Viking culture and economy, and also reflected the experiences of Viking folk during that period.

Its successor, "Fox Games" - also known as Halatafl - is a medieval game which also presents an asymmetric situation between players: while one manipulates the fox, whose objective is to eat all the geese, by hopping over them; the other controls all the geese, whose objective is to catch de fox, by surrounding it. This game had many regional variants, which represent it's thematic strand, with minimal differences: it's name, usually referring to native animals of the region, and the board's size.

There is an unmistakable resemblance to both of them, variants of the same genre of games, which use wooden boards flourished with cultural elements of the places where they were played, on top of the same game mechanics of capturing a piece of interest. Being a natural successor, Fox Games added a new possibility to that capture: the fox could hop over the geese. In Brazil, a local variation of the Fox Games was found, known as "Jogo da Onça"20, named after an animal that is

\footnotetext{
${ }^{20}$ There is no current official translation to the game's name, but it should be similar to "Jaguar Games" - although it is important to notice that while in Brazil "onça" is the name for jaguars, in Portugal it was used to refer to a group of lynx.
} 
very important to the region's indigenous culture, namely in Mato Grosso do Sul, São Paulo, and Acre ${ }^{21}$. It is alleged that the game originated from the Inca civilization (Ludopedia, s.d.). In this variation, the fox is substituted by a jaguar, and the geese by a pack of dogs, which were very relevant animals to the people who lived in those regions. The same is truth for "Bagh Chal", from Nepal, which depicts Tigers and Goats, and "Cows and Leopards", from Sri Lanka and India further indicating that the region in which a game is played influences which symbols are used in its design.

The third game, Peg Solitaire shrugs off many of the thematic aspects from its predecessors, normally using only a wooden board without any carvings. The game's paradigm also changed from a competitive two-player game to a single-player puzzle game, with the objective of having only one "solitary" piece left on the board.

While at first glance it seems to no longer represent a cultural paradigm, by not having any of the symbols that were present in both Tafl games, now Peg Solitaire takes on a different kind of cultural representation, that are directly tied to the materials and techniques used to make it, that were becoming increasingly popular, especially in Europe.

Moreover, on the goal-oriented front, there is evidence to support that its popularity was directly tied to the possibility of playing it alone. In the book "Knots and Borromean Rings, Rep-Tiles, and Eight Queens," Martin Gardner quotes a letter from Gottfried von Leibniz, written in 1716, about the game, describing his fascination with the game that "may provide a good half an hour of solitary entertainment". No wonder the game, which was popular both in England and France, was known as "Solitaire" - indicating that the mere ability to entertain oneself became a relevant goal for the game.

At last, the game Frogrides, released in 2017, appropriates many of the essential components and mechanics from Solitaire, but giving it a makeover more suited for modern tabletop games: the game is playable with $2-4$ players; the board is colorful and has drawings that are not only cosmetic, but are part of

21 "Esse jogo foi encontrado entre os Bororos, no Mato Grosso, onde é conhecido como Adugo, bem como entre os Manchineri, no Acre, e os Guaranis, em São Paulo." Text available in: https://www.ludopedia.com.br/ jogo/jogo-da-onca. Access on 02, dec. 2019. 
the game; there are cards with special powers that can turn the game on its head; as well as a scoring system to determine a winner - instead of encouraging players to achieve a specific game state in order to trigger the end-game scenario and be the winner. Aside from playability aspects it inherits from its predecessors, the game also incorporates elements that make up its new context, which depicts a "dispute between tribes of elves to determine which one has the best frogriders".

Despite the great popularization of the concept of "elves" after Tolkien's works $^{22}$, it is not hard to notice that Frogriders, a game about miniature elves that live in a society that stems from a frogriding-based culture, does not simulate any aspect of today's western society. In the previously mentioned games, especially the first two, the game itself paid homage to essential aspects in people's lives. On the other hand, Frogriders has a heavy cultural load associated with modern geek culture, relating to the interests of a huge target audience of people who are willing to spend money on geeky and nerdy memorabilia that reference fantastical or magical elements.

It is not uncommon for modern tabletop games to appropriate the game mechanics of classic games - oftentimes ones that are no longer relevant in the present consumer-based culture - and imbue them in fantastic elements to provide a new playing experience. This practice, widespread in the entertainment industry, with its numerous reboots of acclaimed classics and franchises, allows game designers to reinvent previously popular games, while making them palatable to newer generations that perhaps would have never taken any kind of interest in the previous installments.

This game design technique, much like any other phenomenon, must be evaluated through the socio-cultural lens of its time, in order to make sense of it. In this regard, according to Bonsiepe (2013), design must be understood through the lens of Late Capitalism, whose main objective is to maximize the market value of products, services and relations circumscribed by it.

While more subtle and elegant, the choice of using little elves and their froggy stallions as a marketing plus is somewhat akin to the hyper glamourization of the American Way of Life and the American Dream that some games - like

\footnotetext{
${ }^{22}$ Namely, the Silmarillion (1977), the Hobbit (1937) and the Lord of the Rings saga (1954-1955).
} 
Monopoly - evoque. Considering that there are upwards of 300 official versions of the game - many of them differing from other only by means of cosmetic variations - the experience of playing the game is no longer only tied to its entertainment value, but to their collectibility and to the cosmetic pleasure of having a version of Monopoly culture coated in someone's favorite TV show. This design process was heavily criticized by Forty in this chapter "Differentiation in Design" (1995), since it no longer ties the value of products to their functionalities and usabilities; instead, they take a back seat and the socio-esthetic reaffirmation that a given version of the product might generate will be the one taking the wheel.

Therefore, it becomes clear that, in the context of Late Capitalism, the production of games in large scale is mostly interested in their value as consumer goods, being motivated by the profit margins that they may provide. On the other hand, while appealing to a specific target audience, games like Frogriders seem to have a genuine intention of appealing to a niche of consumers that will truly enjoy the experience of playing a game about hopping frog knights, incorporating a new cultural element to the action of "hopping" game pieces, in order to make it more fun and entertaining.

In this sense, the game no longer simulates situations from real life, for which players must be prepared, now solely focusing on providing players with newfound experiences that they could not have in their daily lives. Hence, games are no longer mimetic tools to simulate a previously established culture, but the creators of their own context by providing people with exotic experiences.

\section{3}

\section{A counterpoint to viewing games as products}

In the last decade, there was a rise in game-related phenomena all around the world. The original game designers were artisans, encumbered of creating personalized game pieces for their customers. Nowadays, when thinking about game design, there are numerous niches of people taking on that mantle. One of particular interest are the Crowdfunding Campaigns, with astounding success 
rates, inviting people to make that game come true - either by contributing with ideas and inputs, or by investing in it in order to make the game's production process viable.

Similarly, the skyrocketing of game-themed bars, where customers pay a fee in order to gain access to the establishments' game library - suggests that subscription culture has also shaped the experience of enjoying games. Much like most people no longer own CDs and DVDs - instead paying to have access to their desired content Netflix, Hulu, Spotify, etc. - now customers no longer have to possess the games they enjoy, especially considering their high cost. In the introduction of his book "It's All a Game: The History of Board Games from Monopoly to Settlers of Catan," Tristan Donovan transcribes a report from the owner of a game-themed bar about the niche of more assiduous clients that they receive:

\footnotetext{
We're a big date spot. Weirdly, to me at least, we've become really popular in the Hasidic Jewish community. They see us as a fun, family-friendly, fairly safe place to take someone out on a very structured date, where it's public and not too dark. (Donovan, 2017, p. 4)
}

On the other hand, in the academic field, it is possible to see the insurgence of classes like Game Design ${ }^{23}$ (among others) in the curriculum of many Universities with different backgrounds; the rise in the usage of games as academic subjects of study, especially in the pedagogical field; the development of educational games, presenting a less artificial version of the ludification process of daily tasks and activities; and the usage of games as political tools - the latter being very evident in the projects of Fabio Lopez, a Brazillian Designer.

In his first project on the subject, called "War in Rio" (2007), show in figure 4, Lopez adapted the board from the popular game series War to depict the different favelas from Rio de Janeiro, in order to shed light on the constant war climate that many Cariocas ${ }^{24}$ have to face - which, oftentimes, are instigated by both criminal organizations and the police itself.

\footnotetext{
${ }^{23} \mathrm{https}$ ://www.puc-rio.br/ensinopesq/ccg/design midiadigital.html

${ }^{24}$ People who are born in Rio de Janeiro, Brazil.
} 

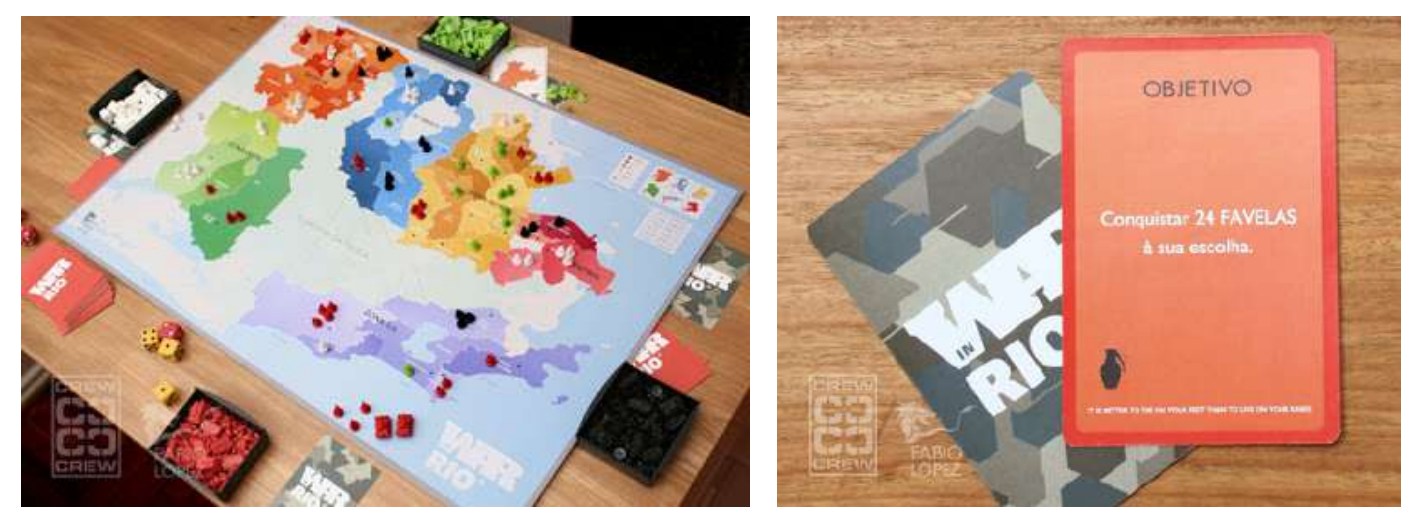

Figure 4 - War in Rio board, separated between Rio de Janeiro's communities (left) and objective cards (right).

The second one, called "Bando Imobiliário"25 (2010), shown in figure 5, builds a narrative similar to the previous one, denouncing the corruption and presence of parallel powers in Rio de Janeiro, by incorporating different elements of Carioca culture on the board. Beyond that, the game utilizes real headlines from newspapers depicting situations and events characteristic of Carioca suburbs into the "luck or reverse" cards - which are random events that will influence each players games separately - by utilizing specific language records of common usage by this part of the population.

At this moment, the game provides the language through which the designer can produce politically active content, imbued by criticism and commentary about the society and culture around them.
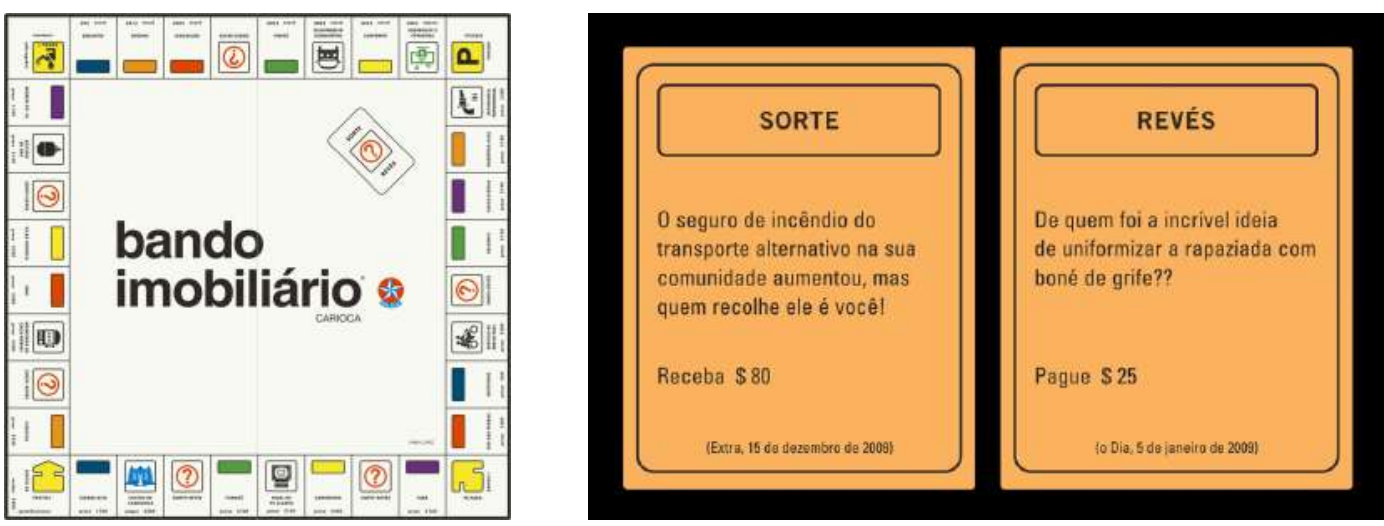

Figure 5 - Bando Imobiliário's Board next to cards of "Sorte" (Luck) e "Revés" (Setback)

\footnotetext{
${ }^{25}$ Wordplay around "Banco Imobiliário" (a translation of "Monopoly"). "Bando" is a way of referring to a group of people, oftentimes who engage in illegal or shady activities.
} 
Considering the game as a creator but also a creature of the social context in which it is inserted, being indissociable from the phenomena that surrounds it, it becomes apparent that, in the structure of Late Capitalism, design can also have a strong influence in how games can be idealized, even if not for monetary purposes. Furthermore, through design, this new wave of games can be composed of politically critical stances, becoming the designers' responsibility to provide an adequate scenario for those games to be thoroughly enjoyed by players.

\subsection{1}

\section{Tabletop Games as Tools for Social Inclusion}

For millennia, the LGBTI+ community has been under-represented, both in media (Bragança et al., 2016), politics (Reynolds, 2013), and history (Idier, 2018). By being the first sociologist and historian to compile a comprehensive archive of documents pertaining to this community, Antoine Idier points out that this lack of representation does not stem from an absence of LGBTI+ people in spaces, but instead for a lack on interest of hegemonic groups in documenting this group's history. Moreover, due to the stigma associated with queer people, their culture is often not only glossed over, but actively erased from mainstream culture.

This phenomena is especially negative for this community of people because their bonds as a population are not defined by hereditary, geographic, or ethnic characteristics, since there is no guarantee that there will be other LGBTI+ people in their families or social groups (Léste, 2020). Therefore, this lack of representation, allied with the absence of role LGBTI+ role models, often causes people from this community to build up their identities in solitary ways.

Their primary references about what it means to be a LGBTI+ person comes from the mainstream culture - that treats this group of people as second-class citizens. Furthermore, being an LGBTI+ person in Brazil, a country where they are systematically oppressed, repressed and murdered, influences the community to experience their identities through a lens of ostracism and negativity. 
For this reason, Idier proposes in his book "Archive des Mouvements LGBT+: Une Histoire de Lutte de 1890 à Nos Jours"26 (2018) that the LGBTI+ would benefit from a more hands-on approach to documenting their own history, "no longer relegating their representation to the hegemonic groups" (Léste, 2020).

In an attempt to achieve that, the monthly board game event "SeJogaBG" created a space of acceptance and inclusion for the LGBTI+ community, focusing on the inclusion and professionalization of queer people. The event welcomes people from all backgrounds, ethnicities, ages, gender identities, sexualities, and body types; and its main attraction is the monitoring team, which is composed of professionals that learn how to play games in order to teach them to the public. Monitors are also invited to familiarize themselves with politically correct speech, inclusive terms and practices, in order to treat the public in a polite and welcoming manner, no matter their personal characteristics. Also, other inclusive strategies are in place:

- The monitoring team is composed, in its majority, of LGBTI+ volunteers.

- Each event has a theme, which alternates between light hearted ones, such as Easter and Halloween, to political ones, such as Transgender Visibility in the LGBTI+ community.

- $\quad$ Participants may provide their personal details, such as self declared gender identity and sexituality, to help the event organizers measure the impact the event has on the LGBTI+ community.

- Free admission for transgender people, since they are a particularly vulnerable group, who is often marginalized from the workforce (Teixeira, 2019; Vasconcellos, 2014).

- Advertising the inclusive nature of the event through social media - namely Facebook and Instagram.

- Usage of the Pajubá dialect ${ }^{27}$ in social media posts.

- $\quad$ Posting content about boardgames and about LGBTI+ themes.

- Hosting a WhatsApp group open for event participants and sympathizers, which currently has a total of 132 participants.

\footnotetext{
${ }^{26}$ Free translation: "LGBT+ Movements Archive: a history of struggle from 1890 to our day."

${ }^{27}$ A unofficial dialect originated in Brazil which represents LGBTI+ terms and concepts.
} 
- Publishing photographs taken during the event by the photographic team in Facebook Albums, in order to document this LGBTI+ related event, creating a more decentralized representation of their own community.

In order to verify the impact that those practices had on the LGBTI+ community in Rio de Janeiro, an online survey was conducted in partnership with the Event's team. The survey was published on their social media and WhatsApp group, and had a total of 83 correspondents, which is half the average number of participants in each edition of the event. The respondent's self declared gender identity and sexuality were compared to the metrics of the past 12 editions of the event, in order to verify if they had a group diversity similar to the people who actually attended the event, as shown in tables 1 and 2 . The tables have a total of 3 columns of data: the first and the second, displaying respondents and their percentage of representation among the group, taking into account people who chose not to inform their gender identity or sexuality; the third, a corrected version of the event participant's percentage.

\begin{tabular}{|l|c|c|c|c|c|c|}
\hline \multirow{2}{*}{} & \multicolumn{2}{|c|}{ Survey } & \multicolumn{2}{|c|}{ Event } & \multicolumn{2}{c|}{ Event Corrected } \\
\cline { 2 - 7 } & $\#$ & $\%$ & $\#$ & $\%$ & $\#$ & $\%$ \\
\hline Total & 83 & $100 \%$ & 3876 & $100 \%$ & 3479 & $100 \%$ \\
\hline Cisgender Men & 50 & $60,24 \%$ & 1880 & $48,50 \%$ & 1880 & $54,04 \%$ \\
\hline Transgender Men & 1 & $1,20 \%$ & 5 & $0,13 \%$ & 5 & $0,14 \%$ \\
\hline Cisgender Women & 28 & $33,73 \%$ & 1027 & $26,50 \%$ & 1027 & $29,52 \%$ \\
\hline Transgender Women & 0 & $0,00 \%$ & 3 & $0,08 \%$ & 3 & $0,09 \%$ \\
\hline Non-Binary & 2 & $2,41 \%$ & 4 & $0,10 \%$ & 4 & $0,11 \%$ \\
\hline Gender Fluid & 1 & $1,20 \%$ & 0 & $0,00 \%$ & 0 & $0,00 \%$ \\
\hline Agender & 1 & $1,20 \%$ & 0 & $0,00 \%$ & 0 & $0,00 \%$ \\
\hline Other & 0 & $0,00 \%$ & 20 & $0,52 \%$ & 20 & $0,57 \%$ \\
\hline Not Informed & 0 & $0,00 \%$ & 397 & $10,24 \%$ & - & - \\
\hline
\end{tabular}

Table 1 - Amount and percentage of respondents by self declared gender identity. 


\begin{tabular}{|l|c|c|c|c|c|c|}
\hline \multicolumn{7}{|c|}{ Respondents by Sexuality } \\
\hline & \multicolumn{2}{|c|}{ Survey } & \multicolumn{2}{|c|}{ Event } & \multicolumn{2}{c|}{ Event corrected } \\
\cline { 2 - 7 } & $\#$ & $\%$ & $\#$ & $\%$ & $\#$ & $\%$ \\
\hline Total & 83 & $100 \%$ & 3876 & $100 \%$ & 3328 & $100 \%$ \\
\hline Heterosexual & 32 & $38,55 \%$ & 1431 & $36,92 \%$ & 1431 & $43,00 \%$ \\
\hline Homosexual & 30 & $36,14 \%$ & 858 & $22,14 \%$ & 858 & $25,78 \%$ \\
\hline Bisexual & 16 & $19,28 \%$ & 380 & $9,80 \%$ & 380 & $11,42 \%$ \\
\hline Pansexual & 5 & $6,02 \%$ & 20 & $0,52 \%$ & 20 & $0,60 \%$ \\
\hline Polisexual & 0 & $0,00 \%$ & 13 & $0,34 \%$ & 13 & $0,39 \%$ \\
\hline Asexual & 0 & $0,00 \%$ & 7 & $0,18 \%$ & 7 & $0,21 \%$ \\
\hline Other & 0 & $0,00 \%$ & 75 & $1,93 \%$ & 75 & $2,25 \%$ \\
\hline Not Informed & 0 & $0,00 \%$ & 548 & $14,14 \%$ & - & - \\
\hline
\end{tabular}

Table 2 - Amount and percentage of respondents by self declared sexuality.

The original online survey can be found on this link. Respondents were informed of their rights, and all of them had to declare that they were willing to participate. When asked about the impact that the LGBTI+ aspect of the event had on their perception of SeJoga $76 \%$ of the respondents declared that it motivated them to attend the event; $97,6 \%$ considered that it adequately welcomes diverse groups of people; $62,9 \%$ considered that it helps people learn about the LGBTI+ related topics; $95,7 \%$ considered that it results in meaningful representation of the community; and $68,9 \%$ considered that it documents day-to-day events of the LGBTI+ community in a meaningful way.

When asked to elaborate on their perceptions through essay answers, many respondents stated that they previously did not have adequate spaces to play boardgames, because most enthusiasts of the hobby are generally inserted in heteronormative, male-centered, and white spaces (Tocci, 2009; Jenkins, 2020).

Likewise, $40 \%$ of respondents stated that they had little-to-no previous knowledge about the LGBTI+ community before attending the event and reading their posts on social media, which demonstrates the social benefits of the event, which uses Tabletop Games as a tool for inclusion and education about marginalized groups. 


\section{4}

\section{Conclusions and Takeaways}

The first step to adequately propose new criteria of organization for tabletop games' rulebooks is to understand why people play games. Since games are an extremely relevant cultural aspect of humanity (Huizinga, 1949), this chapter presented a sociocultural analysis on the motivations behind playing games.

Like any other element of culture, games are influenced by the context in which they are played, but influence it as well. The Egyptians, a highly religious civilization, used Senet to worship their gods and prepare for rituals. The vikings, who were praised by their military accomplishments, trained logic and military strategies through Hnefatafl.

For this reason, it is not a surprise that games evolve hand-in-hand with social transformations and paradigm shifts in civilization. When vikings invaded, pillaged and settled in on European cities and villages, they most likely took Hnefatafl with them. Some centuries later, Fox Games - a game which incorporates many game mechanics from Hnefatafl - became widespread in Europe, depicting a common occurrence in that period of time: predators stealing farmers' animals. Moreover, the game was evidently culture coated to different regions of the continent, featuring animals that were native to each of them.

Eventually, in the Modern Age, the game Peg Solitaire took the place of Fox Games, presenting itself as a single-player game, without much variation aside from the materials used to make it. The game was seen as revolutionary, by providing people with the opportunity to entertain themselves.

In the 21 st century, Peg Solitaire was revolutionized by the new paradigm of modern game design, no longer portraying itself as a simulation of a social situation. Instead, Frogriders offers players a fantastical refuge from real life, incorporating elements of fantasy such as elves, to create a narrative about a frog-riding chivalry that must compete to prove themselves the best in the region.

Nowadays, games are generally produced in large-scale, being part of the Late Capitalism system, which favours the experience that users will have by 
consuming the game and interacting with it. However, much like any other cultural phenomena, it can be appropriated by any social groups or individuals to produce cultural meanings that are relevant to them: Fábio Lopez, a Brazillian Designer released parodies of famous games to create a political discourse about the violence that poor communities in Rio de Janeiro are subjected to. SeJogaBG, a monthly boardgame event from Rio de Janeiro uses games as tools for social inclusion of LGBTI+ groups.

However, no matter the objective behind producing or playing a game, one thing is certain: the game will only produce relevant experiences for the players if they can properly learn how to play them. 


\section{3 \\ Cognitive Parameters Related to Learning Games' Rules ${ }^{28}$}

According to an initial documentary research - which consisted on examining over one hundred rulebooks from popular games currently on Brazil's market of tabletop games ${ }^{29}$ - there does not seem to be a general consensus about how Tabletop Game's rulebooks should be designed or written. Because of that, there's an apparent dissonance between the organization of rulebooks from different games. This examination was also done to check if the information contained in rulebooks in the market have a deliberate organization to them, which is fundamental in determining which kind of learning situation they represent: formal ${ }^{30}$, non-formal ${ }^{31}$, or informal ${ }^{32}$.

It is also important to investigate other kinds of manuals, in order to determine which of their characteristics could be incorporated in Tabletop Games' Rulebooks. Furthermore, whenever dealing with tabletop games and their rules, there is a fundamental difference between them and their digital counterparts: while videogames have a machine or computer mediating the interactions between players and the game itself - allowing for the game to be learned while playing it; tabletop games rely on the cooperation between players, since the game itself only happens through their interactions with game components: the pieces only move

\footnotetext{
${ }^{28}$ Parts of this chapter were originally written as papers for different academic purposes. They were then revised and updated, in order to become more in tune with each other. New information and references were also added. Those papers are: "Tabletop Games' Rulebooks as Educational Tools: the development of strategies in tabletop games as learning situations" (Léste et al, 2019); and "Multimedia Comprehension in Practice: an analysis about tabletop games' rulebooks" (Léste, Unpublished).

${ }^{29}$ All those games are part of SeJogaBG's repository of games, which amounts to 311 games that have been donated by Brazillian game companies. Se Joga is a monthly board game event that happens in Rio de Janeiro, and focuses on the inclusion and professionalization of LGBTI+ people. The criteria of selection was based on the companies' demands and the necessity that at least 4 monitors should know a given game in order for it to be displayed at the event.

${ }^{30}$ Planned learning situations that are part of a curriculum, normally of a schooling system.

${ }^{31}$ Planned learning situations that tend to happen outside the schooling system.

${ }^{32}$ Spontaneous learning situations that happen in daily life.
} 
when they are moved, cards are only drawn if someone draws them; the board is only set if someone sets it.

This phenomenon of cooperation between players in order to make the game work is going to be addressed as the "Collective Intelligence" of the game. It is equivalent to a videogame's software that works through a logic of "If this action takes place, then this result should happen" and depends, primarily, on the players' ability to be in accord with what holds, according to the game's rules.

\begin{abstract}
The mechanics of Pandemic on Android are identical to those of the physical version. The challenges posed by the game's rules and the ways in which players can respond are indistinguishable between versions. In Pandemic, players can select up to four actions per turn from a list. The Android version presents these available actions at the bottom of the screen as buttons that perform the action when they are tapped. When codified, these rules are no longer optional. Players cannot make their own house rules in Pandemic's Android version nor accidentally cheat the game's systems. One potential benefit is that players do not need to understand the rules comprehensively to play. Physical Pandemic is simply a box of assorted objects until a player decides to read the rulebook. As the digital version reacts to their actions automatically, players can explore the game's mechanics and learn how they operate over time. (Stolee, 2020, p.15)
\end{abstract}

In order to achieve this level of accordance in tabletop games, players generally go through what is called "Suspension of Disbelief" - described by poet Samuel Taylor Coleridge, in 1817. According to him, it is a process of accepting that a hypothetical or fantastical situation "holds true", for the sake of entertainment. This is the process behind people's connection with fictional stories, since it allows the interlocutor to momentarily forget about their real lives and care about characters and situations that have no actual connections to them.

When applied to games, especially tabletop ones, the suspension of disbelief is what allows players to, for instance, not think about their actions in the game as the real actions being taken by them, but as the actions that they represent in-game: when someone is playing poker, they do not exclaim "I collected an Ace, King, Queen, Jack and 10 of the same suit, the strongest combination of cards in the game, and now am revealing them, which most likely means that I just won this round"; instead, they say "Read it and weep" while showing the other players the cards, and expect them to understand what it means.

This manner of communication, again, is only possible when all present players are aware of the rules, allowing for them to be in tune with the meanings 
and values of things that only make sense in the context of the game. Moreover, players must be willing to voluntarily limit themselves to the game, since they are the ones who must enforce the rules, while also abiding by them.

In order to maintain the necessary level of in-group accordance in regards to the rules that are in play, it is often advised for every player to be aware of all rules about the game in session. Otherwise, especially when someone is introduced to a new game, the burden or rulekeeper may fall on a more experienced player, favoring some players over others. One such situations was actually depicted on S06E06 $6^{33}$ of Friends (1994 - 2004), when Chandler makes up a new game called "Cups" in order to trick Joey into getting some money from him, since he was too prideful to accept help. By the end of the episode, Joey played "cups" with Ross, their other friend, and lost all the money he had previously won. Then, Chandler intervened and made up some new rules on the spot that he knew would favor Joey.

Although this is an exaggerated version of events, and Chandler did it intentionally, it highlights the amount of control he had over the other two, by being appointed as some sort of "ambassador" of the game's rules. However, in reality, other situations generally happen and end up negatively impacting players' experiences with games: picture three friends playing a game; Friend \#1, who is the only one who already knows the game and is teaching the other two how to play it; Friend \#2 and Friend \#3, who are both unfamiliar with the game. When \#1 finishes explaining how the game works, he forgot to explain a key rule. They then start playing and \#2 takes an action that is not allowed by the rule that has been forgotten, which will create a disadvantage to \#3. Now, \#1, who is the rulekeeper, must act as a regulator and decide whether to inform them of the mistake he made (favouring \#3 over \#2), or let the game play out (favouring \#2 over \#3).

If he chooses not to mention anything, the game will continue "normally", but they might encounter other problems later on, mostly if one of them plays with another group of people. Nevertheless, if he chooses to come forward, he

${ }^{33}$ S06 stands for "Season Six", while E06 stands for "Episode Six". S6E6 would also be acceptable, but whenever a show has 10 or more season, and each season has 10 or more episodes, the form with " 0 " is preferred. 
will undoubtedly upset $\# 2$, who made their game plan based on the information that had been communicated to them. In this situation, even the semblance of bias may damage their experience with the game, since the more inexperienced players might feel they have been robbed of their chance of winning.

The matter of semblance of bias is more commonly discussed in much more dire situations, such as the one posed by the paper "Do Appearances Matter?: Judicial Impartiality and the Supreme Court in Bush v. Gore Sherrilyn" (Ifill, 2002), discussing the impact that the appearance of partiality may pose to rulings in court. Another paper, "Regulating animals with gene drive systems: lessons from the regulatory assessment of a genetically engineered mosquito" (Meghani \& Kuzma, 2017), concludes that FDA's regulations should avoid even the appearance of possible bias in order to maintain the credibility and reliability that the institution currently has.

Similarly - given the due proportions - whenever a group of people play a game, the semblance of bias should also be avoided, as to nor disturb players neither hinder their enjoyment of the game. The ideal scenario would be for all involved players to read the rulebook and, afterwards, to go through a disambiguation round, when all players could ask questions and clear their doubts about the game while playing. By doing so, mistakes, pauses and misunderstandings could be much more efficiently avoided - situations that are damaging to the game's internal verisimilitude:

\footnotetext{
The rules of a game are absolutely binding and allow no doubt. Paul Valery once in passing gave expression to a very cogent thought when he said: " No scepticism is possible where the rules of a game are concerned, for the principle underlying them is an unshakable truth.". . ." Indeed, as soon as the rules are transgressed the whole play-world collapses. The game is over. The umpire's [referre's] whistle breaks the spell and sets "real" life going again. (Huizinga, 1949, p.11)
}

In reality, though, very few players have the patience to read rulebooks, instead relying on video-tutorials of more experienced players to teach them how to play. This situation may happen due to a natural dislike for long, complicated texts, but this dissertation hypothesizes that the lack of coherent criteria of organization may be a contributing factor since people who read a poorly 
designed manual - especially light users - will most likely refrain from this activity in the future.

\title{
3.1
}

\section{Rulebooks inside the scope of Educational Processes}

Whenever considering rulebooks, it is crucial to bear in mind their roles as educational materials, since they transmit new information to people who interact with them, which in turn is transformed into knowledge. Therefore, it is important to define in which category of learning they fit: formal, non-formal or informal.

In first analysis, the process of learning rules through rulebooks seems to fit the formal educational model - since it is used in many lessons, as part of the curriculum, during pre-school. However, starting in elementary schools, games are reserved for after-school or recess activities.

\begin{abstract}
Said research elected as a main problem source the dichotomization between playing and learning, installed in the educational context and which, as a consequence, sidelines games as pedagogical resources. This type of activity is treated, in educational institutions, as unnecessary or, then, is characterized, simply, as relaxation moments, resting and wearing out children's excedent energy. (Lima, 2008, 11) 34 $^{34}$
\end{abstract}

This paradigm shift coincides with the moment children start to have lessons about scientific subjects, indicating that games are not considered as valuable teaching tools - at least not currently, even though Trilla (2008) considers playing games as an educational activity in itself:

There is education, of course, in school and in the family, but it is also present in libraries, in museums, in long-distance educational processes, and playrooms. In the streets, in the movies, watching television and browsing the internet, in meetings, in games and toys (even if they are not the ones considered educational or didactic) etc. educational processes, equally, occur. (Trilla, 2008, 29) ) $^{35}$

${ }^{34}$ Free translation. Original text: "A referida pesquisa elegeu como principal problema a dicotomização entre o jogar e o aprender, instalada no contexto educacional e que promove, como conseqüência [sic], a secundarização do jogo como recurso pedagógico. Esse tipo de atividade é tratado, nas instituições educacionais, como prescindível ou, então, caracteriza-se, simplesmente, como momentos de relaxamento, descanso e desgaste de energia excedente das crianças." (Lima, 2008, p.11)

${ }^{35}$ Free translation. Original text: "Há educação, é claro, na escola e na família, mas ela também se verifica nas bibliotecas e nos museus, num processo de educação a distância e numa brinquedoteca. Na rua, no cinema, vendo televisão e navegando na internet, nas reuniões, nos jogos e brinque- 
Moreover, it is important to highlight that, even when present in the in-class environment of schools, games are more or less presented as a methodological tool in order to achieve other kinds of learning: a game may be used to teach children about losing, sharing, working together, or used to teach math, how to spell, etc. In this regard, the educational process being discussed is outside the game's scope, differently from what is being analyzed in this research: the process of learning how to play the game itself.

Still according to the Trilla's definitions, the process of learning a given game's rules does not seem to be characterized by informality, since there is a clear intent behind what is being learned - which happens systematically for each game, using the rulebooks as a primary source. Even if those instructions can be passed on via non-systematic and oral ways - when people teach each other how to play the games - it is always necessary for someone to have had an initial direct contact with the rulebook, going through the process defined by whoever wrote and designed it, with a specific beginning and a specific ending. Moreover, it has become increasingly common for people to learn games from professional explainers often present in thematic bars and events - who go through a training processes to become more apt to teach the game to customers.

Concerning the reason why someone might learn a game, it often is, primarily for entertainment. Even educational ones, which tend to favor learning about a specific subject, should be fun - or else people would just continue to read books about the subject. On second analysis, though, it needs to be remarked that any process of learning a game is, in its own regard, deliberate and must follow a coherent order, especially when reading the rulebook. In this regard, a rulebook might be construed as, for instance, a didactic textbook for a class: information is written in a specific order, thought to be the best order to attain the knowledge contained in it. After reading it, the reader becomes, in theory, capable of solving problems that are tied explicitly to the content at hand: for the textbook, they

dos (mesmo que eles não sejam dos chamados educativos ou didáticos) etc. ocorrem, igualmente, processos de educação." (Trilla, 2008, 29) 
might be able to solve math problems; for the rulebook, they might be able to play the game and win.

Consequently, the process of learning the rulebook must be understood as an in-between of formal and informal. It has a much too carefree objective of learning, more characteristic of the informal category: enjoyment. The rewards reaped by playing are often social or psychological ones, and even when learning how to play educational ones, the process of learning the game itself is still not a systematic part of the curriculum and, therefore, is not recognized by any type of official institution, degree, or certificate. On the other hand, it bears some characteristics of the formal category, such as having a deliberate order in which information must be apprehended and teaching readers how to solve problems on their own, resulting in its categorization as a non-formal process of learning.

With that in mind, it must be remarked that teaching people to solve problems independently is an uncommon goal for manuals in general - a group of which the rulebooks are part ${ }^{36}$. For the most part, manuals tend to have precise instructions for those who are reading them, not requiring many complex decision-making processes from readers: an applicant/candidate handbook will explain the exact steps that people need to take in order to apply for a spot; an assembly manual will detail each step of the assembly process, and must be followed to a tee; an user handbook will explain how to use a product. On the other hand, rulebooks, especially for tabletop games, must teach players how to decide what they want to do, by making them aware of a specific goal they should reach, explaining all the complexities that they must be overcome in order to do so, and explaining the options from which they must choose.

This ability to comprehend all those complexities in order to choose a course of action in order to achieve a specific goal, is what can be called "strategy", and can be described by two cognitive models of learning: Gagné's (1973) and Rowley's (2007).

According to Gagné, the ability to achieve this level of cognitive development is what is called "Problem-solving abilities," which is the highest

\footnotetext{
${ }^{36}$ Most of the documents presented in this chapter as manuals are called "manuals" in portuguese. Rulebooks: "Manuais de Regras"; Applicant/Candidate Handbook: "Manual de Candidato"; Assembly manual: "Manual de Montagem"; User's Handbook: "Manual de Uso".
} 
level of learning described by him in his book "The Conditions of Learning" (1973). According to him, there is a clear cognitive path that must be followed in order to achieve treal learning - which was adapted into a 6-step model, for the sake of simplicity ${ }^{37}$ :

1. Stimuli-response learning: the most basic level of learning, through which people can assimilate stimuli (visual, audible, tactile etc) with specific meanings and expected responses. e.g., "this shape is called a 'triangle'!"

2. Chains: establishing connections between different stimuli-response pairs as coherent and convenient orders, oftentimes through means of continuous repetitions. e.g., "all those shapes are triangles, but those others are not!"

3. Discrimination: understanding the differences between specific stimuli to generalize types of stimuli while being able to discriminate one from another. e.g., "all those shapes are triangles, but these are equilateral, those are isosceles, and those are scalene!"

4. Concepts: being able to apply generalizations and discriminations in order to provide definitions of groups of previously known stimuli. e.g., "All triangles are bidimensional shapes with three sides"

5. Principles: establishing relations between two or more concepts, often describing predictable results. e.g., "The triangle's type depends on the size of its sides: equilateral triangles have three identical sides, while isosceles have two identical sides, and scalenes have no identical sides!"

6. Problem-Solving: the capacity to apply principles in specific contexts in order to achieve a previously established goal. e.g., "To form a square using

\footnotetext{
${ }^{37}$ Gagné's model originally consists of 9 steps, but three of them are related to reinforcements of previous activities, not to new cognitive developments. For this reason, they were not considered, since the process of learning the game does not follow the same scope of in-class exercises which is characteristic of his analysis.
} 
two triangles, I must use two scalene triangles of the same size, joining them on the unequal side. This way, the two sets of identical sides will compose the square's four sides, while the two remaining sides will be the square's diagonal!

When applied to games - poker, for instance - stimuli would be equivalent to each card's suit and the alphanumeric symbols written on them; while chains would be the comprehension of each card's combination of suit and symbol. Discriminations would be equivalent to understanding the similarities and differences between cards of the same suit, but different symbols - and vice-versa. Concepts would be equivalent to understanding that many cards with the same number may form a pair, three of a kind, or four of a kind, while the combination of cards of the same suit may form a flush.

However, principles demand the perception that any card, by containing both a symbol and a suit, can be part of different combinations of cards, depending on the other four cards available. Finally, a problem-solving situation would be deciding which cards from the player's hand should be traded in order to try and achieve the highest-scoring combination of cards, depending on the current state of the game.

However, it is important to notice that the process of problem-solving is not over the moment an action is taken, seen as it now counts as a new piece of experience, which may be used to re-contextualize the player's decisions on future rounds:

\footnotetext{
What results from problem-solving is a principle of a higher order, which, from now on, becomes part of the individual's framework of reference. So, when the person faces a similar type of situation again, they obtain a response much faster by evoking a previous experience, no longer treating it as a problem. Problem-solving, therefore, must be considered definitely as one of the highest forms of learning. (Gagné, 1973) ${ }^{38}$
}

\footnotetext{
${ }^{38}$ Free translation of the Portuguese version, published in 1973: "O que se resulta da resolução de problemas é um princípio de ordem superior, que, daí por diante, se torna parte do cabedal do indivíduo. Assim, quando a pessoa enfrenta novamente o mesmo tipo de situação, obtém respostas com muito maior facilidade por meio da evocação e não mais a encara como um problema. A resolução de problemas, portanto, deve ser considerada em caráter definitivo como uma das formas de aprendizagem (Gagné, 1973)."
} 
Therefore, decision-making in games can be understood as akin to the process of problem-solving described by Gagné - which is the ultimate goal of reading a rulebook - and contributes to the long term development of personal strategies. Eventually, simple in-game situations will no longer be regarded as problems to be solved, making room for more complex and contextual strategies to arise, frequently even adapting depending on the opponents.

Finally, it is important to highlight that Gagné always refers to learning situations that happen in the formal schooling system, further cementing the necessity of having a specific framework of criteria to organize rulebooks rules, if it is to achieve the same level of effectiveness.

Moving on to Rowley's model: while she was not the original person to describe it, she proposes a modern interpretation to it. The model is called "The Wisdom Hierarchy" - also known as DIKW Hierarchy - and is composed of 4 different levels: Data, Information, Knowledge, and Wisdom. Each of them represents a different stage of mental processing, in order of complexity:

\footnotetext{
Data are defined as symbols that represent properties of objects, events and their environment. They are the products of observation. But are of no use until they are in a useable (i.e. relevant) form. The difference between data and information is functional, not structural.

Information is contained in descriptions, answers to questions that begin with such words as who, what, when and how many. Information systems generate, store, retrieve and process data. Information is inferred from data.

Knowledge is know-how, and is what makes possible the transformation of information into instructions. Knowledge can be obtained either by transmission from another who has it, by instruction, or by extracting it from experience. [...]

Wisdom is the ability to increase effectiveness. Wisdom adds value, which requires the mental function that we call judgement. The ethical and aesthetic values that this implies are inherent to the actor and are unique and personal. (Rowley, 2007)
}

Therefore, data is the most basic level of symbols that can be processed, and is a result of observation. It represents the observable properties of what can be perceived without any context to it. Information, then, becomes the meaning assigned to data through context. It's the meaning of the words written on the rulebook, that must be interpreted so the rules can be learned. As for Knowledge, it is the compilation of data and information to form comprehensible thoughts and instructions, that must be applied in practice. The knowledge contained in 
rulebooks would be the answer to the following question "How do you play this game?". Finally, wisdom is the highest form of mental processing, through which knowledge must be made effective in a real situation. In games, it can be interpreted as a synonym to strategy, i.e., the decision-making process of what to do and to achieve which goal.

Those four mental processing levels can be compared to the higher levels of learning described by Gagné, namely: Concepts, Principles, and Problem Solving. In this context, a "concept" is the definition of a word, generally representing an action, object or feeling. To grasp a concept, a person would need to understand the meaning of the word that defines it, the characteristics of what it describes, as well as differentiate it from similar or opposite words, e.g., for a person to understand the concept of "circular" they would need to understand that it is a round shape, different from an oval or a square. This process makes concepts equivalent to the combination of data and information since they encompass the comprehension of the meaning and the characteristics of the objects they describe.

It is also important to note that some concepts are composed of more than one concept, such as "frisbee," that is a round object. Therefore, to understand the concept of frisbee, they would need to understand what "round" means, what "object" means, and to be able to differentiate it from similar objects, such as a plate or shield.

As for the "principle", it is the description of a situation involving basic or advanced concepts that is always applicable to anything that falls inside that category. To fully understand the principle, the person needs to understand when it is applicable or not, and to accurately predict if the principle is going to take place in different situations. Therefore, principles are equivalent to Knowledge since they represent the compilation of information in order to determine general rules and how they might apply to the real world.

To grasp the principle that "spherical objects will roll if you lightly kick them," the person would not only need to recognize that any spherical object, such as balls and some types of fruits, always roll in this situation, but also: that if 
lightly kick a box, it will not roll; if you strongly kick an object, even if it is spherical, it will likely not roll, but be thrown in the air.

Lastly, when presented with an object and asked to kick it lightly, they should be able to predict whether it is going to roll or not based on its shape. Similarly to the concepts, principles should also be divided between simple and higher ones, the latter being ones that's based on two or more other principles, such as: "even if you lightly kick an spherical object, it will not roll if it is glued to the floor."

Then, the final level of learning is the development of problem-solving abilities, which is applying the concepts and principles to real-life situations in order to achieve a particular goal or complete a particular task. This is similar to the definition of wisdom, and describes the process of analyzing the game's current stages, available options and deciding which one is the most adequate course of action to achieve the game's objective - the ultimate reward for adequately learning the game's rules.

By considering both models, while also establishing parallels between them and the process of learning a given game's rules, this dissertation proposes the following categorization for the steps of each of them, redivided into three learning phases: the apprehension phase, the comprehension phase, and the application phase. The parallels are displayed in Table 3.

During the first two phases, the player's relationship with the rulebooks contents - composed of written texts and images - is the most important aspect to be considered since they will be the source of data and information being apprehended. This usage of both written text and images together is what is called a "multimedia text," the subject of study for the area of "Multimedia Comprehension", whose name evokes an interesting take on the subject, focusing on the user's comprehension of the text - much akin to Human-Centered Design and User-Centered Design principles. 


\begin{tabular}{|l|l|l|l|}
\hline Action & Gagné & Rowley & Learning Phase \\
\hline \multirow{2}{*}{$\begin{array}{l}\text { Looking at the Rulebook's } \\
\text { Contents }\end{array}$} & Stimuli-Response & Dain & Apprehension \\
\cline { 2 - 5 } & Discrimination & Information & Comprehension \\
\hline Reading and interpreting the & Concepts & Knowledge & \\
\hline Playing the Game & Principles & Wisdom & Application \\
\hline
\end{tabular}

Table 3 - Comparison Between Gagné's Model, Rowley's Model and this dissertation's Model.

This area of study mostly aims to provide learning processes that are more significant to readers (Mayer, 2014) - which is the same goal that Gagné presents in his book (1965) - and are often explicitly focused in instructional documents by providing insight on how to combine the written text with relevant images more effectively:

People learn more deeply from words and pictures than from words alone. This assertion which can be called the multimedia principle - underlies much of the interest in multimedia learning. However, simply adding pictures to words does not guarantee an improvement in learning - that is, all multimedia presentations are not equally effective. (Mayer, 2014, 43)

In this regard, in order to design more efficient learning experiences, it is necessary to comprehend how the readers of instructional texts apprehend new content. In contrast to a great part of the late 20th-century literature about multimedia processing, Mayer proposes a new cognitive model based on the three following assumptions, whose interactions are illustrated in Figure 6.

1) The human mind is composed of two processing channels: auditory and visual. Since it varies from person to person, data collected by either of them can be translated to the other. 2) The human mind has a limited processing capacity: 


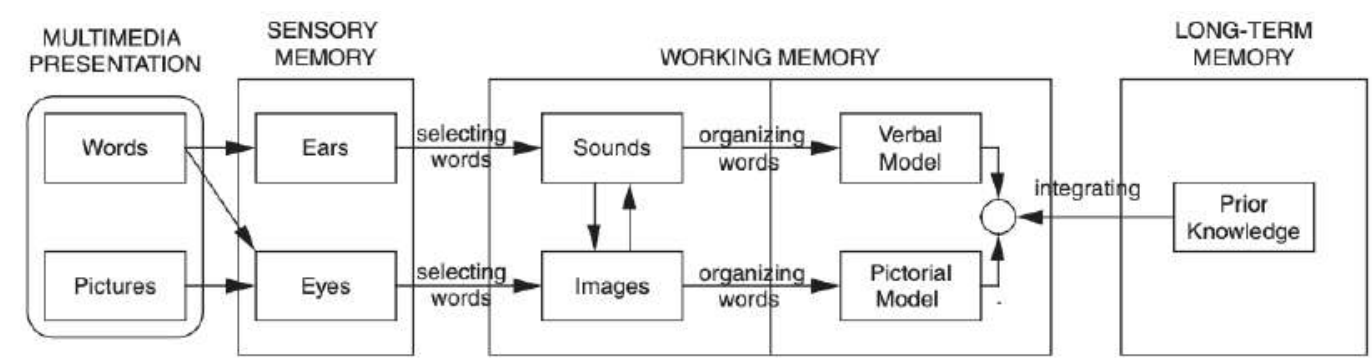

Figure 6 - Interaction model between sensory memory, working memory, and long term memory in multimedia text processing, presented by Mayer $(2014,52)$.

whenever apprehending new data and information, only part of it can be assimilated at a time, which is grouped according to the working memory's limitations. 3) The human mind has an active processing system: new data and information are compared to pre-existing memories, generating new particular meaning that varies from person to person.

Therefore, words and images are perceived through the senses of sight and hearing, while key information is channeled to the working memory and assimilated by the auditory and visual channels. In this step, it is possible for information to be translated between both channels; that is: if the player reads the word "board", they might form a mental image of a board or vice-versa.

After this exchange, words go through the second stage of assimilation, when they are sent to the verbal and pictorial models, in order to become newly constructed knowledge and, finally, be compared to previously assimilated knowledge about the subject. Therefore, Mayer proposes an incremental assimilation model of new knowledge that resembles both Rowley's and Gagné's models of cognition. By considering those similarities, this dissertation proposes a new model for interpretation, specific to the context of learning new rules about games by reading their respective rulebooks, demonstrated in Figure 7.

During the apprehension phase, players read the rulebook, exposing themselves to the visual and auditory stimuli (data) tied to the words, pictures, pictograms, and diagrams displayed on the pages. 


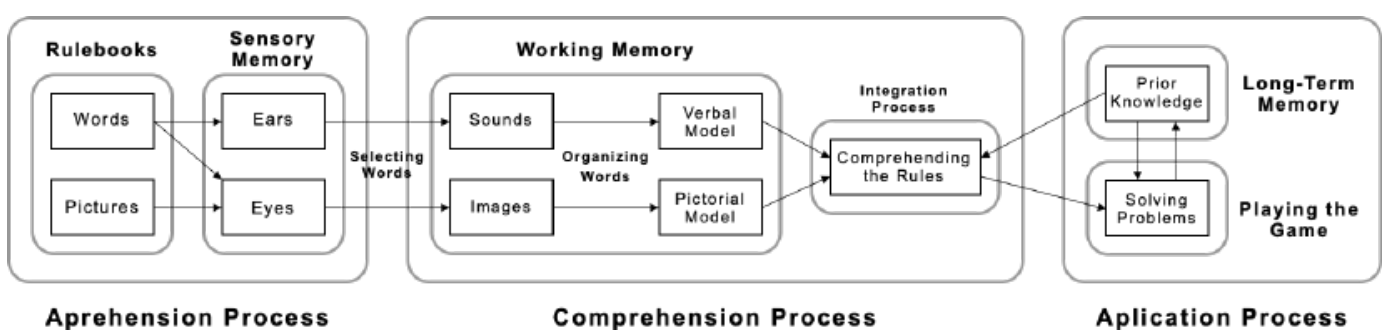

Figure 7 - Model of multimedia processing for rulebooks, proposed by this research based on Mayer's model (2014).

Moving forward, in the comprehension phase, the stimuli are translated into mental sounds and images (information) and processed by the verbal and pictorial models. Afterwards, through the comparison of newly apprehended information with previous knowledge and wisdom stored into the long-term memory, the new information is integrated in the form of concepts and principles (knowledge). During this step, players who are unfamiliar with key concepts about the game's context will most likely experience more difficulty assimilating new information. For instance, a star-wars fan who is learning a star wars-themed game will have more knowledge stored in their long-term memory to aid them during the learning process than a player who has never heard of it.

Then, in the application phase, the player's comprehension of the rules is put to test during gameplay. At this moment, players will make decisions based on their available knowledge, thus going through the problem-solving step of the process through trial and error (especially the first time they play the game). Lastly, the decision's consequences will serve as input for developing new strategies (wisdom), making players more apt to solve future, more complex problems with more ease and efficiency.

This process, described by the apprehension, comprehension and application of the rules shall be understood in this dissertation as learning. 


\title{
3.2
}

\section{Learning Curves in Tabletop Games}

Considering that the order in which information is displayed on rulebooks is somewhat deliberate, there exists an intuitive expectation that rulebooks that follow more adequate criteria will result in more efficient learning processes. In order to evaluate that, it becomes necessary to determine concrete and observable variables that will describe a learning curve.

The primary literature about the subject indicates that potential curves generally generate the best results regarding predicting productivity.

\begin{abstract}
For Blancett (2002) and Globerson \& Gold (1997), the potential curve is indisputably the learning curve model most utilized for predicting productivity. According to Globerson \& Levin (1987) and Vitr \& Gelders (2002), the curve can be utilised to describe with good precision the biggest past of tasks that are based in repetitive proceedings, besides presenting the advantage of being mathematically simple (Anzanello \& Fogliatto, 2007, $111) .{ }^{39}$
\end{abstract}

This curve is especially efficient in regards to metrics related to repetitive procedures - which initially seems to adequately describe actions taken in games: play a card; move a piece; receive a marker-point. It is important to notice that there are limitations in how applicable this literature is to tabletop games, since they are generally related to industrial engineering. All presented studies are related to the results in production lines, which result from repetitive and specific activities, not related to situations that are tied to learning a game's rules.

In this regard, learning curves tied to production lines describe the acquisition of dexterity - an ability related to the precision of movement. On the other hand, learning curves related to games' rules describe the acquisition of problem-solving abilities. Therefore, while assembly manuals present simple

\footnotetext{
${ }^{39}$ Free translation. Original text: "Para Blancett (2002) e Globerson e Gold (1997), a curva potencial é incontestavelmente o modelo de curva de aprendizado mais utilizado para previsão de produtividade. Segundo Globerson e Levin (1987) e Vits e Gelders (2002), a curva pode ser utilizada para descrever com boa precisão a maior parte das tarefas que se baseiam em procedimentos repetitivos, além de apresentar a vantagem de ser matematicamente simples" (Anzanello \& Fogliatto, 2007, 111)
} 
instructions, that must be followed to a tee, rulebooks must allow players to acquire enough knowledge to make decisions based on the game's current state.

\begin{abstract}
The optimal curve depends on what the designer is attempting to achieve with the game and different types of curves may appeal to different types of people. At one extreme, if the learning curve is steep, it implies that the player needs to spend a lot of time learning the rules of the game before he can perform to what would be considered skillful. The opposite, where the learning curve is flat, the player learns the game immediately, beating the challenges effortlessly. (Volkovas, Fairbank, Woodward, Lucas, 2019, 150)
\end{abstract}

Therefore, whenever considering learning curves that are specific to tabletop games, it is necessary to determine which variables will influence how they are measured. Using Volkovas et al (2019) as a reference, those factors seem to be tied to: 1) time spent learning the rules; 2) players ability to make skillful plays. However, their contribution ends there, since their study refers to single-player puzzle games, hence their description of the curves being influenced by players' capacity to overcome challenges effortlessly.

Considering that, in those kinds of games, each challenge can be measured by in-game parameters - time spent in each stage of the game; the percentage of players who were able to overcome each stage; etc - those factors would have to be re-evaluated in order to be applied to multi-player games. In those games, there is not a straightforward way of measuring difficulty, especially considering that:

1) For most of the time, modern tabletop games incorporate random elements: shuffling cards, randomly distributing cards, etc. Therefore, it is not simple to determine each match's difficulty, since they are all unique.

2) Even in classic tabletop games, such as chess and checkers, in which every match starts in the same exact game state, difficulty parameters would have to be measured considering the player's abilities - and, since this is one of the parameters that have to be measured, would create an unsolvable loop.

Moreover, those factors also make it more challenging to determine what should be considered a "skillful action," which is highly subjective and different for each game. Beyond that, players that are interacting with a game for the first 
time hardly ever can grasp what constitutes a skillful play for themselves, since they still do not have enough practical experience to fully understand the implications of each rule, while also not being able to forge their own strategies and comprehend their effectiveness. ${ }^{40}$

The first time you play a game, expectations should be low. The first game is like the first pancake - it can be half-cooked, malformed, and generally pales in comparison to what follows. When you play a game for the first time, you will likely have to play without being able to form a larger strategy or even fully understand the implications of the choices you are making. You may even realize late in the game that you have misunderstood the rules all along and that the entire play session was "pointless." For game players, the first game (like the first pancake) is an investment in the second one. Players put up with the clunky, slightly unpleasant first game in hopes that the later games will justify the effort. (Ham, 2016, 7)

Another contributing factor for the difficulty in defining "skillful plays" is that there are no specialists in most modern tabletop games. Unlike chess, which has been thoroughly studied for millennia, there are no books or Grand Masters

\footnotetext{
${ }^{40}$ Here, I excuse myself from the impersonal tone characteristic of my work to tell an anecdote that impacted my decision not to use "skillful plays" as a metric for measuring learning curves. Since this is a highly subjective topic of discussion, I thought best to tell the story from my perspective. Recently, one of my friends taught me how to play "Magic, The Gathering". On one of our matches, I stumbled upon a creature that costs only 2 mana to invoke and whose stats are $1 / 1$ - a weak creature with a relatively high mana cost for its stats - but with a special ability: it destroys anything it battles with, no matter the opposing creature's strength. This, basically, makes the creature an excellent tool to get rid of costly and powerful creatures, since it will deal hit-kill blows on any enemy that tries to defend its attacks. During my opponent's turn, they invoked a 1/1 creature with no special effects that could be used to fend off my creature's attack, killing it as well in return. On my next turn, I got an equipment card from my grimoire, that enhances one of my creatures by $1 / 1$, and had two creatures on my side of the field: a $2 / 2$ creature with no special effects and my $1 / 1$ killing machine. Therefore, I had two options: equip my $2 / 2$ creature with the equipment (turning it into a 3/3), attacking with both my creatures, having the opponent kill my $1 / 1$ creature but losing it's creature in the process, and dealing 3 damage to my opponent's health bar; or equipping my $1 / 1$ creature instead, not losing it in combat, but having only the capacity to do 2 damage/turn, which at first glance would delay my victory by a considerable amount of turns. I, myself, being a player who generally focuses on strategies with a long-term payoff, chose the latter, because I felt it was more advantageous for me to conserve my hit-killing creature, at the cost of 1 damage/turn. Later, the friend who was teaching me about the game commented that my choice had been a very good one, consistent with knowledgeable and strategic players, because having the possibility of eliminating a powerful creature in the future was much more valuable than dealing one extra damage/turn. They didn't have a clear metric of formula to gauge the value of each of the possibilities I had on that moment, but they had years of empiric experience and examples catalogued on their long-term memory, that gave them the tacit knowledge necessary to determine that it was the option likely to be most rewarding to me. I, for some reason, arrived at the same conclusion, even though I had virtually no previous experience with the game. Therefore, I ask myself: was I truly skillful at that moment? Was that just a stroke of luck? Had I borrowed my previous experience from games that seemed similar to that one? I don't have those answers, but I know that I lost that match.
} 
that go into detail about skillful strategies for modern games such as Frogriders, Monopoly, or War.

Therefore, instead of focusing on skillful actions, another option could be considered: its opposite. An unskilled action is much easier to define: a breach of the rules; or a mistake, i.e., an action that the player hoped would deliver a specific result but ended up resulting in something else.

By choosing this metric, it is possible to measure how well first time players have absorbed the rulebook's content by observing the number of mistakes made: players who made fewer mistakes have had a better performance than players who made more ${ }^{41}$.

However, in order to accurately measure if players made mistakes because they failed to comprehend the rulebooks contents, players must have already mastered the concepts and principles necessary to grasp how the game is played, especially the ones pertaining to mathematical abilities.

The current method to guarantee that players are apt to play games is signaling an age rating for the game, which specifies the starting age when players should be allowed to play it. However, the lack of in-depth and explicit explanations for how those age ratings are defined is much too troublesome, since it falls under the same type of problem that the rulebooks themselves present: professionals must rely on their previous experience in order to make those decisions, leaving too much room for ambiguity and dissacord.

\section{3.}

\section{Conclusions and takeaways}

In order to play any game, players must first learn how to play it. In regards to videogames, this learning process is much more intuitive, considering that there are algorithms in place that will respond to players' inputs with automatically generated outputs - which is not the same for tabletop games. However, tabletop

\footnotetext{
${ }^{41}$ This statement focuses on people who are playing for the first time because more experienced players tend to rely on their previous experience - a tendency that is explained by Mayer's conclusion that multimedia comprehension is an incremental learning process.
} 
games do not function in the same way. In order for the games to be playable, players must work together to perform the same process that a computer or machine would in video games, which requires them to be fully aware of the games' rules. In practice, this means that videogames can be learned while you play them, however tabletop games must be learned before playing it, preferably by reading their rulebooks ${ }^{42}$.

While a lot has already been said about learning processes in general, this chapter's main objective was to recontextualize them when applied to tabletop games. The first step to achieve this is answering the question: which kind of learning paradigm rulebooks fit into? Considering that games and rulebooks are mostly used outside school environments, they do not fit into the Formal learning paradigm. However, rulebooks are documents which provide a specific learning path for users, functioning much like a didactic book. For this reason, this learning process also isn't characteristic of the informal paradigm, which is marked by asystematic learning processes. In conclusion, learning how to play tabletop games by reading their respective rulebooks must be considered a non-formal learning situation, since it tends to happen in a systematic way, while not being tied to any educational institution.

The main takeaway from this conclusion is that the information contained in rulebooks must be organized in a way that makes sense - using cognitive-oriented criteria - much like any other manual, since "learning to play the game" is a goal-oriented action. However, it is important to notice that most manuals only have to instruct readers in how to perform predefined simple tasks, while a tabletop game's rulebook has to teach readers how to develop strategies of their own - a process akin to the highest levels of cognition described by Gagné (1973) - problem-solving - and Rowley (2007) - acquiring wisdom.

Moreover, by analyzing Mayer's ideas about multimedia processing (2014), it becomes apparent that reading rulebooks is an incremental learning process,

\footnotetext{
${ }^{42}$ Even considering the learn-by-playing approach - which is a common practice when learning how to play heavier and more complex games - this statement holds true. The players that are learning how to play the game will only know if what they are learning makes sense if at least part of the participants already know how to play the game. In this scenario, the more experienced players receive the burden of rulekeepers, acting in lieu of the machines in video games.
} 
which requires players to contrast the information and knowledge they are reading with their previous experiences, stored in the long-term memory, culminating in the proposal for a cognitive model of learning that is specific to tabletop games.

Furthermore, to determine which data should be measured when evaluating players performances after reading rulebooks, it was imperative to investigate the adequate literature about learning curves in games: time spent performing the relevant tasks (reading the rulebook, mitigating doubts, and playing the game) and players' aptitude with the game (calculated by the amount of mistakes made during matches).

However, considering that players' previously attained knowledge are fundamental to the process of learning and their ability to master game's rules, it becomes imperative to investigate how to determine which players are apt to play which games. Currently, this determination seems to be done via the age ratings present on game boxes. However, those ratings must also be evaluated, in order to identify if they accurately measure players' capacities. 


\section{4}

Age Ratings for Tabletop Games ${ }^{43}$

In many countries, knowing relevant information about the use of any purchased product is considered a primary consumer's right, as clearly stated in the Directive 2009/48/CE: "Warnings which determine the decision to purchase the toy, such as those specifying the minimum and maximum ages for users and the other applicable warnings set out in Annex V, shall appear on the consumer packaging or be otherwise clearly visible to the consumer before the purchase, including in cases where the purchase is made on-line." (Council of the European Union [CoEU] \& European Parliament [EP], 2009).

In Brazil, this rating is regulated by the INMETRO (Brazilian National Institute of Metrology, Standardization and Industrial Quality), which takes into account most - if not only - safety risks that these kinds of products might pose to children of certain ages. Likewise, in the European Union, the regulatory standards are similar, focusing mainly on safety hazards associated with game parts' and components' physical characteristics, such as flammability, risk of strangulation and radiation poisoning, chemical and electrical properties, and hygiene levels (CoEU \& EP, 2009).

Considering that the consumer's safety should always be a top priority, those criteria are undoubtedly indispensable to any product. However, It is also essential to bear in mind that different tabletop games have different complexity levels and thus are adequate to different target audiences. Therefore, to thoroughly address these players' needs and capacity to engage with the products being purchased, it

\footnotetext{
${ }^{43}$ This chapter was originally written as a paper for the 10th UNIDCOM/IADE International Conference Senses \& Sensibility - Lost in (G)localization. Since then, it was revised and updated, with new references also having been added. The original paper's title is: "Age Ratings for Tabletop Games' Usage in Brazil: analysis and suggestion of new criteria." (Léste, Mont'Alvão, Awaiting Publication)
} 
is necessary to not only take into consideration the children's ${ }^{44}$ age but also their stages of cognitive and social development as well.

Given this scenario, it is important to analyze different bibliographical references that may identify which cognitive criteria are essential in determining which types of games and gaming mechanics are suited for each group of children. The method is composed of two parts: first, defining a theoretical frame for analysis; then, analyzing games' current age ratings, considering the previous literature review.

For the first part, the research was based on documents and literature that could relate children's competences and cognitive skills (BNCC, 2017), which was then compared to the previously mentioned model based on Gagné's (1973), Rowley's (2007) and Mayer's (2014) ideas. By cross analyzing these references, while applying them to the process of learning any given game's rules, it was possible to identify the different topics, hierarchies and the different levels of learning those games require their players to display. Therefore, this method offers a new parameter to measure any given game's complexity, which can also be correlated to the school year in which children generally acquire the abilities that render those games adequately playable.

For the second part, considering the concepts and definitions mentioned above, an analysis of three games, with distinct age ratings, was carried out to investigate if they had - by chance or not - been adequately categorized. The results point out the first attempt to analyze the current standardization system and to suggest new criteria to be taken into account when deciding any game's age rating of usage, especially in Brazil.

\footnotetext{
${ }^{44}$ In this chapter, users are going to be referred to as "children" since tabletop games' age rating vary from $3-14+$ years.
} 


\section{1}

\section{The Current Age Rating for Tabletop Games}

When determining the age ratings for any toys and tabletop games, there are two factors to take into account, which are almost identical for Brazil and the European Union: firstly, any product - even if it is toy-like - can only be classified as a toy, and therefore marketed to children, if its age rating is set to a maximum of 13 years old. If it is targeted to an audience of 14+ years (in this case, classified as 'adults'), it is to be considered as a collectible item and subcategorized as either a model in scale; regional or decorative dolls; historical reproductions of toys; or imitations of firearms (CoEu; EP, 2009).

That causes, sometimes, games to be set for a target audience of $14+$ years for undisclosed reasons -, but also recommended for younger ages. As an example, it can be mentioned the reprinting of the game "No, Thanks": It was initially released in 2004, by the AMIGO publisher, and the original game's box informs that the game is adequate to children from "ages 8 to adult". The Brazilian reprint (which was released in March 2019) has a second age rating, that targets it to audiences of $14+-$ therefore classifying it as a collectible item, for adults, even if it does not fit the specifications. This, naturally, can be a misleading factor for possible buyers, especially for parents of children between the ages of 8 and 13, who are most likely not aware of this situation and, thus, have no way of determining if the game is really adequate for their children or not.

Secondly, when targeted to young kids, games must take into account criteria that are related to "essential safety requirements applicable to toys, including special safety requisites in a matter of physical and mechanical properties, flammability, chemical properties, electrical properties, hygiene and radioactivity." (CoEu; EP, 2009). The main point of concern, though, is that the directive is not always specific about the age range, it only describes some points of concern, as seen in the following extract: "In addition to the instructions provided for in the first subparagraph, chemical toys shall bear the following 
warning on their packaging: 'Not suitable for children under $\left(^{*}\right)$ years. For use under adult supervision;'." (CoEu; EP, 2009).

The * symbol indicates that this type of toy's adequate age of usage is to be specified by the producer, which is later confirmed: "It shall also be indicated that the toy must be kept out of the reach of children under a certain age, which shall be specified by the manufacturer." (CoEu; EP, 2009). This information raises some points of concern since there is no regulation as to how each manufacturer must determine the adequate age rating.

One of the few examples of an age range being denoted is: "The ability of the users and, where appropriate, their supervisors shall be taken into account, in particular, in the case of toys which are intended for use by children under 36 months or by other specified age groups." (CoEu; EP, 2009). This extract also highlights that cognitive skills and abilities should be considered, even if it does not further clarify how.

Comparatively, in Brazil, the standards for the games' age ratings are similar to those already mentioned, since the last INMETRO's Decree regarding this subject (2016) specifies the same criteria as the ones in the Directive 2009/48/CE, with the addition of "noise." It is also a more specific document since it explicitly states that, for instance, children under the age of 5 should not be in contact with toys that contain glass parts, since at this age they are not able to properly engage with this kind of materials without running the risk of endangering themselves. On the other hand, while it states that the toys' required abilities should be taken into consideration, it only exemplifies physical and mechanical ones, not mentioning cognitive skills whatsoever.

\section{2}

\section{Children's Expected Skills at Different Ages}

One of the few examples found that seem to incorporate a measurable and identifiable cognitive criteria were the Dark Stories games (and variations). Each version of the game contains 50 cards, each depicting a different story that the 
players must find out by asking yes-or-no questions. In the original game, all stories are about murders and, therefore it is marketed for audiences of $12+$, in compliance with the Brazilian National Department of Justice's Practical Guide for Content Rating (2018, p. 12) - which determines that detailed descriptions of deaths, including ones caused by murders, are not suited for children under the age of 12 .

Even though most versions of the game follow the same thematic trend, there are some variations - White Stories, Orange Stories and Green Stories - that depict different kinds of situations that are not connected to any deaths. Those games are marketed for ages eight and up, significantly lower than the more violent version. However, in this situations, the Practical Guide does not seem to be the only criteria taken into account, since the other age categories are "Audiences of 10+ years old" and "General Audiences," so there has to have been another factor to determine that the Age Rating would be specifically $10+$, but not any other age under 12 . The question, then, becomes: "which other criteria were considered?" However, that information does not seem to be verifiable.

One of the few examples of cognition being explicitly considered by official governmental documents when discussing the age ratings for toys was U. S. Consumer Product Safety Commission (CPSC)'s Art and Craft Safety Guide (2012), which states that "Children's behaviors and cognitive abilities may also influence their risk. For example, children under the age of 12 are less able to remember and follow complex steps for safety procedures, and are more impulsive, making them more likely to ignore safety precautions." This is a groundbreaking statement since it highlights the importance of cognitively oriented criteria in determining the age ratings for children-related activities. On the other hand, it does not offer any concrete definition of complexity, leaving it up for debate.

Some non-governmental institutions also reference this as in the following example: "From 7 to 9 years old - The ideal [toys to be played with] are thought-provoking and memory games, like puzzles and boardgames with simple rules (Proteste Association, 2007). The Proteste Association is a Latin American 
Organization that is part of the Euroconsumers Group, dedicated to defending consumer rights in many different countries worldwide. This further indicates that it is necessary to consider children's cognitive development stages when determining which toys and games are adequate to each age range. However, the brochure still does not clearly determine how rules can be classified as "simple" or otherwise, failing to establish an adequate source for regulation on the matter.

Other sources, such as the Kids Health Organization (2018), also reference boardgames as adequate for "bigger kids": "Card and board games. Card games like "war" or "crazy eights" and board games like checkers or chess teach about strategy, turn-taking, negotiating rules, and fair play. Encourage cooperation and help your child learn to manage the emotions that come with winning as well as losing." (KHO, 2018) The document also suggests that the very act of playing encourages the social-oriented cognitive development of kids, such as in dealing with losing situations - that will likely arise from inadequate age ratings.

While those documents circumscribe the scope of this chapter, not being published by Official Agencies from Brazil or the European Union, it demonstrates that the subject is already being discussed in many parts of the world - even if only on surface level - further validating the importance of conducting this kind of study.

Brazilian's "National Base for Common Curriculum" (Base Nacional Comum Curricular - BNCC) was used as a reference guide to evaluating which are the adequate abilities that children should display according to their respective school years (and age estimates). This document was chosen because its contents range from learning objectives of each school segment and child rights regarding education to specific skills to be acquired in each school year. Thus, it establishes the first frame of reference to what should be expected of each of those particular player groups.

The well-known game publisher Devir recently distributed, during academic events about games and education, two documents that discuss the concept of Game-Based Learning (GBL) and how some of the publisher's games can be used as tools to help children's development - in this case, regarding the BNCC. 
The first document, entitled "BNCC and Tabletop Games" mainly associates cognitive and social skills with games that can help children practice and develop them, and has a focus on children from Elementary and Middle School. Each page presents a specific skill and it's description according to the BNCC, as well as a list of the indicated games for that regard.

While it offers input for the usage of the BNCC as a reference to determine which games require and help children display different skills, it is essential to notice that the educational stages mentioned include children of ages between 6-11 and 11-15 years. On those age ranges, children will exhibit different stages of social and cognitive development. Therefore, since it does not specify which game is appropriate for each school year, it can only be used to determine a rough outline based on the starting years of each stage.

As for the second, entitled "Neuroeducation and Tabletop Games," there are more in-depth explanations of how each BNCC skill can be trained by playing specific games. The booklet also considers kindergarteners and high schoolers, as well as the groups mentioned in the previous document, showing a table at the end that indicates which games are more suited to each of them. However, there are mainly soft skills being discussed, and their progression is tough to assess in a theoretical frame of analysis, since they are related to psychological and social evaluations of the children's behavior. Therefore, Mathematical skills were selected to be the main focus of attention in this analysis, since they are easier to measure and evaluate.

\section{3}

\section{The BNCC and Game Requirements}

Once Math was specified as the skill being evaluated, it became necessary to choose which three specific skills could be compared between school years to result in the criteria able to adequately relate to children in different age groups. he skills chosen are part of Arithmetics, in which all are related to natural numbers, and present a progression of complexity, as shown on table 4 : 


\section{LEARNING AND DEVELOPMENT OBJECTIVES (MATH OPERATIONS)}

$1^{\text {st }}$ Grade

$4^{\text {th }}$ Grade

$6^{\text {th }}$ Grade

Utilize natural numbers as quantity and order indicators in different daily situations

Count object quantities in groups of up to 100 units and verbally produce an answer, in situations of the individual's interest, such as games and classroom Elaborate and solve problems with Elaborate and solve problems that natural numbers that involve involve calculations (mental or written, addition and subtraction, utilizing exact of approximate) with natural varying strategies, while being able numbers, through varying strategies, to estimate results with or without a calculator. content.

\section{SKILLS REQUIRED TO PLAY A GAME}

Determine the winner in a point-based Calculating additions and subtractions Calculating multiplications and divisions, game with up to 100 points between numbers on top of additions and subtractions

TYPES OF GAMES THAT REQUIRE THOSE SKILLS

Games that have a scoring system but points can be measured through counting $(1,2,3 \ldots X)$ or a scoring ruler that bypasses the need for actual calculations
Games that will require calculations, to score or $t$ count points, and does not have a scoring ruler
Games that require multiplications on the spot, usually if each kind of card/ component scores $\boldsymbol{X}$ points and lots of them can be acquired at the same time

Table 4. Comparison Between BNCC math skills, skills required to play a game, and types of games which require them. (Authors, 2019)

Afterwards, three popular games in Brazil were selected, each one fitting the type of game detailed in the bottom part of one of the three columns: For the first (1st grade), "Dr. Eureka". For the second (4th grade), "No, Thanks." For the third (6th grade), "Quartz.". It was also important to make sure that they require neither skills adequate to a higher grade than the one being evaluated, as it probably will not be part of the children's repertoire; nor from the same grade, since the children could have already mastered one of them while not having been taught the other, which could compromise the analysis.

Even if a game only requires age-appropriate mathematical skills, it is also possible for it to be too complex for children of that age. This situation could happen in games that require children to understand concepts or principles that are too complex for their age. For this reason, in order to accurately evaluate a game complexity, in addition to the BNCC skills, the Wisdom Hierarchy (Rowley, 2007) and Gagné's learning levels were also considered, aiming to establish 
criteria to analyze the complexity of games' rules. The intention was to determine what topics the children should be able to grasp in order for the game to be rendered playable.

Those criteria as less measurable in specific school years, but should offer a complementary qualitative analysis to BNCC's determination of skills for each age group, pinpointing the rating to the higher or lower age on the spectrum.

In order to contextualize the complexity factors in the games, it was necessary first to divide what the children must learn into three different categories: Game Objective (What must be achieved at the end), Tasks (How they can achieve the task); and Scoring System (How to determine if they achieved the task). Afterwards, those three categories will be dissected in the concepts, principles, and problems that ought to be understood by the game players, in the following manner:

- Three basic understandings:

- Game Objective;

- Tasks;

- Scoring System (to assess BNCC's math skills);

- $\quad$ Five more complex understandings:

- Basic Concepts - Built upon children's repertoire, outside the game;

- Advanced Concepts - When the concept is a combination of two concepts, such as an action that needs to be done to an specific object;

- Simple Principles - built upon basic and higher concepts;

- Higher Principles - built upon the simple ones;

○ Problem Solving - built upon all the others mentioned above.

All those items were then applied to three different games, each of them requiring one of the skills displayed on Table 1. If the game is deemed simple enough, the adequate age should be the lower one for the grade's general age range; if it is considered too complex, for any reason, it would fall on the higher age from the age range. 


\subsection{1 \\ Dr. Eureka}

This game (figure 5) is about a scientist that needs help completing a series of experiments by organizing different substances in test tubes. It requires the following understandings:

- Game Objective - Score the highest amount of points by collecting cards;

- Simple Task - move the balls between test tubes, without touching or dropping them, to match the picture on the card of the current round;

- Simple Scoring System (1st grade skills) - each card is worth 1 point, therefore the players need only count them and know which number is bigger to determine the winner;

- 4 Basic Concepts (Info) - Balls; Test Tubes; Card; Picture;

- 4 Advanced Concepts (Info) - Move (balls); Drop (balls); Touch (balls); Match (test tubes and pictures)

- 2 Simple Principles (Knowledge) - Balls have to be moved between test tubes to match the picture. Balls cannot be touched or dropped;

- 3 Higher Principles (Knowledge) - The first one to match the picture scores the round's point. If a player touches or drops the balls, they can't score a point during this round, even if they are the first to match the picture. If all players touch or drop their balls, the round's point is forfeited;

- 2 Problems to be Solved (Wisdom) - In which order, and between which tubes, the balls should be moved to match the picture? 


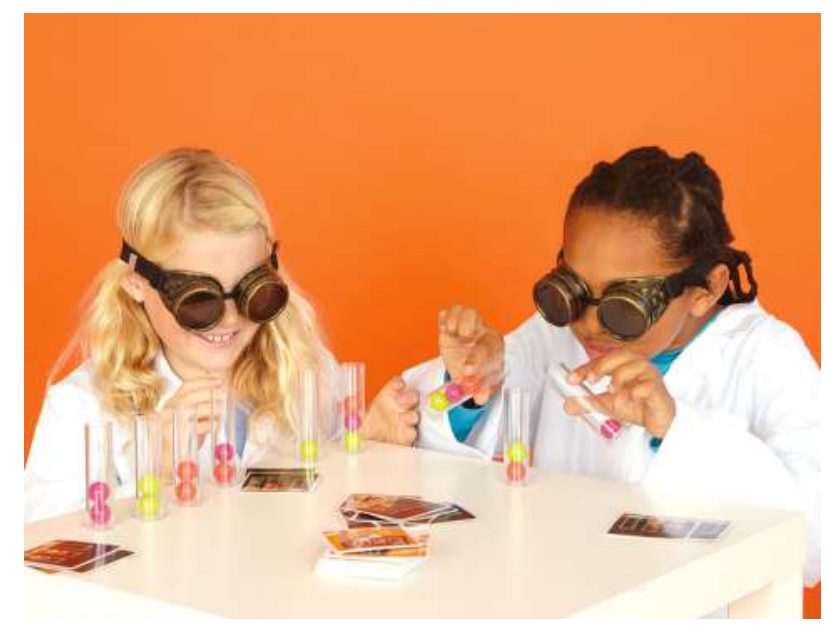

Figure 8. Dr. Eureka simulated gameplay, found on Blue Orange's official website.

Considering that this game's current age rating is $6+$, it only requires BNCC skills from the 1st grade, elementary school level (usually 6 or 7 years old children), and since it does not require lots of previous knowledge (aside from what a scientist is) to be understood, its age rating is considered 'adequately determined.'

\subsection{2}

\section{No Thanks!}

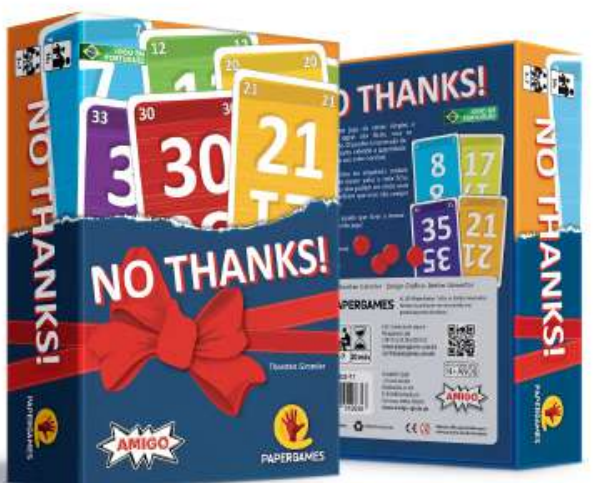

Figure 9. No Thanks product display, found on Papergames' official website. 
This card game revolves around buying ad passing cards to accumulate the least points, at the end of the game. It is primarily targeted to audiences of $8+$ and has a BGG weight score of 1.14/5. It requires the following understandings:

- $\quad$ Game Objective - Score the lowest amount of points, by avoiding getting cards;

- Simple Tasks - Place a token on the open card and passing it to the next player (or) get the card with however many tokens are on it (even if 0 );

- Moderately complex Scoring System - each card is worth the same amount of points written on it, but if any player has cards with consecutive numbers, they only score the lowest one. Add those points and then subtract the number of remaining tokens from it. The player with the lowest score wins;

- 3 Simple Concepts (Information) - Cards; Natural Numbers (3-35); Tokens;

- 2 Advanced Concepts (Information) - Get (Card); Pass (Card); Grouping (Cards);

- 4 Simple Principles (Knowledge) - A player can either pass or get a card. If a player gets a card with tokens on top of it, they also get the tokens. Cards are worth the same number that is written on them. Each token is worth 1 point, which will be subtracted from the final score at the end of the game;

- 4 Higher Principles (Knowledge) - If a player gets a card with tokens on top of it, they also get the tokens. Getting cards hinders the player's chance of winning initially. Getting cards with numbers consecutive to the ones the player has is positive. Getting tokens is positive;

- 2 Problems to be Solved (Wisdom) - When is it worth it to get a card? Is it better to get this card to place a token on it?

Considering that this game's current age rating is $8+$, and it requires BNCC skills acquired during the 4th grade, elementary school level (generally children between 9 or 10 years old) while demanding a complex decision-making process 
to determine a tasks' worth, its age rating seems to be inadequate, and should be changed to $10+$ ', to be at a safer end.

\subsection{3}

\section{Quartz}

This game (figure 10) is about dwarfs that will mine gems for five days in a row to accumulate the most wealth. It requires the following understandings:

- Game Objectives - be the richest dwarf after 5 workdays, by selling the most gems and getting coin;

- Tasks of moderate complexity - Mine a gem at random (or) activate a card targeting either yourself, a specific player or all players, as specified on the card (or) leaving the mine and collecting the next reward (and) choosing if/which gems to keep between the workdays, maximum of 2 (and) selling the rest;

- Complex Scoring System (6th-grade skill) - each precious (no unstable) gem has a specific value according to its color, for which it can be sold. You can also activate one of the following gem effects, per round: if you sell 3 of the same gems, you can double the value of another color of gems for this

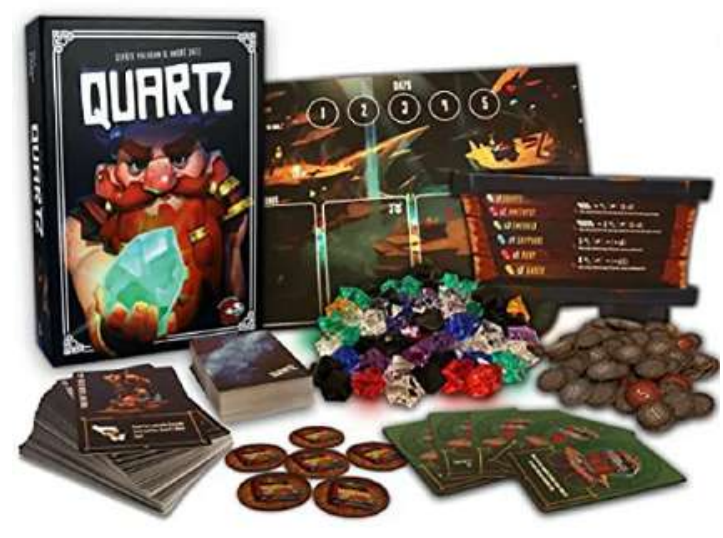

Figure 10. Quartz Box and Components, took from the copy of the game that this dissertation's author owns. 
round; if you sell 4 of the same gems, you can double the value of 2 other colors of gems for this round; if you sell a group of 5 different colored gems, you gain an additional 8 points; if you sell a group of 6 colored gems, you gain an additional 12 points. Additionally, card that remains unused are worth different values at the end (specified on the card itself), and if you have a "mining for dummies" book at the end, it is worth 3 points;

- 5 Simple Concepts (Information) - Gems; Cards; Mine (the "place"); Coins; Rewards;

- 13 Advanced Concepts (Information) - Precious (Gems); Unstable (Gems); Mine (Gems); Activate (Cards); Offensive (Cards); Defensive (Cards); Gain (Gems, Rewards) Keep (Gems); Lose (Gems); Sell (Gems); Steal (Gems); Protect (Gems); Leave (Mine);

- 4 Simple Principles (Knowledge) - During its turn, the player can choose between mining, activating a card of leaving the mine. If a player mines, they can either get a 'valuable' or an 'unstable' gem. There are neutral, offensive and defensive cards. When all players (except one) leave the mine, the workday is over;

- 5 Higher Principles (Knowledge) - If a player mines a second unstable gem, their cart explodes, and they are forced out of the mine. If a player is forced out of the mine, players do not get their bonus, which is discarded. If the player's cart explodes, they get a "mining for dummies" book, that can be used to protect against the next explosion, or sold at the end of the game for 3 coins. If a player activates an offensive card against another player, they can defend themselves (if they have an appropriate card). When all other players leave the mine, the last one is also forced out and does not get a bonus, but is the first to play in the next workday;

- 5 Problems to be Solved (Wisdom) - Which of the actions should be chosen (each turn, after each workday)? Should any gems be kept?; If so, should 1 or 2 gems be kept? If so, which gems to choose? When selling gems, if it is possible to activate a gem effect, which one should be activated? 
Considering that this game's current age rating is $14+$ and only requires BNCC skills acquired during the 6th grade, elementary school level (usually children around 11 or 12 years old), the age rating seems to be higher than necessary initially. It could also indicate that it was a business decision for the game to be sold as a collectible marketed to adults.

On the other hand, the game requires many complex cognitive processes to be made, demanding the understanding of concepts and principles outside this group's daily repertoire. It may indicate that even the game can be considered adequate considering Math skills to 11 and 12 children, there are other things to be taken into account. Therefore, the current age rating is considered to be "inadequate and should be changed to $12+$ " to be at the conservative end, since all safety regulations regarding the choking hazards that the gem miniatures might pose only concern children far too younger than 11 or 12 years old.

\section{4}

\section{Conclusions and Takeaways}

The theoretical framework proposed here sets criteria for analyzing tabletop games, relating them to the children's cognitive-oriented criteria. It was the first step to analyze if the game's age rating is adequate for children's learning and development skills.

While the current age ratings on the three selected tabletop games seem to be somewhat adequate, since it takes into account important physical and mechanical properties, it lacks further clarification about some specific aspects. Only one of the games analyzed indicates an adequate age rating, suggesting that this categorization exercise should be further applied to other games. On the other hand, it may be worth noting that, differently from the safety regulations already in effect, the inadequacies of age ratings based on cognitive criteria pose considerably fewer and lighter consequences to children - as well as other players in general. 
It is also important to keep in mind that the available documentation indicates that the very act of playing the games may be a contributing factor to children's cognitive development, which can be interpreted in two different ways: The game can be understood as an incentive to learn the necessary BNCC skills, making the child more prepared to win, which would be akin to Gagné's recommendation of contextualizing the learning objective of new school content with a real-life objective that sparks the students interest; or the process of playing the game can be understood as the very process that will result in the development of social skills, such as teamwork, coping with loss, and many others.

Therefore, the age ratings could be given as a range of the appropriate age group, instead of a singular number. This directive would allow parents and guardians to evaluate their children's capacities and learned abilities, in order to make a more accurate decision for their particular situation.

As the next steps of this approach, it would be essential to examine if these criteria can be replicated in other countries and use their laws and standards as guidelines. To achieve this, the same games should be compared to the new documents, in order to determine if the age ratings would still be the same. The results would indicate whether those age ranges vary from region to region, with two fundamental subjects being other European countries, inside and outside the European Union and the USA since they encompass the most massive tabletop games' marketplaces in the world.

It would also be interesting to test the results in practice, interviewing children of various ages that have played the games. BoardGameGeek's repository of game data already offers a tool of evaluation through which the community can vote to express their perception of the game's complexity. Curiously, Quartz has received 4 responses so far: one indicating that it should be marketed for children of $4+$ years and three for $8+$ years. While those results do not come from a large enough database to be considered significant, they may indicate that there might be other factors to be learned by actually testing the game with children, which would pose a new set of challenges by itself. 


\section{5 \\ The Informational Hierarchy of Rulebooks ${ }^{45}$}

It is commonly known among boardgame enthusiasts that the task of reading rulebooks can be blundersome - especially rulebooks for games that are particularly long. This phenomenon has been previously addressed by both professionals (Macklin, 2015) and researchers (Ham, 2016) and does not seem to be going away so soon. Despite the best efforts of some professionals of the field, such as the collaborators for the Board Game Design Lab website ${ }^{46}$ - which stores a series of articles educating people on how to properly write rulebooks -, many of the documents written and printed during the last decade still present a lot of ergonomic inadequacies, corroborating player's low expectations.

This situation came to be so dire, among other factors, because there currently are not any regulations that properly instructs rulebook writers on how to write adequate rulebooks, neither in Brazil - the country where the research for this dissertation happened - nor in the USA and EU - the biggest markets for tabletop games in the world. Consequently, those professionals have to make do with their personal experiences in writing in order to produce new rulebooks, allowing for the many discrepancies in the final results that are currently present in the market.In parallel, there is a new niche for learning how to play games that seem to be becoming more popular by the day: video tutorials, both official produced in partnership with the entreprises who develop the game - and non-official ${ }^{47}$ - produced, most of the time, by boardgame digital influencers.

\footnotetext{
${ }^{45}$ Part of this chapter was originally written as a paper for the 17th PUC-Rio/LEUI Ergodesign \& USIHC, which was then selected to be re-published in a special number of the Ergodesign \& HCI Journal. Since then, it was revised and updated, with new references also having been added. The original paper's title is: "Didactic Guidelines for Tabletop Game Manuals and Video Tutorials." (Léste, Mont'Alvão, 2019)

${ }^{46}$ Repository available at https://www.boardgamedesignlab.com/rules/\#writing.

${ }^{47}$ The term "non-official" was chosen in lieu of "amateur" because, even though not every non-official video reaches a minimum standard of quality, they are generally made by people who present themselves as professionals in the area of boardgames.
} 
Considering this scenario, it becomes imperative to conduct and comparative analysis between those documents, in order to identify if there are any characteristics of the video tutorials that would justify their steady growth in popularity and the rising number of people commiting to this area.

By choosing video tutorials that have been made in different manners and contexts, there is a variety of types of documents to analyze. These videos allow for a more thorough investigation, in order to determine which of the characteristics of the videos are positive - and, perhaps, could be incorporated into the informational project of the rulebooks.

\title{
5.1 \\ In Defense of Regulating Rulebooks
}

According to Brazillian legislation, each and every product that is sold in national territory must also contain an user handbook with didactic instructions and illustrations, adequate to the specific context in question, as stated in the CDC (Code of Consumer Defense and Protection) ${ }^{48}$

\begin{abstract}
Art. 50. Contracts warranty is complementary to legal warranty and will be made available through a written declaration. Sole paragraph. The terms of the warranty must be standardized and must make the nature of the warranty clear; what it consists of, as well as the procedure, time periods and the places for claiming the warranty, as well as any fees that must be paid by the consumer. This information must be handed to the consumer together with the instructions [of use] and installation manual and be easy to understand, with illustrations. (Brazil, 2014, 20)
\end{abstract}

While this quote makes it clear that tabletop games must be accompanied by a rulebook, it does not clarify what does "easy to understand, with illustrations" mean in practice - which is why designers, producers and editors must interpret the meaning of that in order to deliver rulebooks as they see fit. The lack of a more developed set of criteria also makes it more challenging to perceive similarities between sets of rulebooks.

In other types of products, such as food and beverages, there are strict rules in place to guarantee that all relevant information is available, namely: fabrication

\footnotetext{
${ }^{48}$ In portuguese: "Código de Defesa do Consumidor".
} 
date; expiration date; net weight; nutritional table; ingredients; allergenes; storage instructions; consumption instructions. Naturally, consumables need those kinds of information to be displayed in order to avoid serious problems, like allergies, food poisoning, exaggerated calorie intake, etc, much like ANVISA (Brazil's National Agency of Sanitary Monitoring) states: "considering that nutrition labeling makes it easier for consumers to know the nutritional properties of nourishment, contributing to their adequate consumption."49 (BRASIL, 2003)

This conclusion is further corroborated by Brazil's CDC, which guarantees "education and information about the adequate level of consumption for products and services" (Brazil, 2014), as well as

\footnotetext{
The offer and the presentation of products and services must contain information that is clear, direct, precise, comprehensive, and in the Portuguese language regarding the characteristics, qualities, quantity, composition, price, warranty, validity and origin, among other pieces of information, as well as any risks that the product or service may pose to the consumer's health and safety. (Brazil, 2014, 8)
}

Moreover, ANVISA determines how information should be displayed in food products, creating a standard of quality that protects users against inadequate labelling and misinformation. In this regard, even considering that most of the time boardgames pose minimal risks to players older than three year old children - who still face choking risks when manipulating small objects and pieces - the same standard should be applied to them.

\section{2}

\section{The Didactic and Human Factors/Ergonomics of Rulebooks}

Since reading a tabletop game's rulebook has been previously established as an educational process, other educational and instructive materials were used as an initial frame of reference for analysis, which were then re-evaluate to better fit the context of tabletop games and its rulebooks. During the years of 2019 and 2020, Brazil's Ministry of Education supervised the production of the 2020's

\footnotetext{
49 "considerando que a rotulagem nutricional facilita ao consumidor conhecer as propriedades nutricionais dos alimentos, contribuindo para um consumo adequado dos mesmos;" (Brasil, 2003).
} 
Digital Guide for the National Program of Didactic Books ${ }^{50}$ (PNLD), in which approximately 100 writers and over 20 editors took part, all from fields related to Education and other tangential areas. In this document are described the criteria for choosing new materials to be used in schools. Among them, it is worth highlighting the importance to put the content that is being learned in context:

\begin{abstract}
What is the role of schools in the present? What are the student's profiles that this school receives? What schooling is intended to be given in this school space? Preparing for the future or the present? These questions allow for varied answers, but all of them are intertwined with the urgent need to mobilize activities and methodological resources that are capable of stimulating students' interests, sharpening their creativity and promoting meaningful learning experiences. Without meaningful learning experiences, plural and contextualize, there is no possible answers for those and other questions pertaining to schools (Brasil, 2019) $)^{51}$
\end{abstract}

Despite the text being intended for the schooling system, the main point of concern presented is tying the quality of learning processes to how contextualized they are in relation to the person who is going to learn. In this regard, it is apparent that one of the main ways to enhance the learning situation's relevance is to inform beforehand how can it be applied in practice - what is it being learned for - and what impact is it going to have on that person's life:

\begin{abstract}
When starting a class, one might say "now we are going to learn about valence", which, from a motivational point of view, has no value. It would be much more advantageous for the student to be informed that valence principles would make them more apt to comprehend the molecular composition of the results of chemical reactions and to dominate other procedures that are really useful. It is evident that, for the student, the key to motivation is the conception of the action. They must want to become capable to do something (Gagné, 1965)
\end{abstract}

\footnotetext{
${ }^{50}$ In portuguese, "Programa Nacional do Livro Didático".

${ }^{51}$ Quais as finalidades da escola no presente? Qual o perfil de estudante que essa escola recebe? Qual formação se pretende dar a ele no espaço escolar? Preparar para o futuro ou para o presente? As perguntas admitem respostas variadas, mas todas elas acompanham a necessidade urgente de se mobilizar atividades e recursos metodológicos capazes de estimular o interesse do(a) estudante, de aguçar a criatividade e promover aprendizagens significativas. Sem aprendizagens significativas, plurais, contextualizadas, não há resposta possível a essas e outras questões concernentes à escola. (Ministério da Educação, 2019)

${ }^{52}$ Free translation of the portuguese version: "Ao iniciar uma aula, pode-se dizer: "Agora vamos aprender a respeito da valência", o que do ponto de vista da motivação não tem valor. Seria muito mais proveitoso que se informasse inicialmente o estudante que os princípios da valência o tornariam apto a compreender a composição molecular dos resultantes de reações químicas e a dominar alguns outros procedimentos realmente úteis. É evidente que, para o estudante, a chave para o motivo da realização é a concepção da ação. Ele deve querer tornar-se capaz de fazer alguma coisa." (Gagné, 1973)
} 
In other words, in order to provoke meaningful learning situations, there must be a clear objective. Under this paradigm, to learn is to become able to perform a new task, acquiring new skills. Therefore, two questions must be answered: First, "what are the objectives of reading rulebooks?"; second, "what are the tasks that players must be able to perform by reading rulebooks?". At first glance, both seem to have an easy - and identical - answer: winning the game. However, on second analysis, there is a much more in depth explanation for each of them.

According to Ham (2016), as mentioned in sub-chapter 3.2, players often need to play the game in order to fully understand the actions they take and the consequences they generate. It is through the practical experience that they truly comprehend what are the courses of action that will most likely lead them to victory. With that in mind, merely understanding that "the objective of the game is to win" does not seem an adequate learning objective, since it is so bland and so obvious - almost any game will have a winner - that it does not accurately relate to the specific context of the game being learned, therefore not providing a true incentive to the players.

Instead, a more accurate description of the objective would be the game-state that the winner should attain, while the tasks must describe the course of action that allows players to achieve it - defined by Quasdorf (2020) as the players' role. e.g., In Monopoly, the objective is to become the wealthiest player on the game, by performing the tasks of buying valuable properties and making smart money-related decisions; in Frogriders, the objective is to become the most successful frogrider, by achieving the tasks of hopping over other frogriders and accumulating the right kind of resources throughout the game.

Rulebooks, consequently, face the challenge of contextualizing rules by demonstrating practical scenarios, allowing users to comprehend when and how each rule applies to the game. With that in mind, it becomes important to highlight once more how the CDC states the need to use illustrations along with the text, even if the document itself does not explain how to do it. 
However, the 2018 Call for Proposals of the General Coordination for Book Programs $^{53}$ (CGPLI) states that didactic materials should use illustrations that dialogue with the text, indicating that there should be a relation of proximity between them. This argument is further sustained bu Macklin (2015), who defends that visual resources in rulebooks are tools for contextualizing the text, and Tufte (2001), who directly states that graphs, images, and tables should be as close as possible to the texts they refer to, as to not disturb the reading flow, allowing for the information to be better. According to him, sacrificing the reading flow to accommodate production specifications goes against textual usability guidelines.

Multimedia Comprehension studies also corroborate this stance, because it diminishes the process that Mayer defined as the "split attention effect":

\begin{abstract}
Based on eight studies, Mayer (2006, 2009) also found that placing text and corresponding images close to each other in a multimedia presentation (Screenshot), gave a better learning outcome than if they were separated (Cohen's $d=1.30$ ). He described his finding as the "Contiguity Principle". A possible explanation for the better learning outcome is that the integral representation may reduce the split attention effect, precisely because the visual and verbal information were integrated into each other. (Sæverot \& Torgersen, 2016, 2849).
\end{abstract}

In practice, this kind of text-image relation has been used in other types of documents, such as Duarte's Dissertation (2015), presented to the Postgraduate Program in Design of the Federal University of Paraná (UFPR). The work, titled "Distinctive Traces in Game Strategies," ${ }^{54}$ discusses frameworks on analysis for tabletop games, intending to help game designers create better games. The author also cites Tufte to justify altering the default diagramming of the document, in favour of a better reader-experience - as seen on figure 11 .

As for the rulebooks, many of them already present contextual images. However, they are more consistently present in the beginning of the rulebooks, during the set-up of the game - which, admittedly, is the part during when players are most unfamiliar with the game, therefore needing further clarification. However, many rulebooks still don't even display images of the game setup.

Other information that sometimes require further clarification are examples of actions that can be taken during the game - which sometimes are only demons-

\footnotetext{
${ }^{53}$ Edital de Convocação de 2018 da Coordenação-Geral dos Programas do Livro.

${ }^{54}$ Free translation from "Traços Distintivos de Estratégias em Jogos".
} 
STA DISSERTAÇÃo DE MESTRADO representa um marco em minha vida n E plano pessoal. Efetivamente, poder dedicar-me integralmente ao estudo dos jogos valida um interesse que me acompanha há mais de 35 anos, desde que a publicaçáo da Revista dos Jogos pela editora Abril primeiramente me mostrou a filta de fronteiras do universo lúdico (fig. 2).

Desde entảo, as exigências da vida trouxeram situaçôes de maior ou menor impacto; engajei-me em diversas profissōes e relacionamentos, constitui familia c, por vezes, fui levado ao sabor dos acontecimentos.

Mas, ao longo de todos estes anos, consegui sempre manter vivo o interesse pelos jogos e, talvez ainda mais importante, consegui despertar este interesse em outros. Pari passu, ao jogar estas obras de arte eu as estudava, embora náo de forma sistemitica.

Novas mudanças em minha vida, desta vez ao menos em parte provocadas por minha própria vontade, trouxeram-me a Curitiba, e aqui, pela primeira vez, tomei contato com estudos acadèmicos sérios sobre o tema que hả muito me fascinava. $\mathrm{O}$ próximo passo era, logicamente, engajar-me nestes estudos.

Todo este percurso deu forma a esta pesquisa, como será visto mais adiante. Mas este prefício nảo e um exercicio de reflexào pessoal. Seu propósito principal है antecipar ao leitor algumas caracteristicas pouco usuais deste texto, $e$ as razóes que me levaram a adotá-las.

\section{Um texto impessoal?}

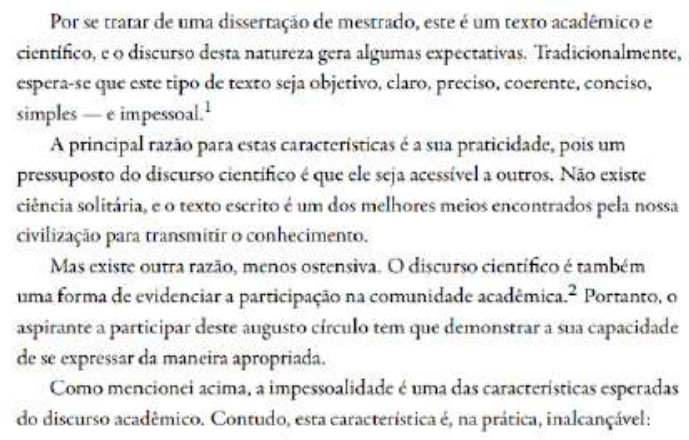

do discurso académico. Contudo, esta caracteristica é, na prática, inalcançável:

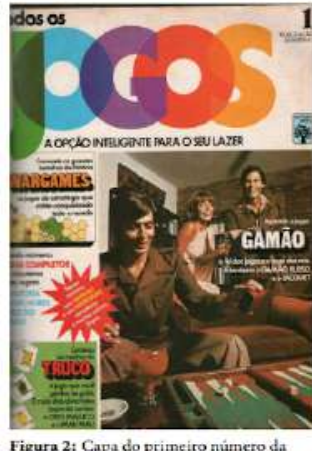

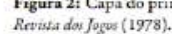

'CARIOCA (2007), "A Caracterizacío

do Discurso Académico Bascada na

Análise do Discurso:"

'AlBuquerique Bruga ef ath (2012).

- Pedindo Licença para Falar: O Sujeito

Neófito na Aceademaia":

Figure 11 - Page from Duarte's Dissertation (2015), depicting his usage of images and footnotes.

trated through written text. As indicated by the website "The Law of Game Design" (2015), conducting unassisted test ${ }^{55}$ of the game during its development will help identify which rules are harder for players to understand. Those, generally, will be the ones who will require further explanation, and therefore should warrant the usage of contextual images, next to them.

Furthermore, considering the order in which information should be organized, it becomes important to understand their context (Macklin, 2015), i.e., the category of information that should contain it. In his text, Macklin clearly and directly defines that any information should only be disclosed in a specific session

\footnotetext{
${ }^{55}$ Normally, this kind of test is referred to as "blind test". However, due to a concern about reinforcing capacitistic notions and stereotypes about visually impaired people, the term "unassisted test" was preferred, since it encompasses the main point of the test: players must interact with the game without any assistance.
} 
that is discussing that subject. e.g.: During the setup category, it does no fare to explain in detail the actions that players can take during their turns. That is not to say that, if necessary, that information cannot be mentioned, but they should be approached with care, as to not overload the player with junk information.

Moreover, Broadbent suggests that the information should be display in the temporal sequence of natural events; that is: if something happens before in the game, it should be explained before in the rulebook as well

\begin{abstract}
Understanding is better if the sequence of words in the sentence corresponds to the sequence of events in time (Clark, 1971). One can expect therefore that if the parts of some machine are encountered one after another, that it may be better for the instructions to mention first that part which is encountered first, even though this means putting the sentence in the passive. (Broadbent, 1977, 16)
\end{abstract}

The author concludes that the way sentences are written should be determined by the logical order of the events they describe, giving examples about the display of parts of a machine that a worker must learn to use. The same logic could be applied to tabletop games, suggesting that the natural order of events should be the order in which information is displayed, in order to reduce the mental workload required to understand what is being taught.

In the article "A Closer Look at the (Rule-) Books: Framings and Paratexts in Tabletop Role-playing Games" (Jara, 2011), the author explains that an essential element in the comprehension of any text are its Framings (Wolf, 2006) or Paratexts (Genette, 1997): complementary elements of the text whose raison $d^{\prime}$ etre ${ }^{56}$ is to facilitate the immersion of readers into the context of the game. They can be many and varied, such as the book cover, titles, illustrations, footnotes, commentaries and - especially - a foreword or preface. Those elements must be aligned with the reading objective, since they all contribute to the quality of the reading process (Unger, 2003) and are the gateway for the player into the context of the game, and allows for the rules to be properly understood, in order to preserve the game's integrity.

The player who trespasses against the rules or ignores them is a "spoil-sport". The spoil-sport is not the same as the false player, the cheat; for the latter pretends to be playing

\footnotetext{
56 "Reason of being" (Literal translation): philosophical or ideological calling that confers meaning to someone or something.
} 
the game and, on the face of it, still acknowledges the magic circle. It is curious to note how much more lenient society is to the cheat than to the spoil-sport. This is because the spoil-sport shatters the play-world itself. By withdrawing from the game he reveals the relativity and fragility of the play-world in which he had temporarily shut himself with others. He robs play of its illusion - a pregnant word which means literally "in-play' (from inlusio, illudere or inludere). [...]. For it, the problem of obedience and conscience is no more than fear of punishment. The spoil-sport breaks the magic world, therefore he is a coward and must be ejected. (Huizinga, 1949, 11)

When referring to the "magic circle", Huizinga is explaining how the process of suspension of disbelief is beneficial to games since it protects the internal verisimilitude of the game, that is, the play-word itself (Léste et al, 2019). The paratexts, then, offer significant contextual clues that allow players to familiarize themselves with the game whose rules they will learn. In turn, this phenomenon speaks to their motivation for learning, since it will allow them to grasp the learning objective more clearly.

Almost everyone is familiar with Monopoly, the concept of being rich, "making it big," or achieving the American Dream. However, when games revolve around a less mainstream premise, introductions are in order. Using Frogriders as an example, the players must first understand "why the hell becoming a successful frogrider is relevant to me?" Generally, rulebooks address that by introducing the fictional world where the game takes place (figure 12).

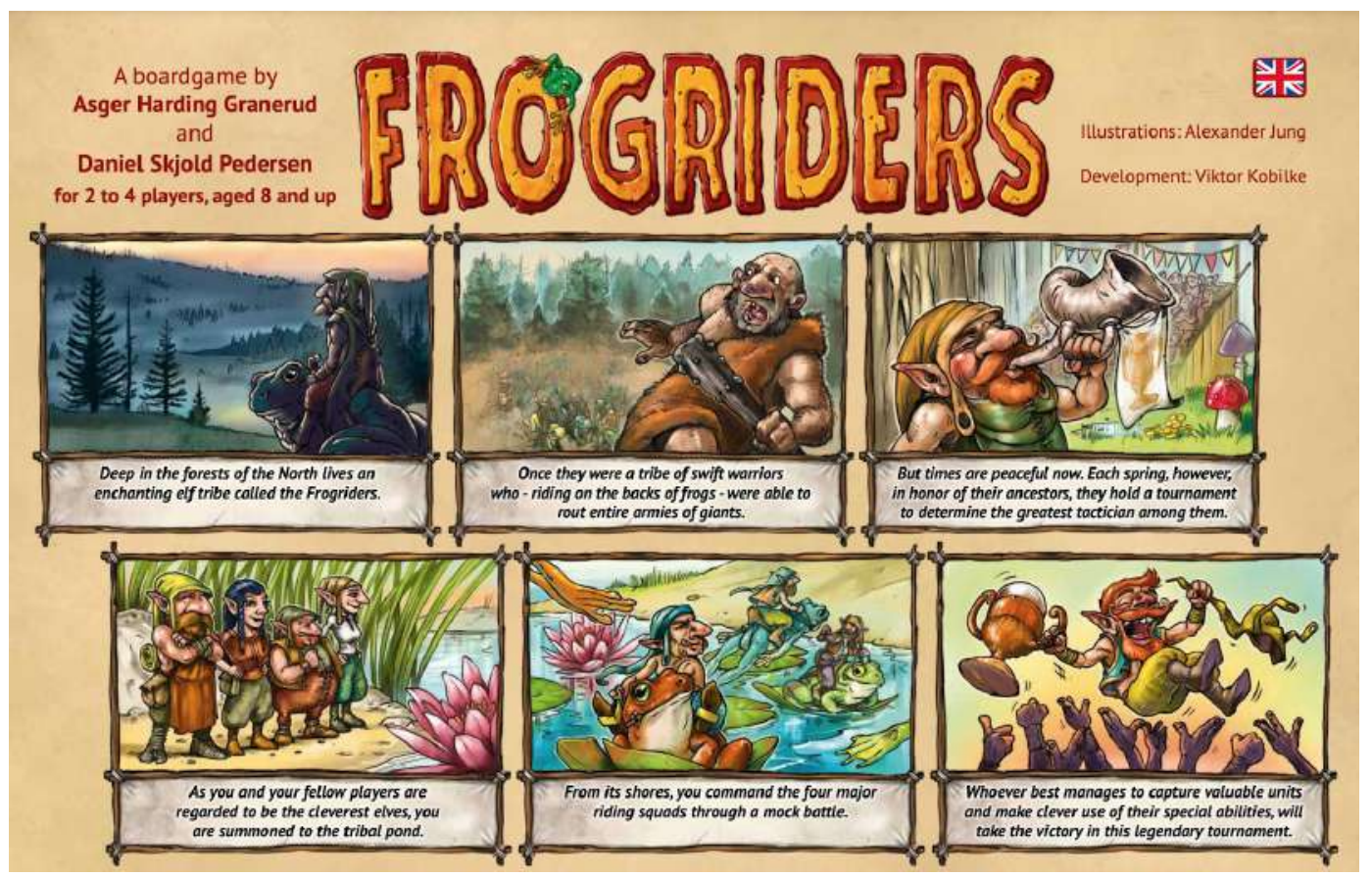

Figure 12 - Top part of the first page from Frogriders' rulebook. 
Even if the context does not directly allude to a cultural or social setting that is currently relevant for the players, they can still understand the in-universe relevance that being a successful frogrider might represent. Differently from the classroom situations that Gagné (1965) describes, the players' motivations must stem from indirect motivations, making so that those paratexts are even more critical in situations when there is not a clear tangible real-world task or goal that they might want to achieve.

According to Jara (2011), this is an even more common practice in Roleplaying Games' (RPGs) Rulebooks. His analysis indicates that this introductory element, placed before the actual explanation about the game's rules, is perceived as complementary to the game's diegesis, while it exists outside of it. Therefore, it serves the purpose of contextualizing the in-game decisions and actions, that stem from the narrative element of the game, allowing them to have real value to the players.

Another important paratext, present in considerably fewer rulebooks, is a glossary of terms. Using this contextual tactic is important in general, since there seems to be a considerable grade of confusion among light players about concepts such as "round", "turn", "match", "set", "game", their differences and similarities. Moreover, games with out-of-the-box contexts and premises also greatly benefit from glossaries, since understanding key components about the game's plot is necessary in order to properly understand the game mechanics themselves.

After consideration about the the previously mentioned authors and ideas, a set of preliminary guidelines was drafted:

1) Rulebooks must contain a contextual introduction that explains the in-universe situations that motivate players to play the game.

2) If necessary, rulebooks must contain a glossary of concepts, which should define the meaning of key concepts of the game. 
3) The first information of the rulebook's actual text must be the game objective, which should not merely be "to win the game", but should explain how - even if briefly - the game is won.

4) The rest of the rules should follow the natural course of actions that take place before, during and after the game. Generally, the first one is the game setup - which describes the game's state at the beginning of the match - and the last one is the end of the game - which describes the end-game trigger -, followed, if necessary, by scoring rules.

5) Whenever relevant, pictures, illustrations, graphs and diagrams should be used in order to further clarify the meaning of the rules. Those imagetic assets should be displayed next to the text they refer to. Generally, the rules that require the aid of images are practical examples of actions or game-scenarios, but it is crucial to test the rulebooks in order to identify other points of contingency that might require further explanation.

\section{3}

\section{Interview with Rulebook Writers}

The next step of the research was to conduct a semi-structured interview with people with previous experience in writing rulebooks for boardgames, in order to contrast the literature review previously conducted with the practical experiences of professionals of the field.

A total of 9 participants were interviewed, with the first two rounds being considered pretests. As the minimum requirement to select participants was for them to have previously worked in at least two games, in order to be able to compare at least both rulebooks, their answers were not considered for the full analysis. The original script is included in the attachment list as Appendix I, at the end of the dissertation. 
In order to invite respondents, invitations were sent to a WhatsApp group about ludic discussions, where the majority of participants are game researchers and game designers. Members of this group also referred to friends who they thought could be interested in participating. The game Designers who volunteered themselves to participate received informed consent forms that explained all their rights (Appendix II), and that they would not get any type of compensation for participating. Due to the Covid-19 Pandemic, interviews had to be held online, so the participants were allowed to choose between signing the form with an online signature or giving their informed consent via email. They were also allowed to choose between three online platforms which have built in recording tools: Discord, Skype or Zoom.

Interview Objectives: Determine the methodology used by rulebook writers to organize the information contained in them.

Target Demographic: Game designers with previous experience in writing rulebooks, even if for third-party games.

Points of Concern: Are the criteria similar to the ones described in item 5.2 of this dissertation?

\subsection{1}

\section{Questions, Objectives and Analysis}

In this part of the chapter, all the scripted questions for the interview will be presented, highlighting their goals as well as summarizing the results. The results will consider only 7 out of the 9 respondents, since they were the ones who qualified, by having previously worked in at least 2 games.

Question 1: For how long have you been working with game design and rulebooks? Do you usually perform other tasks on your projects? 


\section{Goals:}

- $\quad$ Finding out if they are knowledgeable about the field;

- Finding out if they are primarily rulebook writers or if they perform this task out of necessity;

\section{Results:}

- The seven respondents have vast experience with both game design and rulebook writing, though most of them perform the task of writing out of necessity, since they are the game designers and therefore are generally more familiar with the game and its intricacies.

- One of the two respondents who also writes rulebooks as a third party contractor indicated that game designers sometimes think they are the most qualified people to write the rulebooks. The respondent does not fully agree, since they pointed out that being familiar with the game is not necessarily the same as knowing how to better explain it.

Question 2: What do you think is the most important step in producing a tabletop game?

\section{Goals:}

- Finding out if someone considers writing the rulebook the most important part of the project;

- Finding out what constitutes important parts of the project;

\section{Results:}

- 6 out of the 7 participants were hesitant to point out a role that was more important than the others. They consider that all parts of the project are important, in their own right. However, when 
asked which one they would choose "if they had to", no one chose writing the rulebook.

- The seventh respondent considered that the role of game designer is the most crucial one, since it is the responsible for creating the game itself.

Question 3: In your opinion, is there a specific course or formation that helps people become better rulebook writers?

\section{Goals:}

- What is the perceived value of doing a course in order to become better rulebook writers?

\section{Results:}

- Responses varied significantly. Some respondents think that the skills required to be a rulebook writer are not tied to any specific course or formation, but are instead more tacit knowledge, acquired naturally through life. Upon further verification, those had degrees that were not exactly tied to the field of design, such as Engineering.

- Respondents who are designers and communicators indicated that their degrees helped them become better rulebook writers, even if the courses themselves hadn't addressed this specific task. They highlighted how graphic design, in particular, develops communication skills that are key to perform this task.

- Other respondents suspect that creative writing courses would be helpful - even if they have never enrolled in one - because they consider it important for rulebooks to be written in both an entertaining and instructional way.

Question 4: Do you believe that your degree (if there's any) helped in becoming a better rulebook writer? 


\section{Goals:}

○ Identifying if they think their degrees were useful in becoming better rulebook writers.

\section{Results:}

- All participants have a Bachelor's Degree.

- In general, they considered that their formations aided them in indirect ways, by training writing skills along the course - aside from two, who do not see any correlation between their degree and writing rulebook.

- Design, especially graphic design, was thought to have been helpful since thinking about the rulebook as a graphic document helps them write and organize the information contained in it.

\section{Question 5: Which skills do you think rulebook writers should have?}

\section{Goals:}

- Identifying which skills are deemed as necessary for a rulebook writer to have.

\section{Results:}

- The respondents did not dwell too much on that question, simply pointing out "good writing" and "the capacity to properly rank information.".

Question 6: Have you ever written the rulebook for a game that you haven't designed? If so, what inputs did you receive from the game designer? [If not, what inputs would you give to someone who is going to write the rulebook for a game that you are designing?] 


\section{Goals:}

- Understanding how is the communication between the members of a team involved in designing a game.

○ Finding out in which step of the project the rulebook is conceived.

- Finding out if rulebook writers who are not directly involved in designing the game receive a physical copy of it.

\section{Results:}

- Only two respondents have ever been outsourced to write a game's rulebook. They indicated that they require an initial document detailing the rules - even if in no particular order and a physical copy of the game, or at least a advanced prototype. They emphasized that their job is not coming up with the rules, only to write the rulebook. Therefore, the game should be in a development stage when the rules are already final.

- The other 5 respondents hypothesized that, if they needed to outsource the rulebook, they would provide an initial document with the rules and a prototype of the game.

Question 7: Generally, how's the process of writing the rulebook?

\section{Goals:}

- Investigating if all respondents face similar difficulties.

$\bigcirc \quad$ Investigating how long this process takes.

- Allowing respondents to explain in their own terms how they write the rulebook.

\section{Results:}

- Respondents indicated that two rule-related documents are written for every project: the initial document, which describes the rules, and the final one, where they are properly organized. 
- The amount of time elapsed in designing the final rulebook varied a lot between respondents, but the two respondents who write rulebooks as outsourced professionals indicated between 1 and 2 weeks, depending on the size of the game.

Question 8: In which part of the project are rulebooks generally written? Is it tested by players before being finalized?

\section{Goals:}

- Identifying whether rulebooks are written during the project or only after it is done.

○ Identifying whether they are tested or if the writer relies only on their personal experience.

\section{Results:}

- The first document is generally written while the game is being designed and was referred to as "proto-rulebook", which tends to be rewritten many times, whenever a rule is adapted or edited.

- The final document, which is the rulebook, needs to be written after the game mechanics - and, preferably, the visual components as well - are ready because it demands an extensive visual project and would therefore be much more expensive to alter, if needed.

- Respondents indicated that it is not common to test the rulebooks with potential users, but sometimes they do it on their own accord - generally asking family members or friends to read it and then play the game.

Question 9: Do you follow any criteria in order to organize the rules written in the rulebook? If yes, then what are they? 


\section{Goals:}

- Identify the current organization criteria that are applied by rulebook writers.

- Investigate whether there is already some sort of consensus in place about the subject.

\section{Results:}

- In general, the rulebooks writers with more experience have a script with personal criteria they follow whenever they need to write a new rulebook. There was a consensus that the rulebook should begin with an introduction about the game's context, corroborating the first preliminary criteria suggested on page 91 .

- Three respondents also indicated a category of information that was not previously considered: a component list - considering that after all, the game is a product being purchased and, therefore, the players need to know what are all the components included in it.

- In regards to organizing the actual rules, some respondents indicated the same technique previously suggested: the rules should follow the natural course of actions of the actual game. Others, though, indicated a different organization method: Each paragraph must explain a particular aspect of the rules, while also feeding a new piece of information. In turn, the following paragraph, in turn, must carry on the explanation of the "hook" used on the previous.

- No matter the organization technique suggested by the respondents, all 7 of them indicated the same general order for organizing the rules should start at game setup and end with the end-game trigger, followed by the scoring system, if necessary.

- When images were mentioned, they indicated that the criteria of usage was when "the text doesn't accurately reflect the rules content without ambiguity" as well as "when a situation or 
example is being described", once again corroborating the previously suggested criteria.

Question 10: What is the best rulebook you have ever written? Why?

\section{Goals:}

○ Having actual rulebooks to check for good examples.

\section{Results:}

- All respondents indicated the last rulebooks they have written as the best. They explained that, by writing more rulebooks, they are able to rethink their preferred methods and techniques, becoming more experienced in performing this task.

Question 11: What is the worst rulebook you have ever written? Why?

\section{Goals:}

○ Having actual rulebooks to check for good not-so-good examples.

- Opportunity for analyzing their chosen criteria.

\section{Results:}
All 7 respondents indicated the first rulebooks they have written as the worst. They explained that, since they had to learn how to write rulebooks on their own, their first experiences felt like more of an "experimentation".

Question 12: Do you believe that if a person was explicitly assigned to write the rulebook during each project its final result would improve?

\section{Goals:}

$\circ$ Investigate whether they consider that the activity of writing the rulebook could be assigned to a specific specialist. 


\section{Results:}

- In general, respondents considered that it would be positive to have a person to take care of this part of the project.

- One of the respondents stated that he saw no benefit to having a person solely dedicated to writing the rulebook. However, he indicated that it would be best if the person who did it was a specialist.

\subsection{2}

\section{Interview Debriefing}

Considering all the gathered responses, it becomes apparent that the preliminary criteria suggested on page 91 hold up to scrutiny compared to the practical experience of professional rulebook writers. Even if not every response corroborated every suggested criterion, enough of them did it in order for it to be considered a reliable conclusion.

Many of the respondents also pointed out how there is no guide to be followed when writing a rulebook, which creates a very steep entry barrier for new game designers and rulebook writers, who do not have any previous experience to rely on. Moreover, the absence of theoretical documents results in the development of an empirical-based culture that does not seem to incentivize research around the topic.

Some of the designers shared their scripts - with the expectation of secrecy - and, despite following the same basic logic regarding the organization of information, there is a clear stylistic distinction between the works of each one, since they are all based on personal experience. Their experiences and methods can be divided in two different groups: the first, based on the category of information itself, which means that they are more concerned about the groups of information being presented, and their relations with one another. The second, 
focuses on the information present in each paragraph, choosing to create connections between each of them in order to create a more fluid narrative.

The first group is more aligned with this research's findings. However, both options don't seem to be mutually exclusive, requiring further examination in order to identify whether they generate different kinds of results. Even so, the guidelines they presented seem to converge on a certain level, since they all indicated, for instance: the introduction of a game should be located in the beginning and the end-game trigger should be located close to the end.

However, they brought up some points of concern that were not previously thought of: firstly, the necessity of having a list of components, since the game itself is also a product, whose contents must be clearly catalogued, in order for it to comply with Brazi's CDC. Moreover, some of them indicated that, although a glossary of terms is an interesting thing to be included, they do not think that it should be displayed before the game's rules, in fear of hindering the reading flow instead of aiding it.

Some of them still pointed out that, in spite of having a script that they tend to follow, an essential part of the job of the rulebook writer is to identify to what extent the script is aiding the reading flow of players. In those situations, they must organize the rulebook's contents in other ways, which is often done through trial and error. Thus, since they have to rely on their actual experiences for guidance, that creates an incremental model of learning, much like the one described by Mayer (2014). Following this logic, the more games someone has written, the better they should be at it - which reflects their experiences.

Furthermore, the necessity of creating their own methodologies turned them into pathfinders for future writers, providing necessary input for the area of Instructional Design, which still doesn't seem to have been thoroughly addressed in the academic field either, according to them. Other areas of interest that were mentioned by them were Informational Human Factors and Ergonomics, and User-Centered Design.

In regards to the importance of each role in a game's project, it is not surprising that none of them indicated that writing the rulebook is the most important one. 


\section{4 \\ Ergonomic Criteria in Practice: an Analysis on Rulebooks and Video Tutorials}

Whenever thinking about multimedia comprehension, the relationship between text and image is key to how well interlocutors will be able to process the information contained in the documents they are interacting with. Following this logic, in order to compare Rulebooks and Video Tutorials, it is imperative to bear in mind that the type of imagetic aids that each of them use are different: Rulebooks use static images to illustrate something that is being said through text; while video tutorials create a visual narrative through video and sound - and, sometimes, complementary text.

The fact alone that video tutorials stimulate both eyes and years with data, while rulebooks only stimulate the eyes, warrants an investigation of its own. However, this dissertation's scope does not include that. On the other hand, there are many other points of attention that fall into this research's scope.

Firstly, videos are much more effective in demonstrating practical scenarios, since the visual stimuli are much more pervious throughout the document. Therefore, almost every information is translated into the visual model, since videos rarely display audible information without an image accompanying it. Since all videos analyzed are displayed on YouTube, it is important to notice that it is a platform that is constantly being improved.

In 2019, YouTube's options for indexing information in videos was practically non existent, whereas, in 2021, they incorporated many indexing options as seen in figure 13: timestamps on the description of videos that will skip it to the specific section; a display of "chapters" in a sidebar, at the top right of the screen; and the option to subdivide the video's progress bar into the different sections determined by the author. On the flipside, rulebooks' interfaces have remained practically the same, with the few advancements being about new printing technologies and writing methodologies. 


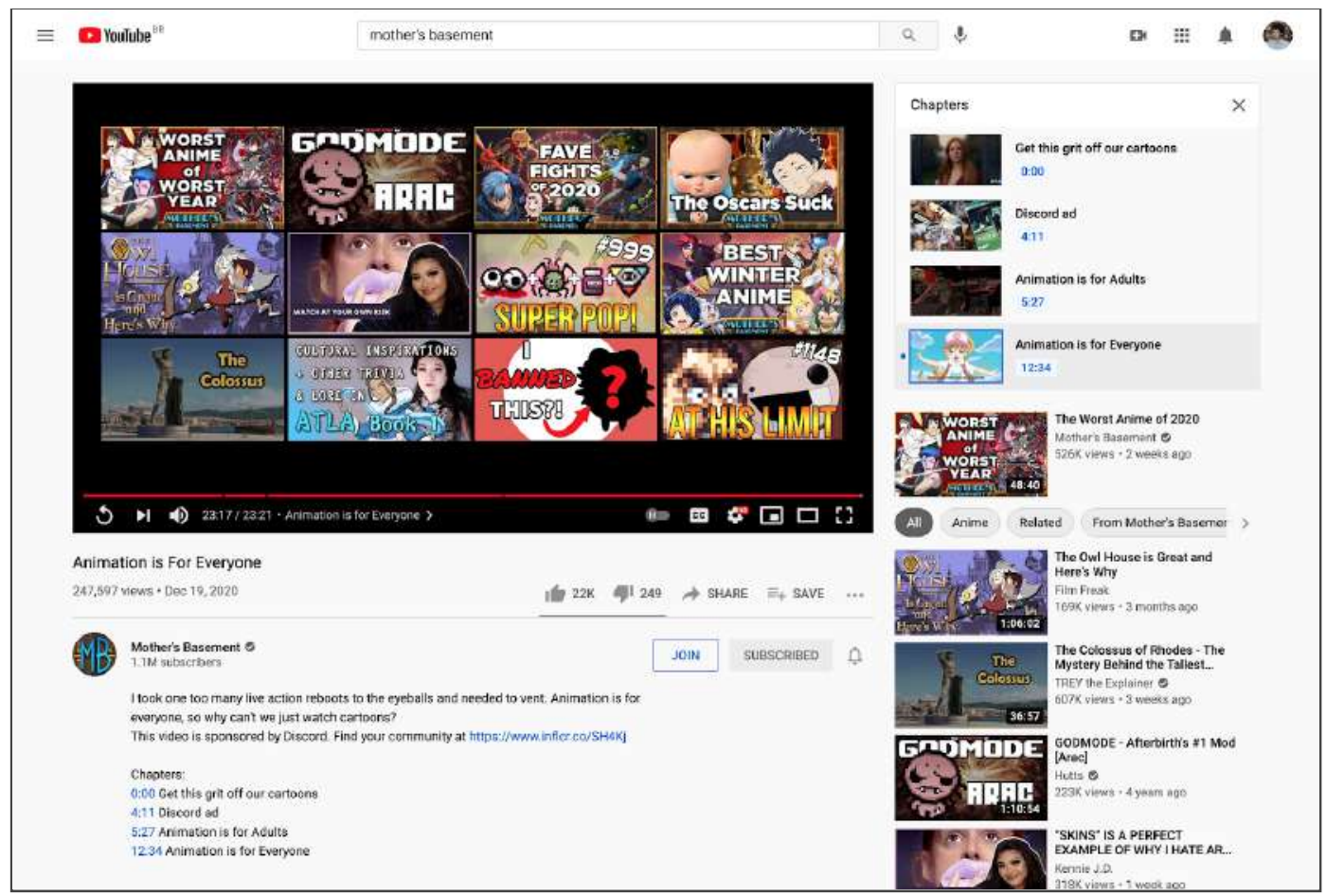

Figure 13 - Screenshot of a YouTube video page which depicts YouTube's tools of indexation.

In regards to accessibility, since videos also use auditory stimuli, they may allow for visually impaired people to interact with them with more ease - though this is only speculation. On the other hand, video tutorials require internet access, which present accessibility issues of its own, since approximately $33 \%$ of Brazilian households did not have access to the internet during the year of 2018 (CETIC, 2018).

Taking into consideration this comparative pre-analysis between rulebooks and video tutorials, three games were selected in order to be case studies, based on the following criteria: 1) Ranking of 7.0 or more by the community review in the Board Game Geek web repository of games; 2) Having been launched in the last 10 years; 3) Availability of Rulebook online, both in Portuguese and in English; 4) Availability of Video Tutorials on YouTube; 5) Representing a diverse cast of types of video tutorials. The games are: 
- $\quad \operatorname{Coup}^{57}$, a game about powerful and influential people who must cheat and bluff their way to the top, becoming the new figure head in their town ${ }^{58}$.

- BGG Community Ranking: 7.0

- Original Launch: 2012 (2014 reprinting to be launched in Brazil)

- Video-tutorials pre analysis: Many available non-official video tutorials, each of them explaining the whole game.

- Nemesis, a game about a group of astronauts who must defend their alien-infested spaceship in order to remain alive, while keeping an eye out for traitorous members of the crew.

- BGG Community Ranking: 8.4

- Original Launch: 2018

- Video-tutorials pre-analysis: A single existing video tutorial - made in partnership between the company that produced the game and a previously existing YouTube channel - teaching the whole game in about 50 minutes.

- Santorini, a game about Greek gods who use artisans as their pawns in order to conquer the city of Santorini.

- BGG Community Ranking: 7.5

- Original Launch: 2016

- Video-tutorials pre-analysis: There are many available official video tutorials, each of them explaining a small part of the game, which seem to stem from the game's business model that consists in crowdfunding new game expansions now and again.

\footnotetext{
${ }^{57}$ Versão reduzida de Coup d'État, do francês, que traduzido para o português significa "Golpe de Estado" - conceito no qual a premissa do jogo se baseia.

${ }^{58}$ The game's theme is different from each version, normally varying from country to country.
} 


\title{
5.4.1 \\ Coup - La Mame Games and Mandala Jogos
}

Coup is a top-rated game that has been first released in 2012. While the game itself is the same for both the Portuguese and English versions, and all categories of information are presented in the same order, each version of the game has its own aesthetic - and the context of the game changes with it.

\begin{abstract}
In the not too distant future, the government is run for profit by a new "royal class" of multinational CEOs. Their greed and absolute control of the economy has reduced all but a privileged few to lives of poverty and desperation. Out of the oppressed masses rose The Resistance, an underground organization focused on overthrowing these powerful rulers. The valiant efforts of The Resistance have created discord, intrigue and weakness in the political courts of the noveau royal, bringing the government to brink of collapse. But for you, a powerful government official, this is your opportunity to manipulate, bribe and bluff your way into absolute power. To be successful, you must destroy the influence of your rivals and drive them into exile. In these turbulent times there is only room for one to survive (Tahta \& La Mame Games, 2012, 1)
\end{abstract}

You are the boss of a family in an Italian city-state that is run by a corrupt and weak court, full of intrigue. You are trying to run the city through manipulation, bluffs and bribes in order to get to the top. Your objective is to destroy all other families' influences, forcing them into exile. Only one family will survive ${ }^{59}$. (Mandala, 2014, 1)

Due to its popularity, lots of video tutorials have been made about it. The ones analyzed were part of the first results for "Coup - Video Tutorial" on YouTube. This choice was made considering that, if the YouTube platform itself hosts the videos, their parameters for ranking which video is more relevant should be the ones used in this research since they represent the results that regular players would find when looking for video tutorials about the game in question. Sadly, many of them do not have any technical rigor, making mistakes about some rules - or forgetting others altogether. In some of them, part of the time is dedicated to jokes and off-topic commentaries. Oftentimes, the gameplay time far outweighed the time spent teaching the rules - which is neither good nor bad on its own accord.

\footnotetext{
${ }^{59}$ Free translation. Original text: "Você é chefe de uma família em uma cidade-estado italiana administrada por uma corte fraca, corrupta e repleta de intrigas. Você está tentando controlar a cidade através de manipulação, blefe e suborno para chegar ao poder. Seu objetivo é destruir a influência de todas as outras famílias, forçando-as ao exílio. Apenas uma família sobreviverá."
} 
Among all of them, the video from Romir Playhouse was by far the most technical in its approach, aside from being the only one with any attempt for indexation - even if rudimentary, only having "introduction," "rules," and "conclusion" sections. On top of that Romir was the only one who has not made any mistakes in his explanation. The kind of approach characteristic of all the videos - aside from Romir's - and the presence of any mistake at all seem to stem from those channel's intentions of being primarily a source of entertaining content, not technical ones. On top of that, they produced their videos independently, so they were not exposed to the same level of scrutiny that the rulebooks underwent.

The rulebooks themselves do not have any type of indexation, although the small number of pages (8) does not seem to warrant it in most cases. Coup also displays many of its rules on separate rulebooks, since most of them are related to expansions. Even in the Brazillian version, which was released together with the expansion, the choice was to separate each part of the game, generating two separate documents, as shown in figure 14. This situation makes the information decentralized, which can be confusing for some users, who might not be able to refer to the correct document on the first try. However, the game also contains individual player aids, which summarizes the most important information, so that players do not need to refer as much to the rulebook.

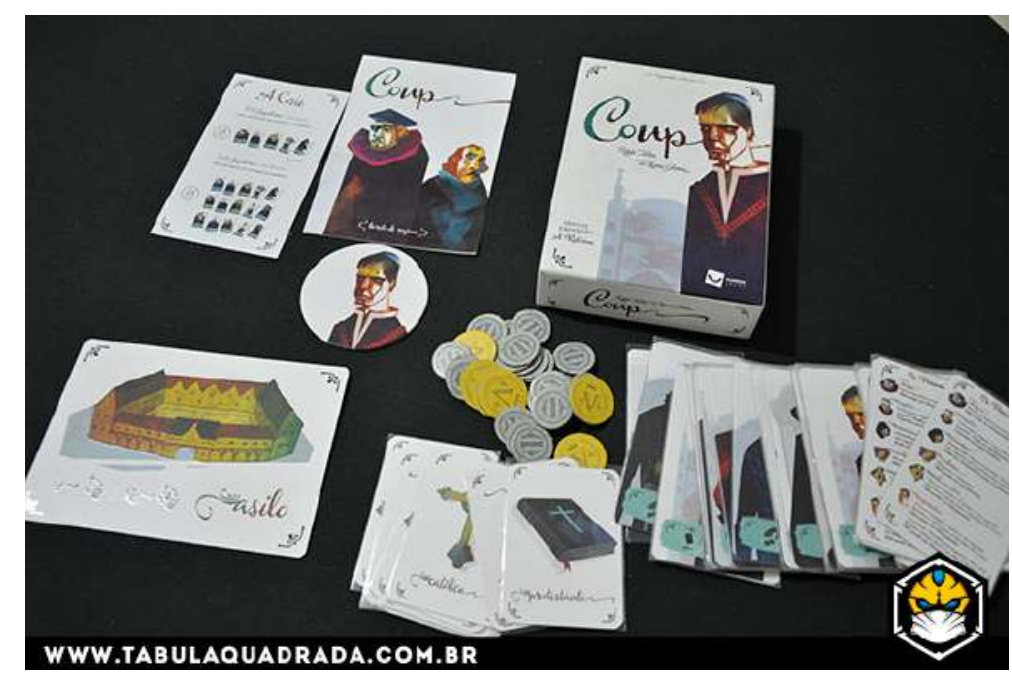

Figure 14 - Brazillian Coup's components, following western patterns of reading: "The court" rulebook, Primary Rulebook, game box, Asylum card/rulebook, game chips, religion cards, character cards, and player aids. 
When concerning the order in which information is displayed and the usage of illustrations, neither rulebook fully complied with the suggested criteria. Aside from not presenting the game objective before the setup, the only images present on the rulebook are illustrations of each character card - which are also present on the cards themselves - as seen on figure 15. On top of that, some of the rules might qualify for a glossary, since they just explain the meaning of certain terms when used in the context of the game, such as "influence".

Taking the previous comments into consideration, it was necessary to compare the organisation of information on each of the documents. This comparison was made through table 5, which highlights the order in which each group of information was displayed on the rulebooks. The table also contains technical information about each document, namely: language in which it was written; presence/absence of indexation; length (in pages or minutes and seconds); the type of document (official or non-official); and the type of discourse (technical, oppinative or both).
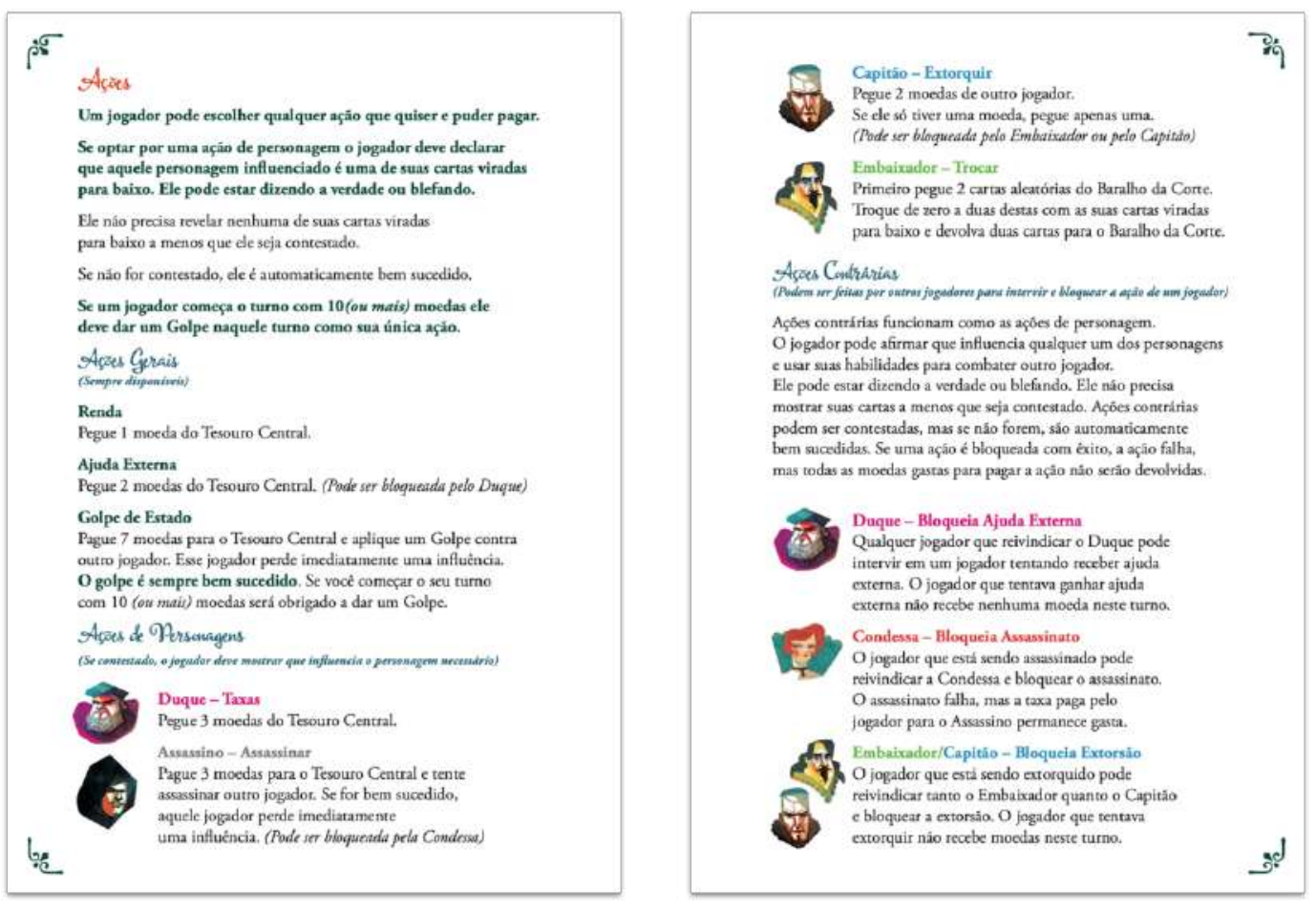

Figure 15 - Excerpt from Brazilian Coup 's Rulebook, showing the only illustrations present in it. The image is available in the online repository "Ludopédia". 


\begin{tabular}{|c|c|c|c|c|c|c|c|c|c|c|}
\hline \multicolumn{4}{|c|}{ Rulebooks } & & \multicolumn{6}{|c|}{ Video Tutorisis } \\
\hline Main Rulobook & Payser Aid & Exparstion Card & Coun Sheot & Docaurront's Name & Fasaces Studart" & Jack Explicador" & Jogando Omine" & Ronit Playhouse & Geek BSLundry & Polypon \\
\hline \multicolumn{11}{|c|}{ Teetnieal Sheat } \\
\hline Portuguese & Partugueses & Partuguese & Partuguose & Languaan & Portuguese & Porteguesso & Portuguese & Portiguieso & Englah & Englsh \\
\hline No Indexation & No indexation & No indexation & Na hdexation & inderation & Na indexation & No Indexation & No Indexation & Time Stamp & No indoxation & No Indexation \\
\hline 8 pages & 2 pagess & 1 page & 2 pages & Langth & $2521^{\circ}$ & $3351^{\circ}$ & $2040^{\circ}$ & $1904^{4}$ & 2507 & $3005^{\circ}$ \\
\hline Otrial & Othcial & OMicial & Oncial & Type of Dociument & Non-ontisal & Non-offoral & Nenoticial & Non-eftcial & Non-offical & Non-oficial \\
\hline Tectricical & Teetriced & Tectricial & Technikal & Disceurse & Boh & Oppinative & Oppinative & Tectinical & Bath & Bcth \\
\hline \multicolumn{11}{|c|}{ Information Ordet } \\
\hline Cover & Actons & Introductian & $3-6$ plasyers & 1 & Intreoduction & Technrical Steet & Introcuction & Introduction & Introduction & Introcustiton \\
\hline Introduction & Cofigaliary Aations & Game Selve & $\begin{array}{c}\text { Variant } 3-6 \\
\text { players }\end{array}$ & 2 & Tedtrical street & Game senup" & ame criecsive & Componteress & Carcos & Techicical Sheet \\
\hline Game Componerts & Character Actions & Cherges in ruies & $7-8$ players & 3 & Game Objective & Tums & Technical Sheet & Game Selup & Game Setup & Game Setup \\
\hline Gerre Setip & Variant: Inquasilor & Actions & $9-10$ players & 4 & Came Setup & nctons & Personal Evatuation & Gane Objective & Challongas & Cards \\
\hline Game Cojiectire & - & creds & - & 5 & Cards: & General Actions & Garne Secup" & Setup/2 & Came Objective & Character Actions \\
\hline Cards & - & - & - & 6 & Creactso Actions & Chalenges & Cards & Actions & $\begin{array}{l}\text { Examples } \\
\text { (Gemenestey) }\end{array}$ & General Adions \\
\hline Ceneral Rules & - & - & - & 7 & Acsons & Came crieceste & Accions & Ceneral Actions & General AClions & Obligatory Actions \\
\hline Actons & - & - & - & 8 & Genereal Actions: & Cheracter Actions & Cheracter Actions & Oblegatory Acfions & $n_{p s}$ & Chatenges \\
\hline Oeligatory Actions & - & - & - & 9 & Obigatcery Actions" & $3-6$ playes & Chalerges & Character Actions & - & Gome Objective \\
\hline Ceneral Actions & - & - & - & 10 & Chatenges & Cheracter Actions:2 & $\begin{array}{l}\text { Examples } \\
\text { (Gameplay) }\end{array}$ & Chalenges & - & $\begin{array}{l}\text { Examplas } \\
\text { (Gameplas) }\end{array}$ \\
\hline Character Actions & - & - & - & "1 & $\begin{array}{l}\text { Examples } \\
\text { (Gameptay) }\end{array}$ & Variant Inquisitor" & Challenges/2 & Character Actiona/2 & - & - \\
\hline Counter Adions & - & - & - & 12 & - & General Actionara & Obligatory Adtions: & $\begin{array}{l}\text { Intercictions Between } \\
\text { Pules }\end{array}$ & - & - \\
\hline Crallenges & - & - & - & 13 & - & Oeligatory Actions & Warant: inquis dor & Examples (Gomeplay) & - & - \\
\hline $\begin{array}{l}\text { Interactsons } \\
\text { Betwoen Rulas }\end{array}$ & - & - & - & ${ }^{14}$ & - & $\begin{array}{c}\text { Examples } \\
\text { (Gameplay) }\end{array}$ & Personal Evaluation & Tips & - & - \\
\hline Examples & - & - & - & 15 & - & - & - & End of the Game & - & - \\
\hline Variant 2 players & - & - & - & 16 & - & - & - & Vatiant: $7+$ players & - & - \\
\hline Variant mosessice & - & - & - & 77 & - & - & - & Parsonal Evaluation & - & - \\
\hline varient $7+$ players & - & - & - & 18 & - & - & - & Technical Sheet & - & - \\
\hline Credis & - & - & - & 10 & $=$ & - & - & - & - & - \\
\hline
\end{tabular}

Table 5 - Comparison between Coup's Rulebooks and Video Tutorials.

\section{4 .2}

\section{Nemesis - Rebel and Awakened Realms}

Considering that there is only one official video made for this game, no selection was needed. This analysis was originally done ${ }^{60}$ by comparing the video with a prototype rulebook, which was the only one available on the internet at that moment. However, due to updates into the game's crowdfunding campaign, the final version eventually became available to the public.

Even by briefly reading both documents, it becomes apparent that the testing process that the rulebook underwent was vital to determine the rulebook's quality, which improved considerably, according to the previously established criteria. One such example is the component list, as seen in figure 16, displayed on the next page.

\footnotetext{
${ }^{60}$ Proceedings of 17th Ergodesign \& USIHC, 2019.
} 

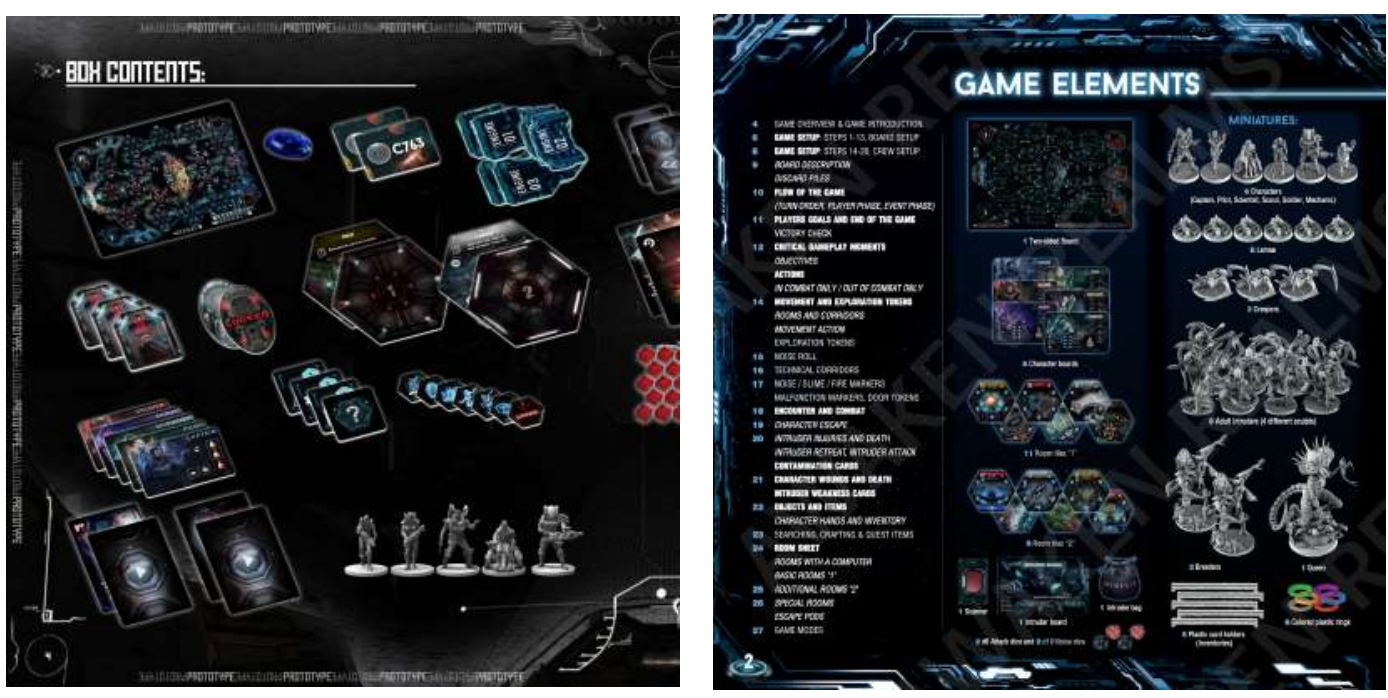

Figure 16 - Box contents from the prototype rulebook for Nemesis (Left); Game elements for the final rulebook for Nemesis (Right).

On the left, the rulebook prototype can be seen, without any textual explanation about the images presented. This lack of text hinders players' comprehension since they cannot be sure of what those components are, considering that the role of images in rulebooks is to contextualize written text (Macklin, 2015). On top of that, the objects' isometric view does not seem to be user-friendly, since it does not accurately represent how they will be arranged in real life.

On the other hand, the final version presents the complete set of components, including their names and pictures - with perspectives that are much more akin to the ones that will be seen on the game table. Another nice touch is calling the components "game elements" instead of "box components". The new label, instead of referring to physical media - the actual box - refers to the game itself, bringing up the context of use and contributing - even if in a small scale to the summoning of the magic circle (Huizinga, 1949) and to the players' immersion in the game.

As to how the rulebook's contents are organized, the order is the same in both of them, except for the objective of the game, which is inadequate on both versions: on the prototype, it appears after game setup; while in the final version it appears after the explanation of how turns work. This choice is mostly inadequate 
in this game, since the game setup requires players to choose between character cards they will have to use throughout the game, among other things - which requires them to fully understand what they must become able to achieve by the end of the game. Some other categories had their names changed, which is not unusual, since many rules are revised, updated and rebalanced during the testing phase of a game's project.

The video, produced by the channel Board Game Replay, ${ }^{61}$ only displays images about the boardgame's content. When human figures are present, only their hands appear on-screen, always directly interacting with games components, therefore exemplifying specifically how the game is played - even if some of them have distinctive features, such as rings, which might be distracting for some players. In comparison to other videos from the same channel, there is a clear distinction in stylistic choices, especially regarding scene framings and the discourse being used to explain the rules. While the other videos focus on gameplays, much like those evaluated for subchapter 5.4.1, this one focuses on teaching how the game works, using a much more technical language, probably because it was done in partnership with the company that produced Nemesis (figure 17).

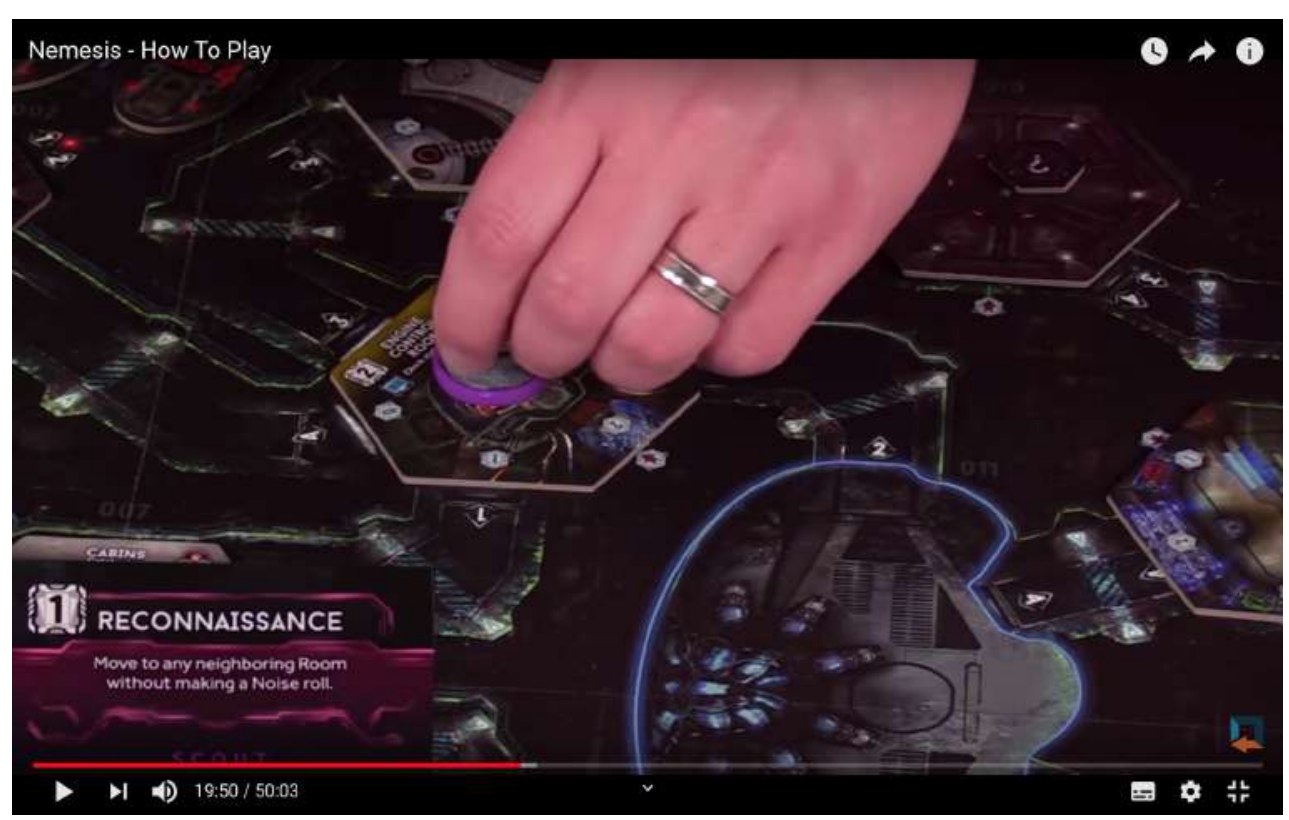

Figure 17 - Frame from the video tutorial for the game Nemesis, available on YouTube.

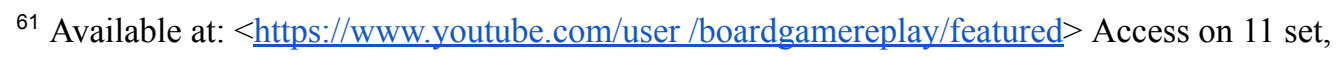
2019.
} 
The technical approach displayed on the video serves to characterize it as a much more viable candidate for being used as an exemplary case or model for future videos, especially because it displays a clear indexation of the information contained in it, making it easier for players to navigate it, as shown in figure 18 . The display of human figures in the context of use also mimics the actions that players will make throughout the game, fulfilling the role that computers would have in video games (Léste et al., 2019), and depicting examples of gameplay, without involving social interactions between guests, which seems to be a central point of interest for non-official videos.

The comparison between the three documents is shown next, on table 6:

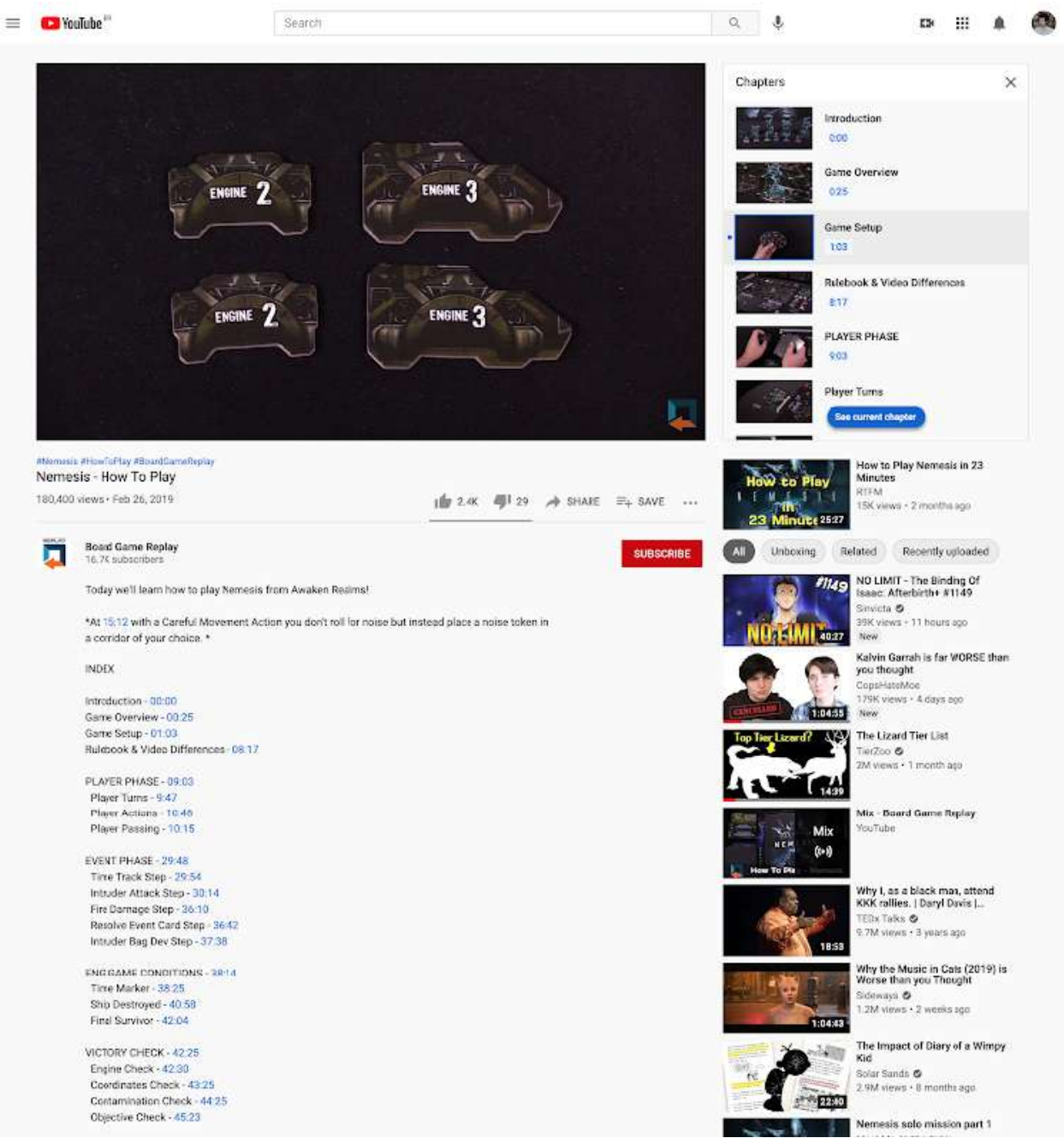

Figure 18 - Snapshot from the YouTube Page where the video tutorial for the game Nemesis is displayed, containing its index. 


\begin{tabular}{|c|c|c|c|c|c|c|}
\hline \multicolumn{4}{|c|}{ Rulebooks } & \multirow{2}{*}{ Document's name } & \multirow{2}{*}{\multicolumn{2}{|c|}{$\begin{array}{c}\text { Video Tutorial } \\
\text { Nemesis - How To Play }\end{array}$}} \\
\hline \multicolumn{2}{|c|}{ Manual Principal - Protótipo } & \multicolumn{2}{|c|}{ Manual Principal - Final } & & & \\
\hline \multicolumn{7}{|c|}{ Technical Sheet } \\
\hline \multicolumn{2}{|c|}{ English } & \multicolumn{2}{|c|}{ English } & Language & \multicolumn{2}{|c|}{ English } \\
\hline \multicolumn{2}{|c|}{ No indexation } & \multicolumn{2}{|c|}{ Summary } & Indexation & \multicolumn{2}{|c|}{ Time Stamps } \\
\hline \multicolumn{2}{|c|}{24 pages (4 blank) } & \multicolumn{2}{|c|}{28 pages } & length & \multicolumn{2}{|c|}{$50^{\circ} 03^{\prime \prime}$} \\
\hline \multicolumn{2}{|c|}{ Official } & \multicolumn{2}{|c|}{ Official } & Type of Document & \multicolumn{2}{|c|}{ Official } \\
\hline \multicolumn{2}{|c|}{ Technical } & \multicolumn{2}{|c|}{ Technical } & Type of Language & \multicolumn{2}{|c|}{ Technical } \\
\hline \multicolumn{7}{|c|}{ Information Order } \\
\hline Cover & Game Components & Cover & Index & $1-2$ & Introduction & Game Setup \\
\hline Game Setup & Game Objective & Game Components & Overview & $3-4$ & Glossary & Player Phase \\
\hline Turns & Player Phase & Credits & Author's notes & $5-6$ & Player Turns & Player Action \\
\hline Basic Actions & Special Actions & Introduction & Game Setup & $7-8$ & Passing your tum & Events \\
\hline Room Actions & Exploration Phase & Turn Order & Player Phase & $9-10$ & Time zones & Intruder Attack \\
\hline Noise Rolls & Intruders & Event Phase & Game Objective & $11-12$ & Damage by fire & Solving Event Cards \\
\hline Events & General Rules & Endgame triggers & Mais Events & $13-14$ & Developing intruders & Endgame Scenarios \\
\hline Doors & Repairs & Individutial Objectives & Actions & $15-16$ & Marking Time & Ship Destruction \\
\hline Attacking Players & Endgame & Movement and Exploring & Encounters and Combat & $17-18$ & Last Survivor & Win conditions \\
\hline - & - & Objects and Items & Detailing Rooms & $19-20$ & Checking the Engine & Checking Coordinates \\
\hline - & - & Game Modes & Appendix: player aid & $21-22$ & Checking Contamination & Checking Objectives \\
\hline
\end{tabular}

Table 6 - Comparison Between Video Tutorials and Rulebooks for Nemesis.

\subsection{3}

\section{Santorini - Spin Master, Roxley and Galápagos Jogos}

In order to conduct Santorini's evaluation, the most recent versions of the Portuguese and English version of the rulebook were analyzed, as well as a total of seven videos: The original kickstarter campaign, where the game rules are explained; The golden fleece expansion (unavailable in Brazil); and other 5 for God Cards, each one representative of the five categories of available God Cards.

Santorini's videos were produced by an official partner of the original publisher in their YouTube channel. Despite that, they seem to lack basic information that is critical for understanding how the game works, e.g.: on the rulebooks, on top of each god card's explanation, small pictograms are used to indicate in which situations those cards can be used, as seen in Figure 19: two human busts for 2-player games; three human busts for 3-player games; four humans busts for 4-player games; a small goat head for the golden fleece expansion. On the other hand, inte videos, only the explanation of how the cards 
work is present, making it so that the rulebook would be necessary in order for players to fully comprehend when they can or cannot use the cards.

Furthermore, the video that explains the basic mechanics of the game is titled after the original Kickstarter Campaign, with no mention of the game's rules. Moreover, the explanation takes about 30 seconds, with the other 5 minutes being about the campaign itself - which, while providing some context about the game, does focus on out-of-game elements, instead of in-game ones, not contributing to players' immersion.

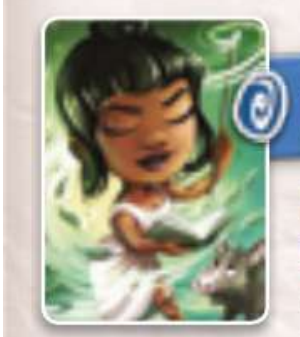

17. Circe

Feiticeira divina

Início do seu turno: se os Trabalhadores de um oponente não forem vizinhos um do outro, você, sozinho, usará o poder da carta deles até seu próximo turno.

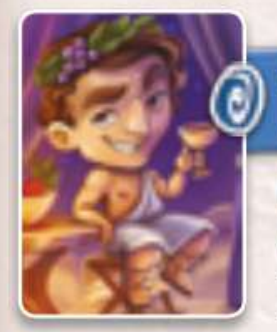

$228 \quad 2228$

$\underline{\underline{\underline{P}}}$

18. Dionisio

Deus do vinho

Sua construção: sempre que um

Trabalhador que você controla criar uma

Torre Completa, você pode jogar um

turno adicional usando o Trabalhador de um oponente em vez de um dos seus. Nenhum jogador pode ganhar durante esses turnos adicionais.

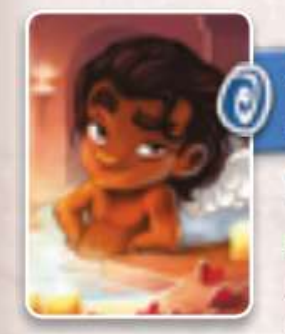

$228 \quad 2822$

19. Eros

\section{Deus do desejo}

Preparação: coloque seus Trabalhadores em qualquer lugar ao longo de bordas opostas do tabuleiro.

Condição da vitória: você também ganha se um dos seus trabalhadores se mover para um espaço vizinho do seu outro Trabalhador e ambos estiverem no topo de blocos de Nível 1 (ou no mesmo nível de altura em uma partida de três jogadores).

Figure 19 - Excerpt from Santorini's Rulebook, depicting God Cards and the contexts when they can be used. 
Regarding the rulebook, the front page (figure 20) does not present any contextual information about the game, instead referring to a website as the first textual information, in case the player "needs help" - which redirects them to a website with all the video tutorials. However, the rest of the content is in an adequate order, even adequately using images in order to further explain practical situations that normally occur during the game.

However, the other pages do not present the same level of in-depth imagery, instead following the example of Coup's manuals: only using illustrations to highlight the physical appearance of the game's characters, as shown in figure 21 .

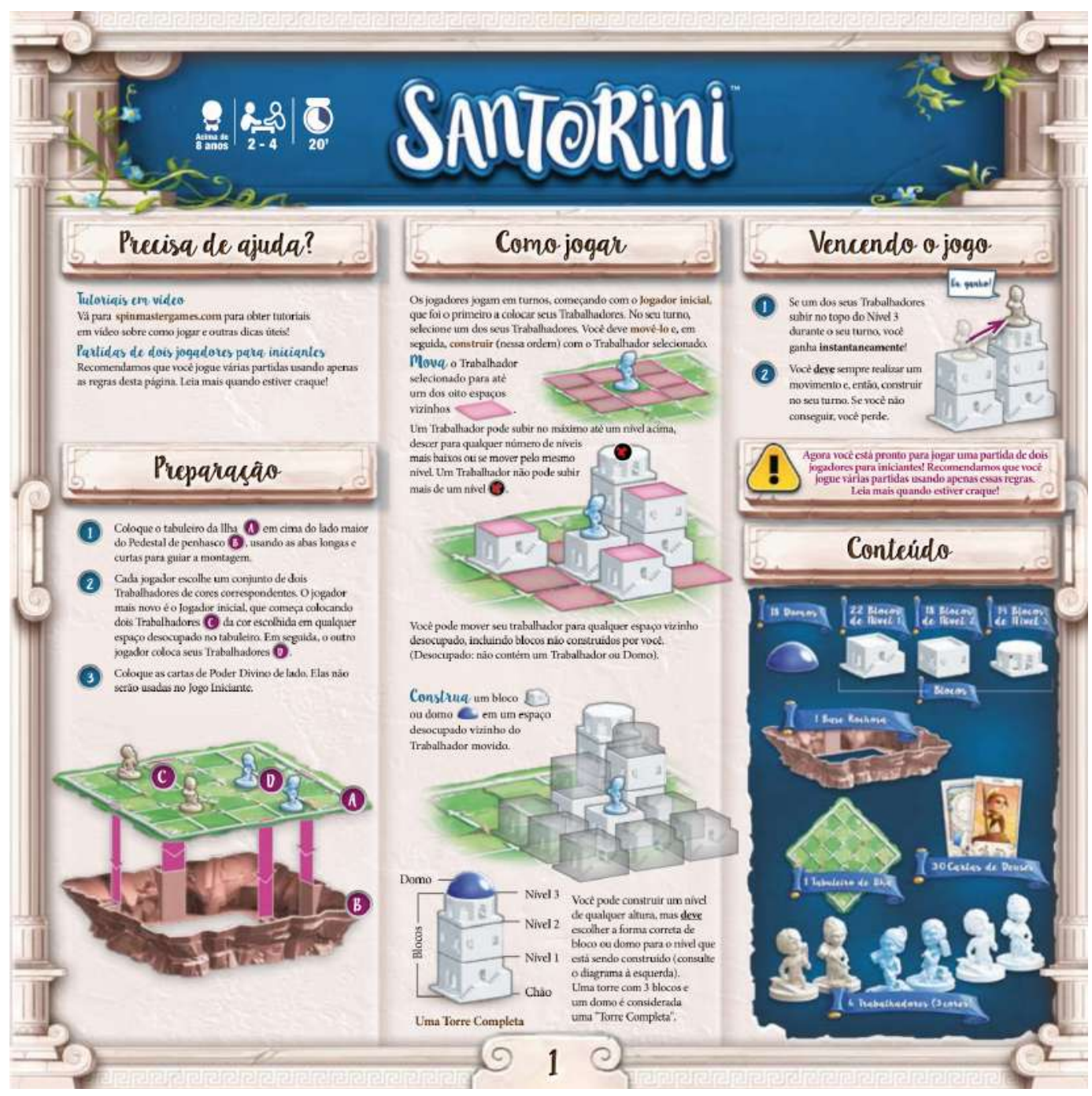

Figure 20 - Page 1 of Santorini's rulebook. 


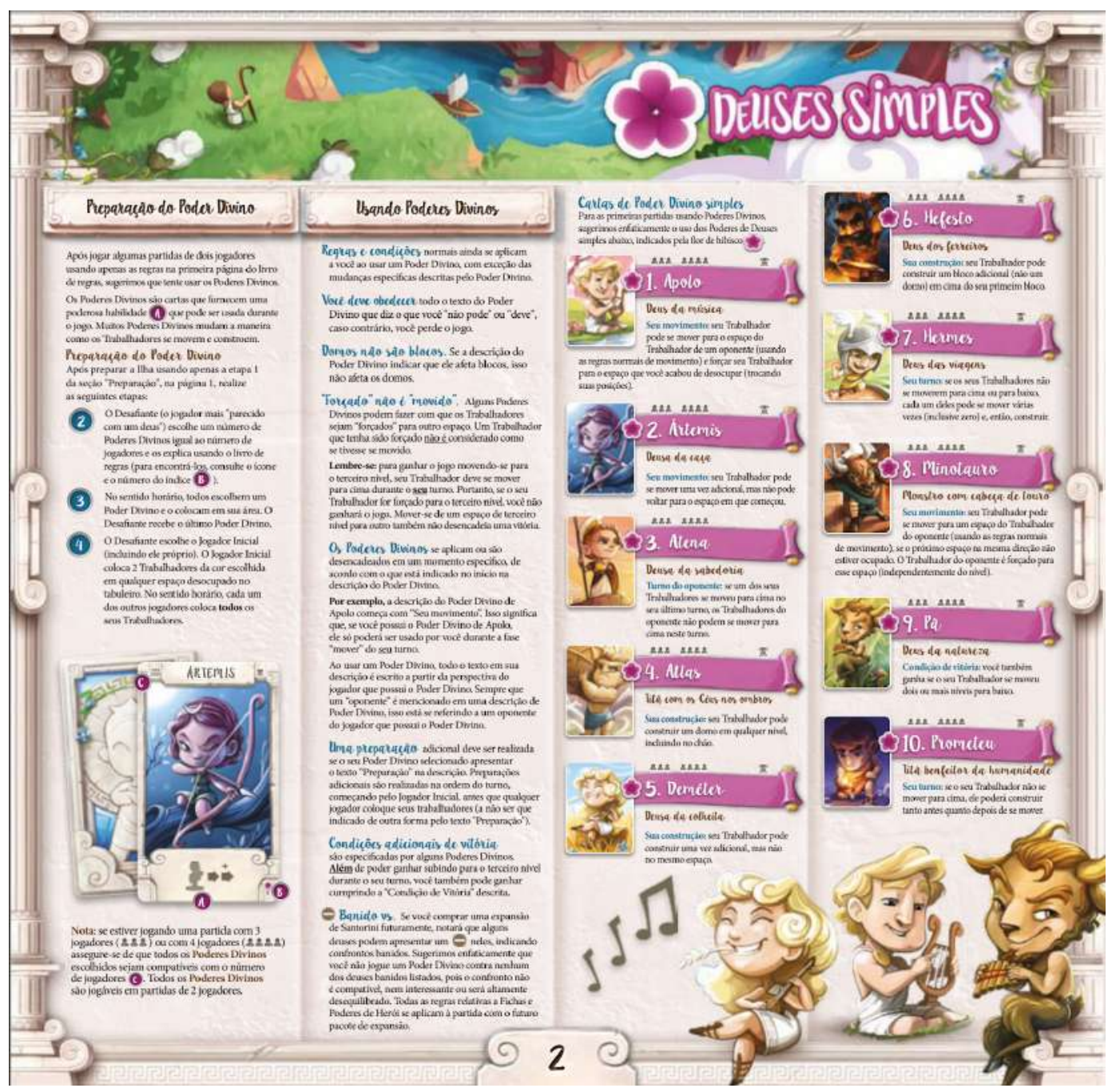

Figure 21 - Page 2 from Santorini's Rulebook.

In regards to the use of images, the video tutorials follow (figure 22) a different trend than the previous ones, relying on $\mathrm{CGI}^{62}$ to perform the in-game tasks that are expected of the game. The choice of a 3D aesthetic also aids the explanation as it is able to perform actions that would otherwise be hindered by the physical properties of real objects, as well as immersing players in the game's narrative.

By choosing a more loose format of 1 minute videos (average length), it is possible to constantly update the game with new information as it is released. However, the videos are not necessarily going to be displayed in a desirable order, because of YouTube's algorithms. Therefore, this choice devalues the explanation that it provides, as users are very unlikely to follow a streamlined order.

\footnotetext{
${ }^{62}$ Computer-generated imagery
} 


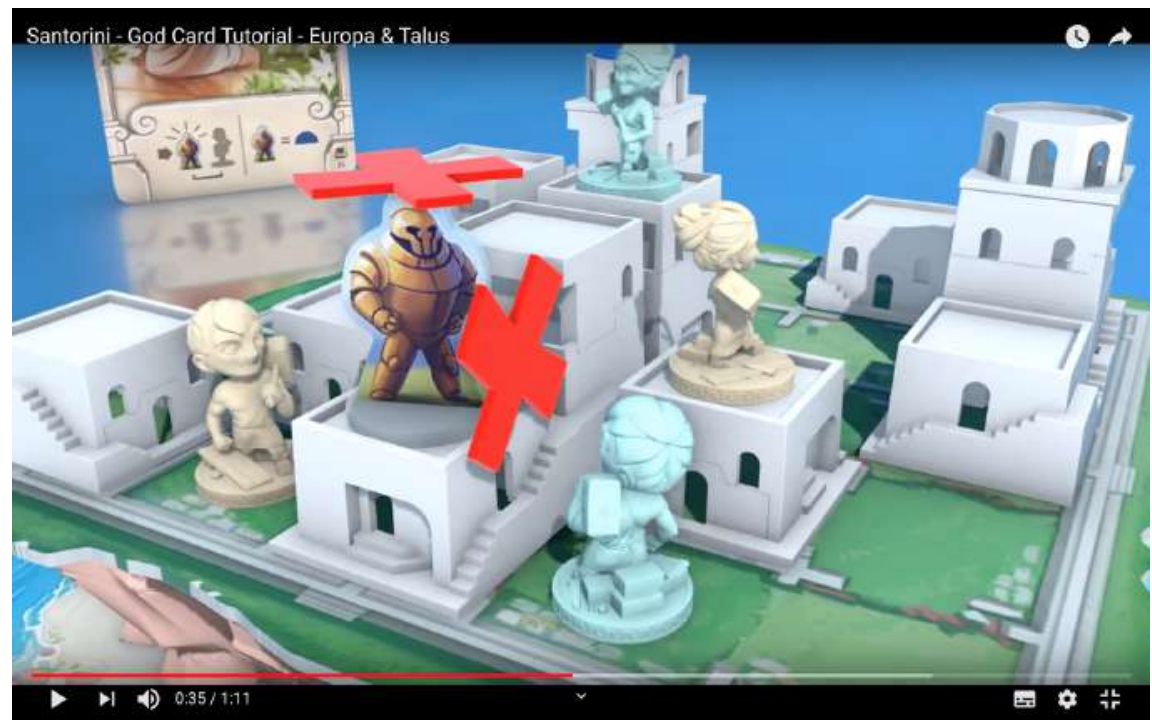

Figure 22 - Frame from one of Santorini's Video Tutorials.

The next step was to compare the information present in both rulebooks and video tutorials. Many of the video tutorials presented incomplete information, due to the choice of making them so short and concise. Furthermore, even relevant information about the specific topics they were about were not necessarily present, devaluing the experience of viewers. On the other hand, while the rulebooks presented all relevant information, they do not follow the previously established criteria, as show in table 7:

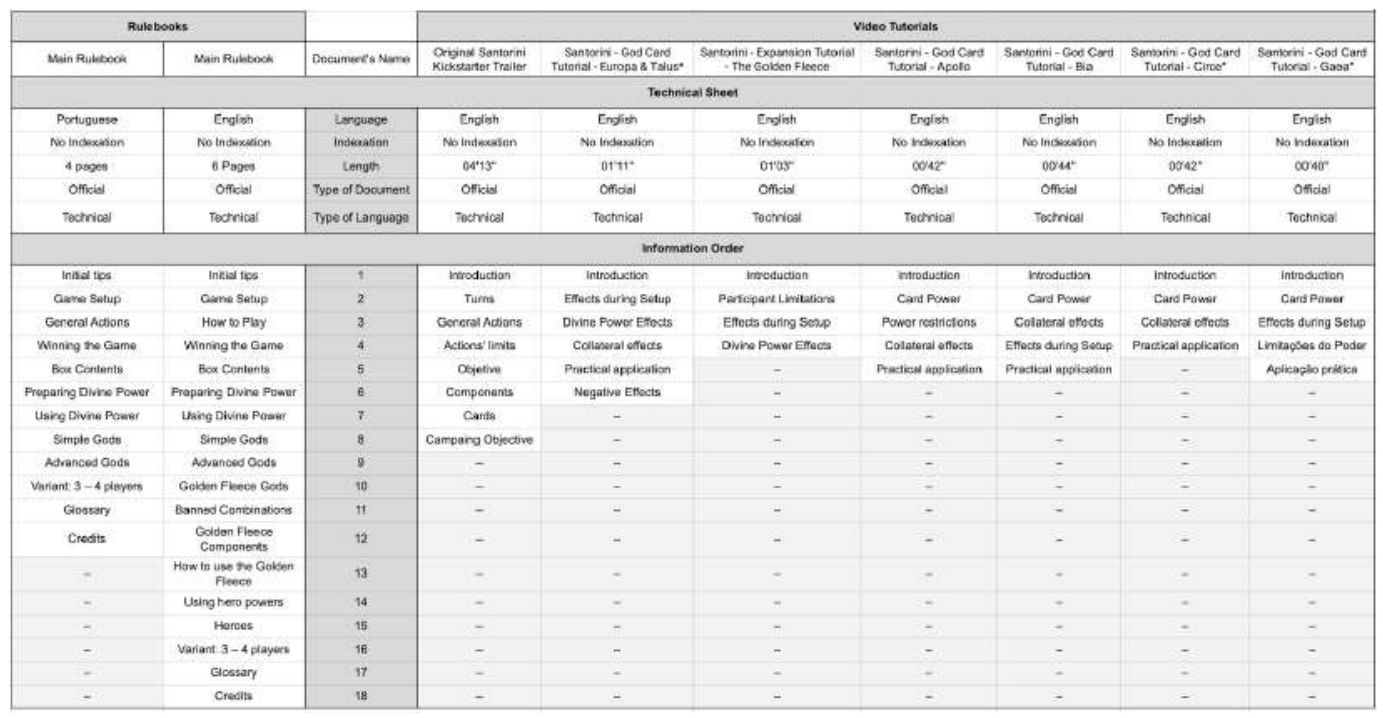

Table 7 - Comparison between Santorini's Rulebooks and Video Tutorials 


\section{5}

\section{Conclusions and Takeaways}

The only official regulation about manuals and rulebooks that was found in Brazil's CDC states that products should be accompanied by instructions of use and installation that are easy to understand, with illustrations. Due to the lack of further clarification, rulebook writers must instead rely on their own backlog of experience to write rulebooks, which seem to generate some kind of dissonance in those documents. Therefore, a bibliographical research was conducted in order to investigate other documents that could shed light onto this situation, serving as a theoretical framework for establishing new criteria of organization for rulebooks.

At the beginning of this research, based on Gagné's ideas that meaningful learning processes are achieved by contextualizing the learning objective, it was hypothesized that the first information that should be present in a rulebook is the game objective. The game objective is what gives meaning what gives meaning to the other rules: they teach the player how to win the game. However, Gagné focuses primarily on in-class scenarios, which are social situations. A rulebook, on the other hand, is a printed document, which often requires pre-textual elements (Jara, 2011) - such as covers, forewords, glossaries, etc. Even so, the initial assumption was somewhat correct, since the objective of the game is the first information of the actual text.

Other authors, such as Macklin (2015), and Tufte (1971) indicate that the order in which information should be presented in the rulebook should mirror the chronological order of events in the actual game. It becomes evident, then, that rulebook's text is a theoretical representation of the game, that alludes to its original characteristics. However, sometimes, the explanations presented must take a step further and depict actual game scenarios, situations which normally require the usage of images - whose primary function is to illustrate written texts that are harder to grasp (Unger, 2013; Macklin, 2015).

When comparing those findings to the actual experience of rulebooks, writers, they confirmed that the lack of references and guidelines create an 
environment where they must create their own rules and criterias for organization. However, even though there's no complete consensus amongst them about how the rules should be written or organized, their input corroborated the previously established hypothesis of how a rulebook should be organized. Their insight also took into consideration a new factor: that the rulebook must also contain the game's components, since consumers must be fully aware of what they are receiving when purchasing a game - much like any other product.

When evaluating rulebooks and video tutorials, by contrasting their content with the predictions of what should a rulebook contain, it became apparent that not a single one of the documents follow the criteria to a tee, which is not surprising, considering that game designers and rulebook writers must only rely on their practical experiences to do so. However, it is important to notice that official video tutorials, which were created in partnership with the companies that published the games, produced videos that were considerably better organized, containing fewer mistakes when explaining the rules. The non official ones, on the other hand had a much less technical approach, instead focusing on reviewing the game and providing entertainment value, through gameplay.

Lastly, this lack of a cohesive consensus on the organization of rulebooks and video tutorials further validates the importance of proposing new criteria of organization - that must be put to test. 


\section{6 Experimental Research: Testing Rulebooks}

In order to further validate the proposed criteria of organization - and since many respondents of the interview indicated how valuable it is to test rulebooks before their final version is complete - this research's next step was to test them in practice. In order to do so, an experimental research was proposed to evaluate the impact that rulebooks that followed the criteria from pages 93 and 94 would have on players' performances.

Therefore, the hypothesis being tested are: "Rulebooks whose information are properly organized will have positive impacts on players' learning curves, especially during first uses, reducing time spent reading them as well as the numbers of misunderstandings."; and "After reading adequate rulebooks, players will make fewer mistakes during game sessions."

The experiment consists of inviting volunteers to play two games: before playing one, they will interact with its original rulebook; before playing the other, they will interact with a revised version of the rulebook. Every group of players will play the same two games, but the rulebook that has been tampered with will vary, making it so that one half of the groups interact with the first and the other half with the second.

\section{1}

\section{Experiment's Description}

In order to conduct the experiment, two games were selected. Those games are: 1) No Thanks! - A set collection game in which players must score the lowest by collecting cards that form numerical sequences or, even better, not collecting 
cards at all. 2) SET - A set collection game in which players must try to form combinations of cards (SETs) faster than any other players.

They were selected because both are very similar in key aspects that render them more easily comparable amongst themselves:

both are well known games that have been released for sale more than 15 years ago; both have similar complexity ratings on BoardGameGeek's community poll: between 1 (Light) and 2 (Medium Light). Both are card games that encourage players to combine cards amongst themselves, evoking similar concepts and principles. Both are fast games, with average playing time of 30 minutes or under. Both games allow for groups between $3-7$ players to participate; both have very simple rulebooks, with only 2 pages each. Both have rulebooks that are not fully in compliance with the proposed criteria for the organization of information. Both have rulebooks that are in compliance with the proposed criteria for imagem usage, reducing the number of variables being evaluated. Neither of them have player aids, making it so that all players have to share one common rulebook. Neither of them require players to have previous knowledge about miscellaneous topics - aside from basic mathematical skills. Neither of them require dexterity to be played.

The preliminary hypothesis being tested in the experiment is that by altering the order in which the contents of rulebooks are displayed - in compliance with the proposed criteria - players who interact with the game for the first time will perform better, while also having a more positive outlook on reading rulebooks. To measure that hypothesis, the independent variable chosen was: The order in which information is displayed onto the chosen rulebooks. That variable's impact will be measured by the following dependent variables: the time elapsed reading the rulebook (minutes and seconds); the quantity of mistakes made by each player during a game session; the amount of times that the game was interrupted in order to check the rules; and the time elapsed during interruptions (minutes and seconds).

In order to avoid interference, four intervening variables were selected, and with the appropriate measures to avoid them: 
1. Player's familiarity with the game - they must have never played the game before participating in the experiment;

2. Player's age - they must eligible to play according to the game's age rating, which is compliant with the math skills required, according to the BNCC;

3. Player's schooling degree - they must all be within 2 years of acquiring their bachelor's degree, either before or after;

4. Amount of Players - all groups must be composed of $3-4$ players.

The experiment was applied following a strict script, considering that each group of players will play one match of each of the selected games. The first game will always be "No Thanks!, since it has a lower complexity score, and the second will be "SET", regardless of which game will contain the revised rulebook. Every odd group (1st, 3rd, 5th, ...) will interact with No Thanks!'s original rulebook and SET's revised rulebook, while even groups $(2 \mathrm{nd}, 4$ th,...$)$ will interact with No Thanks!'s revised rulebook and "SET"s original rulebook, guaranteeing that the sample sizes will remain exactly the same every time a even number of groups take part in the experiment ${ }^{63}$. Furthermore, each group will only receive one copy of the rulebooks - in order to mimic the real life scenario they would face if they were playing the game - and the lead researcher will not answer any questions regarding the games' rules of the experiment's application.

After playing each game, each player was asked to comment on what they thought about the rulebook, while also receiving a black and white photocopy of it, if they want to make any notes. The data analysis would have been conducted ${ }^{64}$ by comparing the results of the previously mentioned variables in three ways: Firstly, a quantitative comparison between each player's resulting dependent variables being collected, in order to rank the participants performance amongst their own group. Secondly, a quantitative comparison between each groups' performance - determined by both mean and median. Thirdly, a qualitative analysis about player's perceptions about the rulebooks.

\footnotetext{
${ }^{63}$ It is important to keep in mind, though, that only 2 groups participated, because of health and safety restrictions caused by Covid-19.

${ }^{64}$ Considering the sub-optimal sample size of participants, there was not enough data to wield proper analysis and results.
} 


\subsection{1}

\section{The Revised Rulebooks - No Thanks!}

No Thanks!'s revisions were as follows, depicted on figure 19:

1. The second paragraph from the section "Visão Geral" (Overview) became the third paragraph of the section "Como Jogar" (How to Play), since it dwells into game mechanics that had not yet been alluded to at the beginning of the rulebook.

2. The section "Pontuação" (Scoring) was moved to be after the section "Fim de Jogo" (End of the Game), since the scoring system is first mentioned in the end of the game section.

3. Considering that the experiment would not involve any tactical variants of the game, they were removed from the rulebook.
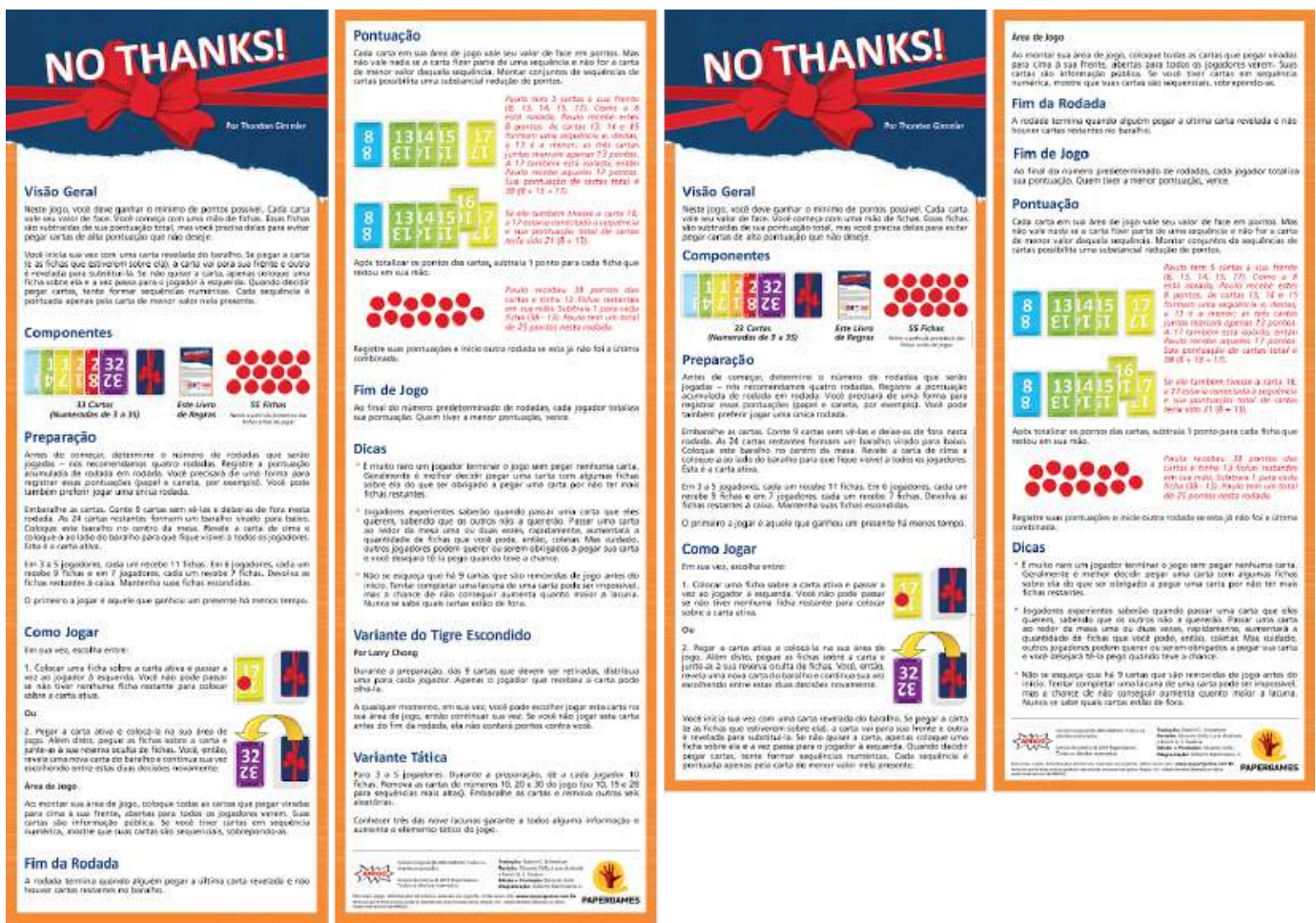

Figure 23 - On the left, the original version of No Thanks!'s rulebook; on the right, the revised version of No Thanks!'s rulebook, following this research's proposed criterion. 


\section{1 .2}

\section{The Revised Rulebooks - SET}

SET's revisions were as follows, depicted on figures 23 and 24:

1. The table that describes "Os exemplos a seguir são SETs" (The following examples are $\boldsymbol{S E T \boldsymbol { s } )}$ ) was moved to be immediately after the paragraph that explains what sets are.

2. The table that describes "Os exemplos a seguir $\boldsymbol{N} \tilde{A} \boldsymbol{O}$ são $\boldsymbol{S E T s " ~ ( T h e ~}$ following examples are NOT SETs), since it is directly tied to the previously mentioned table.

3. The text that says "Veja os exemplos ao lado" (Refer to the examples on the other side) was removed, since they no longer are where it indicates.

4. The sections "Verificação Rápida: É um SET?" (Fast checking: is it a SET?) and "Início Tranquilo" (Easy Start) were moved to the end, since players must understand how the game works before learning its variations.
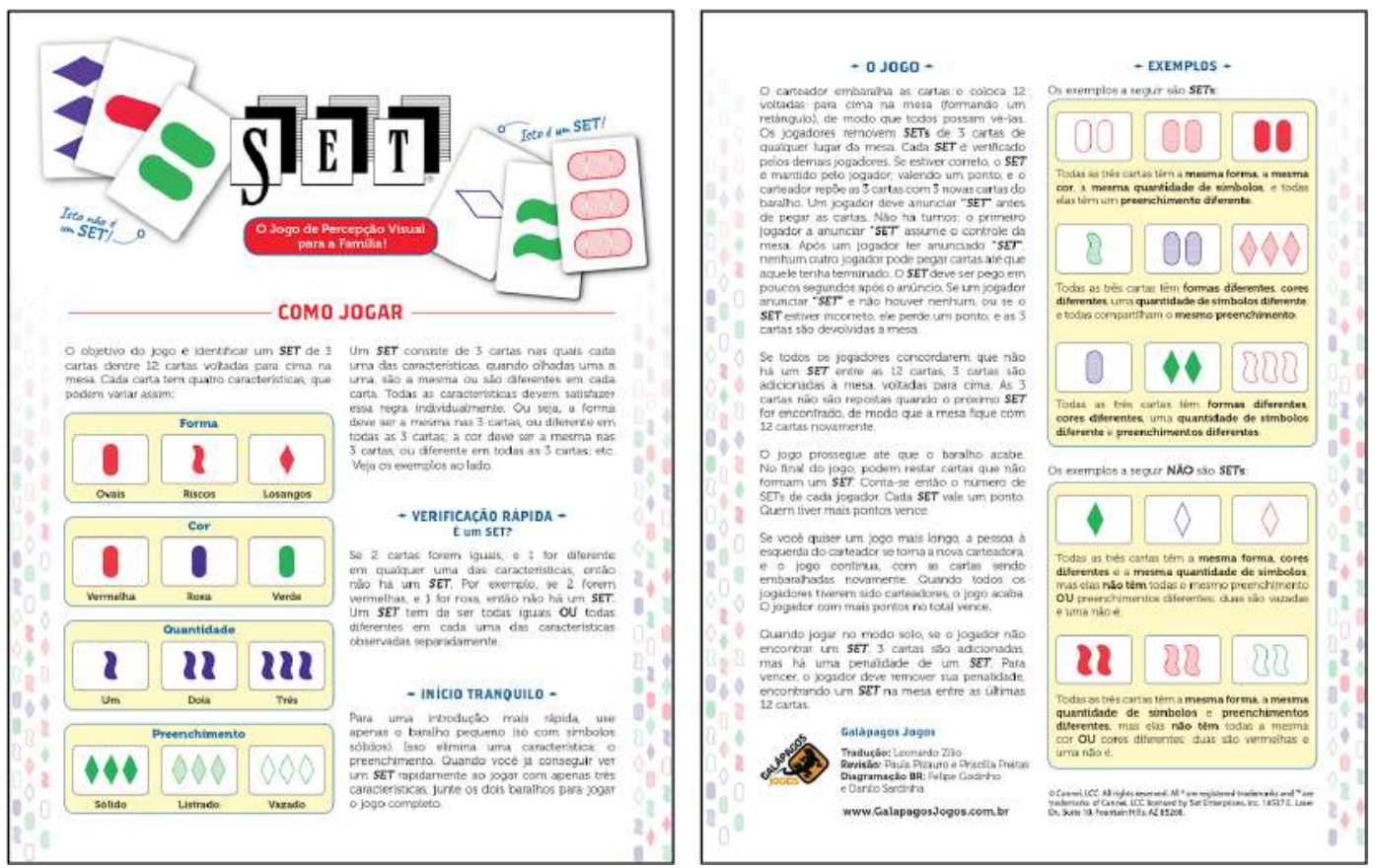

Figure 24 - Original version of SET's Rulebook. 

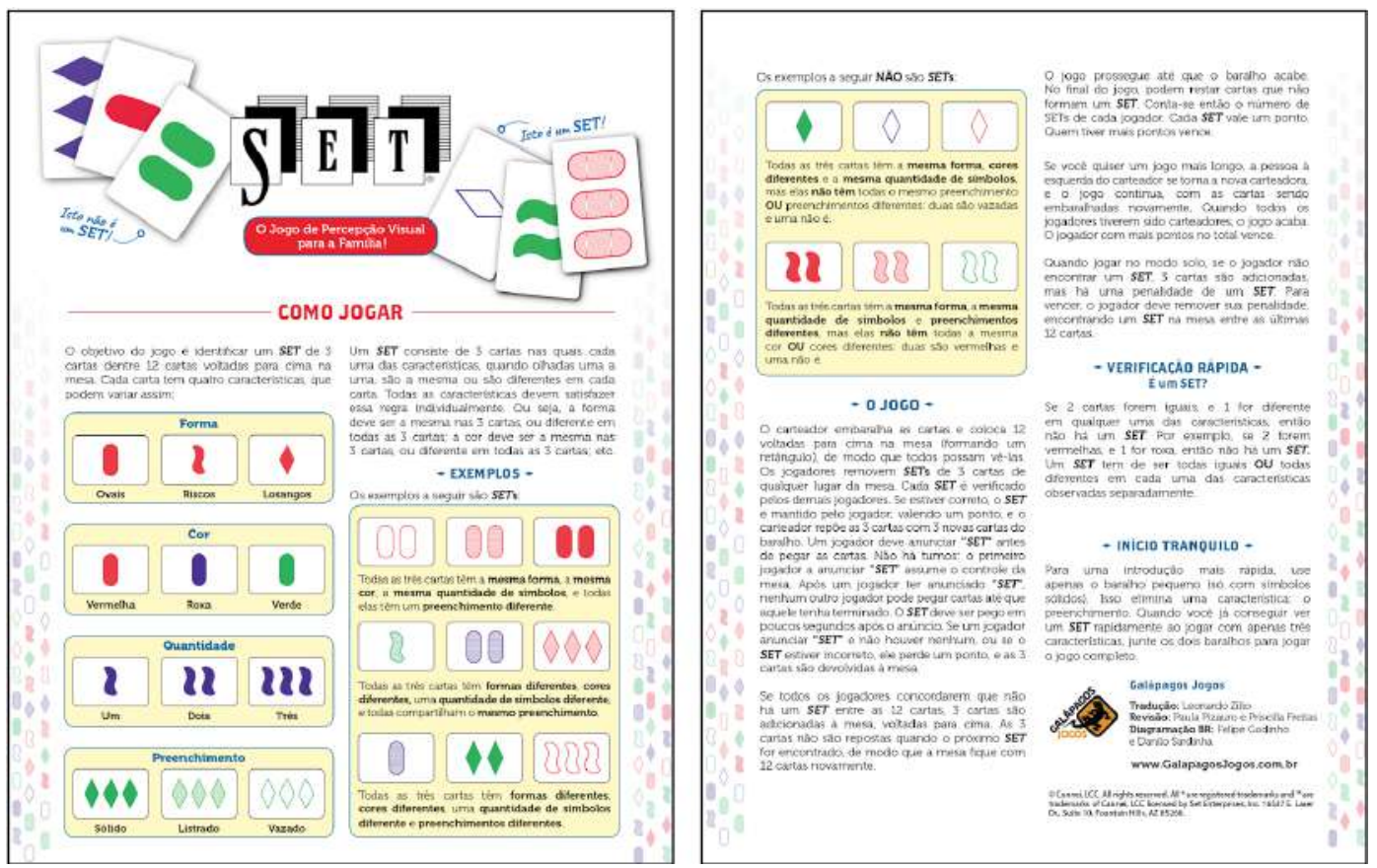

Figure 25 - Revised version of SET's Rulebook.

\section{2}

\section{Conducting the Experiment - Pretest}

In order to apply the experiment, a group of 7 game enthusiasts of the same age group - 25 to 29 years old (IBGE, 2019) - was invited to take part in the pretest. They were selected because they usually play games together, so that they could be more at ease with participating in the activity; because they were already in contact with each other; ${ }^{65}$ because they were unfamiliar with both games; and because they either had received their bachelor's degrees less than 2 years prior than the application of the experiment, or they were expected to receive their bachelor's degrees in fewer than two years.

Each participant received an informed consent form (Appendix III), stating their rights as volunteer participants. They were told that the experiment would be recorded via video and audio, and that they could interrupt their participation any time they wished, without suffering any repercussions, as well as the other

\footnotetext{
${ }^{65}$ Which was a determining factor for the pretest to be applied during the Covid-19 pandemic. Since they were already sharing the same space, they were not exposed to further risks of contamination by taking part in the experiment.
} 
relevant information for their participation. The forms were signed, and they were divided in two groups: one of three participants and the other of four, that interacted with each of the games according to the following text, illustrated on figure 26:

Group 1: 3 participants

1st Game: No, Thanks! (original rulebook)

2nd Game: SET (revised rulebook)

Group 2: 4 participants

1st Game: No, Thanks! (revised rulebook)

2nd Game: SET (original rulebook)

The results from each pretest were posteriorly analyzed, by watching the videos of the game sessions and calculating the previously mentioned dependent variables. Measures of time were calculated in minutes and seconds, while the quantity of mistakes were calculated in absolute numbers - both of which are displayed after each sessions' results.

\author{
GROUP 1
}

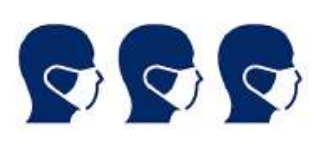

GROUP 2

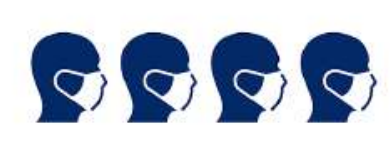

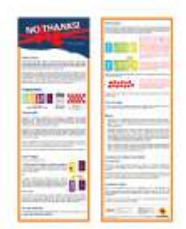

Original

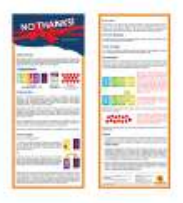

Revised

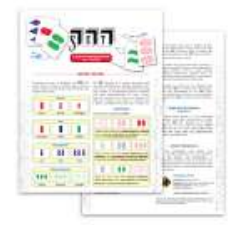

Revised

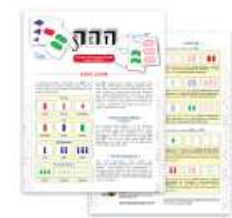

Original

Figure 26 - Display of Group 1's and Group 2's interaction with the original and revised rulebooks. 


\subsection{1}

\section{Conducting the Experiment (Pretest) - Group 1: No, Thanks!}

The first group was composed of 3 people: Player 1 (P1), Player 2 (P2), and Player 3 (P3). During the first game session, P1 took the liberty of reading the rulebook out loud. Whenever they paused the reading, generally at the end of each paragraph or period, the other participants signaled whether they understood or not what had been explained to them. If they had not, the group reread the paragraph until they were all satisfied with the explanation. Because of this, all three players seemed relaxed, without undergoing any kind of stress.

The second paragraph of the Overview seemed to be of particular concern to them, since they had many questions about it. Afterwards, the three of them indicated that many of the concepts brought up in it were difficult to understand, because the rulebooks casually mentioned them, as if they should already know what all of them meant, even if it was the first time. This seems to confirm the suspicions that this part of the text should not be where it is.

After reading the rulebook, P2 informed the other participants that they still had doubts, so they picked up the rulebook to quickly read it for the last time. After the game started, it all went down smoothly, with only one mistake happening: one player tried to draw a card outside of their turn, but immediately noticed their mistake and did not actually draw the card.

This sessions's data and results are displayed next:

- $\quad$ Reading time: $12^{\prime} 46^{\prime \prime}$

- Playing time: 07'48"

- Pauses: 1

- Total pause duration: 0'32"

- P1's Score/Mistakes: 15/0

- P2's Score/Mistakes: 14/0

- P3's Score/Mistakes: 77/1

- Collective mistakes: 0 


\section{2 .2}

\section{Conducting the Experiment (Pretest) - Group 1: SET}

When the game session started, P3 (who scored the worst on the first game) took the lead and started reading the new rulebook out loud. The group maintained the same dynamic of waiting for pauses in order to ask questions, which seemed to have worked for them.

In this game, the concept of "SET" is the main point of concern, since it is a Higher concept, harder to understand. However, this is precisely where the competitive aspect of the game stems from, since all players must try to form sets with the cards that are available on the board. When P3 arrived at the part of the rulebook that explained what a SET is, P2 informed that she hadn't completely understood what it meant, however, they noticed the table of examples, and referred to it in order to clarify the information. After they finished reading the table, they also noticed the images drawn at the top edges of the pages, which also describe combinations of cards that are SETs and others that are not.

They quickly grasped the rest of the rules and, following the suggestion ("Começo Rápido" - Quick Start) of the rulebook, played a mock-match to train their abilities in SET-making before starting an actual match.

Since SET is not a turn based game, and its main challenge involves the quick thinking of matching sets and the dexterity to quickly pick the cards, much more mistakes were made. However, those mistakes are woven into the game premise, therefore were separated between penalties (that are part of the game) and mistakes (that stem from misinterpreting the rulebook).

This sessions's data and results are displayed next:

- $\quad$ Reading Time: 11'50"

- Mock-playing time: 03'05"

- Playing time: 20'52"

- Pauses: 3

- Total pause time: 1'36" 
- $\quad$ P1's Score/Penalties: 10/6

- P1's Final Score/Mistakes: 4/2

- P2's Score/Penalties: $11 / 3$

- $\quad$ P2's Final Score/Mistakes: 8/0

- $\quad$ P3's Score/Penalties: 2/4

- $\quad$ P3's Final Score/Mistakes: -2/1

\section{2 .3}

\section{Conducting the Experiment (Pretest) - Group 2: No Thanks!}

The second group was composed of 4 participants: Player 4 (P4), Player 5 (P5), Player 6 (P6) and Player 7 (P7). In this group, P6 was the one who took the initiative to read the rulebook out loud, much like in the previous group. However, P4 interrupted them a considerable amount of times, to state that they had not understood what the paragraphs were saying. P7, later, pointed out that they started to lose track of the explanations as well, because of the interruptions, since they were not able to finish the sentences before being stopped.

In this version of the rulebook, the 2nd paragraph of the "overview" was moved, to allow for a better reading flow. However, even in the new location, it was the first time that the concept of a "sequence" was mentioned, which confused them - in particular P4 -, because they were unsure if 2 cards in sequence qualified as a sequence or if it had to be "like in Poker", with at least 5 cards. The general confusion, allied to the constant interrupting, seems to have made them gloss over one key piece principle of the game: if a player chooses to buy the open card, they may draw a new card and choose again if they want to pass (by using one of their chips) or keep it.

At the beginning of the match, due to this misunderstanding, all participants played considering that, no matter what option a player chooses, they pass their turn. It was only at $06^{\prime} 02^{\prime \prime}$ that P6 (the one who read the rules out loud) noticed that something seemed strange and went back into the rulebook to verify it. The 
players agreed that they should adopt the correct rule, and changed how they were playing from then on - but P4 seemed displeased about it. At the end of the match, P4 confessed being "discontent" because they had the highest amount of points, and forgot to check their score at the end of the game because they "had already lost either way"

This sessions's data and results are displayed next:

- Reading time: 09'50"

- Playing time (1st round): 11'06"

- $\quad$ Pauses: 1

- Total pause time: 1'35"

- P4's Score/Mistakes: 6766/1

- $\quad$ P5's Score/Mistakes: 36/0

- $\quad$ P6's Score/Mistakes: 14/1

- $\quad$ P7's Score/Mistakes: 36/0

- Collective mistakes: $13^{67}$

\subsection{4}

\section{Conducting the Experiment (Pretest) - Group 2: SET}

During this session, P4 (who had the worst score on the previous game) decided to read the rulebook themselves out loud. This time, no interruptions were made by the other participants.

Since they were reading SET's original rulebook, the SET examples were only at the end of the document. Therefore they had great difficulties comprehending how to form them. This situation seems to have caused a cascade effect, making it so they misinterpreted other relevant concepts. At the end of the reading process, $\mathrm{P} 4$ also skipped the tables with SET examples.

\footnotetext{
${ }^{66}$ Retrieved from footage.

${ }^{67}$ Whenever player's turns were skipped as a result of the collective misunderstanding of the rules, it was considered a collective mistake.
} 
The group played the game a total of 4 matches, all according to the "Quick Start" section of the rulebook. In which match, one of them was appointed as the dealer, who was responsible only for dealing and organizing the cards on the board. To their credit, the rulebook is ambiguous in regards to this specific rule, which explains why both groups had different interpretations. ${ }^{68}$

Considering that the group played a total of four rounds of the game, only the first one could be considered. As the process of learning games is incremental, players learn and adapt their strategies between rounds. Since Player 6 was the first round's dealer, they were not considered in the list of resulting data, having been skipped altogether. However, in order to properly document every player's performance, Table 8 details the data for each player, during each round.

- Reading time: 09'50"

- $\quad$ Playing time (1st round): 05'30"

- Pauses: 1

- Total pause time: 01'28"

- $\quad$ P4's Score/Penalties (1st round): 2/1

- $\quad$ P4's Final Score/Mistakes (1st round): 1/0

- $\quad$ P5's Score/Penalties (1st round): 5/0

- $\quad$ P5's Final Score/Mistakes (1st round): 5/0

- $\quad$ P7's Score/Penalties (1st round): $2 / 0$

- $\quad$ P7's Final Score/Mistakes (1st round): 4/0

\footnotetext{
${ }^{68}$ Particularly, I had never seen the dealer not playing, since my playing partners always tend to deal and play at the same time.
} 


\begin{tabular}{|c|c|c|c|c|c|}
\hline Round & Player & Score & Penalties & Final Score & Mistakes \\
\hline \multirow{4}{*}{$1 \mathrm{st}$} & P4 & 2 & 1 & 1 & 0 \\
\hline & P5 & 5 & 0 & 5 & 0 \\
\hline & P6 & - & - & - & - \\
\hline & $\mathrm{P} 7$ & 2 & 2 & 0 & 0 \\
\hline & & & & & \\
\hline \multirow{4}{*}{$2 n d$} & P4 & - & - & - & - \\
\hline & P5 & 3 & 1 & 2 & 0 \\
\hline & P6 & 2 & 2 & 0 & 0 \\
\hline & P7 & 2 & 1 & 1 & 0 \\
\hline & & & & & \\
\hline \multirow{4}{*}{$3 r d$} & P4 & 2 & 0 & 2 & 0 \\
\hline & P5 & 2 & 0 & 2 & 0 \\
\hline & P6 & 3 & 0 & 3 & 0 \\
\hline & P7 & - & - & - & - \\
\hline & & & & & \\
\hline \multirow{4}{*}{ 4th } & P4 & 0 & 0 & 0 & 0 \\
\hline & P5 & - & - & - & - \\
\hline & P6 & 4 & 0 & 4 & 0 \\
\hline & P7 & 3 & 0 & 3 & 0 \\
\hline
\end{tabular}

Table 8 - Data resulting from Group 2's performance while playing SET. Green cells highlight the best performance from each round, while red cells highlight the lowest, disconsidering ties.

\section{3}

\section{Experiment's Analysis (Pretest)}

During the pretest, many points of concern were brought to attention. First of all, because of the Covid-19 pandemic, it was not possible to conduct further experiments with corrections based on the findings.

Moreover, the small sample space doesn't seem to provide any type of relevant statistical results, causing much of the conclusion to result in hints based on a qualitative perspective on those limited samples. Beyond the scope of simply 
re-organizing the rule's orders, the experiment has shed light on other topics that are worth mentioning, since they relate to the literature review that was explored in Chapters 3, 4 and 5.

Firstly, some concepts and principles required further clarification, especially ones that have different meanings depending on the context. One such example, which luckily did not really negatively impact players' performance was the instruction to "for a rectangle using 12 cards". One of the groups outlined $5 \times 3$ cards, while the other made a filled rectangle of $4 \times 3$ cards, as shown in figure 27.

Secondly, players' values, previous experiences and attitudes will impact their performance on the game, as well as their peers'. Group 2 had a rougher time understanding both game's rules, even when exposed to the revised rulebook, which seems to have been caused by one of the players, who both interrupted their peers and skipped entire sections of the rulebook when it was their time to read.

In order to measure that disruption, the groups' performances while playing SET were analyzed, since Group 1's mock-round and Group 2's first round followed the same patterns and rules. While the second group had a shorter reading time, this probably ${ }^{69}$ was due to $\mathrm{P} 4$ skipping the last part of the rulebook. This fact seems to have negatively impacted Group 2, since they performed worst in 5 out of the 8 categories which are detailed in table 9.

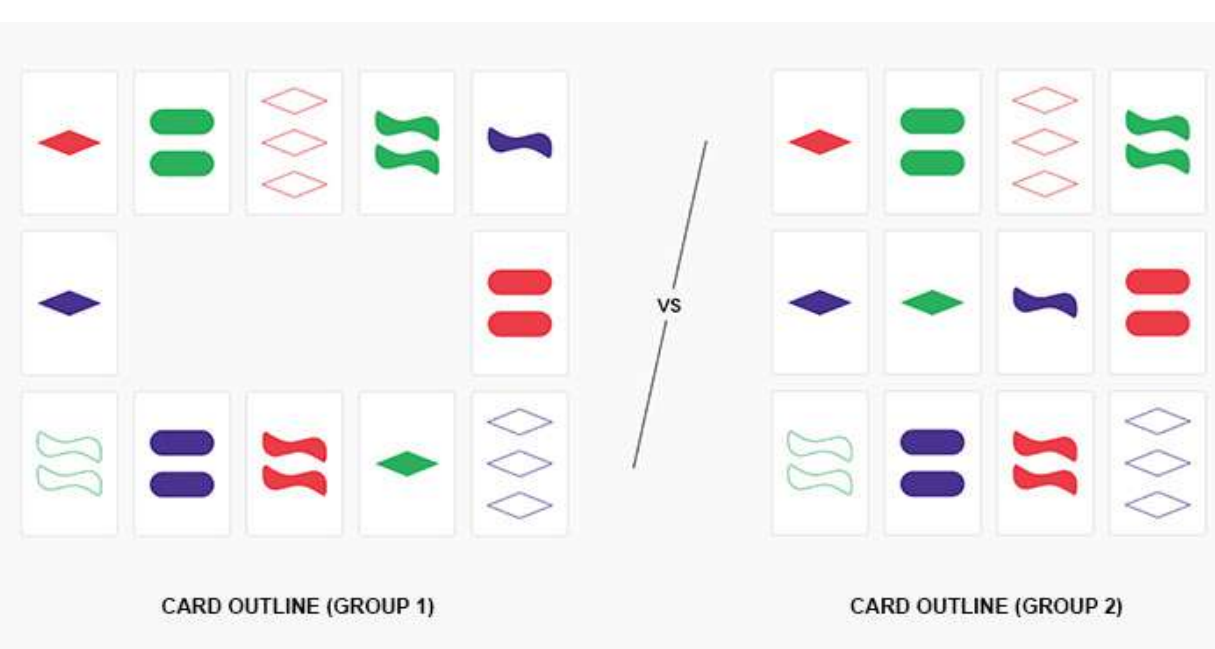

Figure 27 - Comparison between how players arranged their cards in each group.

\footnotetext{
${ }^{69}$ Since it is not possible to predict how long they would take to read the last part of the rulebook, this observation calls for speculation.
} 


\begin{tabular}{|c|c|c|c|c|c|c|c|c|}
\hline \multirow{2}{*}{ SET } & \multicolumn{3}{|c|}{ Scoring } & \multicolumn{3}{c|}{ Mistakes } & \multicolumn{2}{c|}{ Duration } \\
\hline Group & $\begin{array}{c}\text { Highest } \\
\text { Final Score }\end{array}$ & $\begin{array}{c}\text { Lowest Final } \\
\text { Score }\end{array}$ & $\begin{array}{c}\text { Average } \\
\text { Final Score }\end{array}$ & $\begin{array}{c}\text { Highest } \\
\text { Mistakes }\end{array}$ & $\begin{array}{c}\text { Lowest } \\
\text { Mistakes }\end{array}$ & $\begin{array}{c}\text { Average } \\
\text { Mistakes }\end{array}$ & $\begin{array}{c}\text { Reading } \\
\text { Time }\end{array}$ & $\begin{array}{c}\text { Playing } \\
\text { Time }\end{array}$ \\
\hline 1 & 4 & 1 & 2,33 & 0 & 0 & 0 & $11^{\prime} 50^{\prime \prime}$ & $3^{\prime} 05^{\prime \prime}$ \\
\hline 2 & 5 & 0 & 2 & 2 & 0 & 1 & $09^{\prime} 50^{\prime \prime}$ & $5^{\prime} 30^{\prime \prime}$ \\
\hline
\end{tabular}

Table 9 - Comparison between Group 1 and Group 2's performances. Green cells represent the better results, while red cells represent worse results.

Furthermore, in both groups, the players who had the lowest performance in each while playing No Thanks! (P3 and P4) were not the ones reading its rulebook for the group. However, when interacting with SET for the first time, they both took on the role of rulebook reader. While this seems to indicate that their apparent apprehension was due to their poor performance, the sample space is far too small to suggest a real causal relation between those two facts.

Moreover, when playing several matches of the same game, players started to make more points and fewer mistakes, while also taking less time to finish the matches - which supports Mayer's model of incremental learning through multimedia documents. Naturally, since one player was absent in each round, the group's average might be prone to suffering some inconsistencies, but the last two rounds clearly represent an overall better performance, as shown in table 10.

\begin{tabular}{|c|c|c|c|c|c|c|c|}
\cline { 2 - 8 } SET & \multicolumn{3}{|c|}{ Scoring } & \multicolumn{3}{c|}{ Mistakes } & Duration \\
\hline Round & $\begin{array}{c}\text { Highest } \\
\text { Final Score }\end{array}$ & $\begin{array}{c}\text { Lowest } \\
\text { Final Score }\end{array}$ & $\begin{array}{c}\text { Average } \\
\text { Final Score }\end{array}$ & $\begin{array}{c}\text { Highest } \\
\text { Mistakes }\end{array}$ & $\begin{array}{c}\text { Lowest } \\
\text { Mistakes }\end{array}$ & $\begin{array}{c}\text { Average } \\
\text { Mistakes }\end{array}$ & $\begin{array}{c}\text { Elapsed } \\
\text { Time }\end{array}$ \\
\hline 1st & 5 & 0 & 2 & 2 & 0 & 1 & $5^{\prime} 30^{\prime \prime}$ \\
\hline 2nd & 2 & 0 & 1 & 2 & 1 & 1,33 & $4^{\prime} 30^{\prime \prime}$ \\
\hline 3rd & 3 & 2 & 2,33 & 0 & 0 & 0 & $2^{\prime} 30^{\prime \prime}$ \\
\hline 4th & 4 & 0 & 2,33 & 0 & 0 & 0 & $3^{\prime} 15^{\prime \prime}$ \\
\hline
\end{tabular}

Table 10 - Group 2's performance during their 4 rounds of SET. Red cells represent the worst performance in regards to that metric; dark green cells represent the best performance; and light green cells represent intermediate performances. 
Lastly, by allowing players to interpret the rulebooks freely, when they contained alternative versions of the game, without clear directions on which type of game they would play, the groups reached different conclusions, which rendered their results even harder to properly compare. Upon reflection, by removing the tactical variant from No Thanks!'s revised rulebook, the experiment might have generated a null result, since the players from that group interacted with a rulebook that had 2 independent variables that were tampered with, making it impossible to determine which one was responsible for which outcome.

In order to generate more relevant data, No Thanks!'s rulebook must be revised, reintegrating the tactical variants. It would also be positive to give players more clear instructions that they should play a regular match of each game, to mitigate possible misunderstandings in the future.

Lastly, it is important to notice that there are limits to what insights the literature review alone can provide. Perhaps, other minor changes in the order of sentences, periods, or paragraphs would provide much better results, but this investigation can only be made in the future, whenever it does not risk the health and safety of all participants who are willing to volunteer themselves. 


\section{Conclusion and Results}

Even though much has already been discussed about tabletop games as learning tools, the process of learning tabletop games themselves has received very little attention in the academic field. This situation creates a scarcity of academic references about the subject - however, on the other hand, it allowed for a pioneer study about the cognitive processes behind learning how to play tabletop games, focusing on rulebooks and their informational design.

This research's preliminary hypotheses predicted that a well-thought and properly organized rulebook would provide much more meaningful learning experiences for players - which would, in turn, allow them to perform better when playing games for the first time. However, there was no available frame of reference to determine what a "properly organized rulebook" is.

In order to investigate that, it was necessary to first comprehend why and how players learn to play games. So, considering that, by nature, design is a multidisciplinary field of study, an extensive bibliographical research was conducted, investigating references from the fields of social studies, psychology, neurolinguistics, education, and human factors \& ergonomics.

By evaluating the theoretical framework provided by those fields of study, it was possible to translate their concepts and ideas to the context of tabletop games, their rulebooks, and the process of learning how to play them.

Upon concluding this research, there is no doubt that there are many aspects of the informational project of rulebooks that greatly benefit from the vast knowledge of the fields of Human Factors and Ergonomics, Linguistics, Education and Psychology. This dissertation represents a small first step towards that scenario - which, hopefully, might trigger a ripple effect in the academic field, that - sadly - up to this moment has paid close to no attention to Tabletop Game's rulebooks. 
While the vast benefits of playing games have been more than proven by now, as well as the extreme effectiveness of games as learning tools; there's yet much to discuss the process of learning the games themselves. Rulebooks are considered by many as boring texts that take away the fun from the games. That reality is no surprise, considering that most - if not practically all - rulebook writers only write them out of necessity - because the still isn't space in the market for professionals specialized in creating good, organized and player-oriented rulebooks.

This research was greatly done to shed light onto this tragic situation and, perhaps, bring attention to the positive aspects of investing in rulebooks, so that they might reflect the good qualities of the games they were designed for. If so, they could bring significant benefit for players of all ages, by contributing to the preservation of the magic circle that circumscribes the moments of playing

The literature review presented in chapters 2 through 5 detail the many aspects that should be taken into consideration whenever writing a good rulebook, thus validating this Dissertation's second hypothesis ${ }^{70}$, while also paving the way to the next methodological step of the research: the Inquiry.

During the interviews that were conducted with game designers and rulebook writers, it became apparent that this dissertation's first hypothesis ${ }^{71}$ is also valid. Their empirical experience shows that, by defining clear criteria and producing a script to guide the process of writing rulebooks, they improved their craft, pioneering many of the positive criteria that were then proposed here.

Unfortunately, during the second year of this research, the global health crisis caused by the Covid-19 outbreak did not allow for the experimental methodology to be thoroughly applied. Even if the pretests hinted at positive results that initially seem to corroborate both the third ${ }^{72}$ and fourth hypothesis ${ }^{73}$, it

\footnotetext{
${ }^{70}$ The first information in rulebooks should be the game's objective, in order to help players contextualize the significance of what is being learned.

${ }^{71}$ Defining clear and replicable criteria of organization for tabletop games' rulebooks will help producing rulebooks that are easier to read and comprehend.

${ }^{72}$ Rulebooks whose information are properly organized will have positive impacts on players' performances, especially during first uses, reducing time spent reading them as well as the numbers of misunderstandings.

${ }^{73}$ After reading adequate rulebooks, players will make fewer mistakes during game sessions. For this purpose, "mistakes" are going to be considered: actions that break the game's rules; actions
} 
would not be intellectually honest to say that they were truly proven right in practice.

In spite of that, the overwhelming theoretical evidence, together with the hints that resulted from the application of the pretest are enough to conclude this dissertation on a positive note, by proposing:

Firstly, an updated version of Mayer's model of cognitive processing in multimedia documents, specific for the context of tabletop games and their rulebooks, adapted to cover video-tutorials as well, as seen on figure 28 . The author addresses the cognitive processes involved in multimedia learning,by demonstrating how data and information are captured by the senses of sight and hearing; processes by the working memory; and then integrated, by being contrasted with the knowledge stored in long-term memory. This model fits perfectly into the process of learning how to play tabletop games - either by reading rulebooks or watching video tutorials, allowing for a relevant insight on the cognitive functions that are behind it.

Secondly, an improved version for the revised rulebooks used on the experiment was proposed (figures 29 and 30), incorporating the new findings from the pretest into their layout and informational design. This improvement further validates the importance of testing rulebooks with players, since there will always be a limit to what a theoretical framework can contribute to practical activities. This is a practice that should be encouraged in the market of game design, and which was highly recommended by the interview participants.

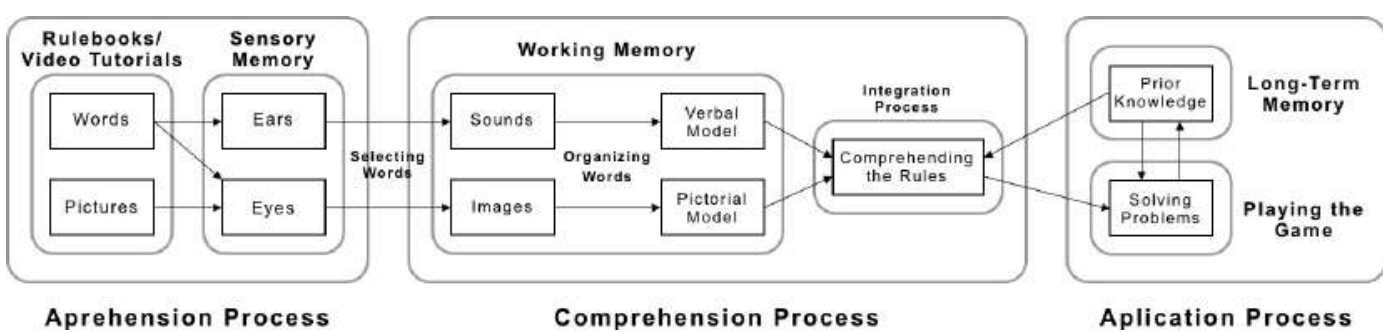

Figure 28 - Updated version of the proposed cognitive processing model of multimedia texts, in order to include video tutorials as well.

that, while not breaking any rules, are not allowed to be made at that point; actions that are allowed, but do not deliver the results that the player making them expected. 


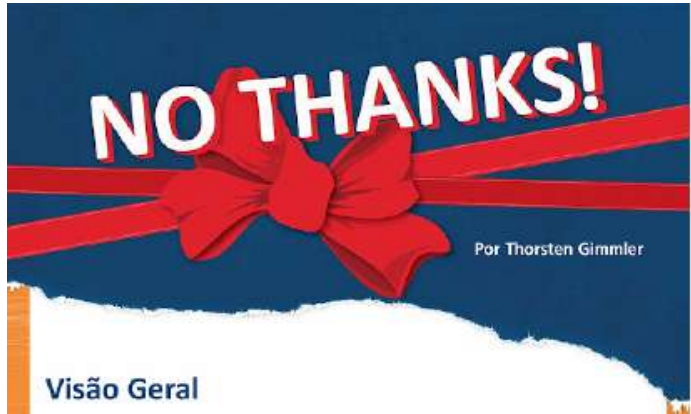

Neste jogo, você deve ganhar o mínimo de pontos possivel. Cada carta vale seu valor de face. Você começa com uma máo de fichas. Essas fichas

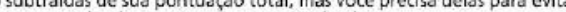
pegar cartas de a

\section{Componentes}
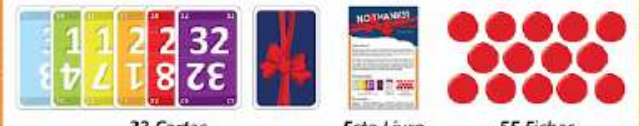

33 Cartas
(Numeradas de 3 a 35 )

Este Livro

55 Fichas

\section{Preparação}

Antes de começar, determine o número de rodadas que serāo jogadas - nos recomendamos quatro todadas. Registre a pontuaça registrar essas pontuacōes (papel e caneta por exemplo) Vocé pad tambèm preferir jogar uma única rodada.

Embaralhe as cartas. Conte 9 cartas sem vê-las e deixe-as de fora nesta rodada. As 24 cartas restantes formam um baralho virado para baixo. coloque este baralho no centro da mesa. Revele a carta de cima Esta e a carta ativa.

Em 3 a 5 jogadores, cada um recebe 11 fichas. Em 6 jogadores, cada um recebe 9 tichas e em 7 jogadores, cada um recebe 7 fichas. Devolva

O primeiro a jogar é aquele que ganhou um presente hả menos tempo.

\section{Como Jogar}

Em sua vez, escolha entre:

1. Colocar uma ficha sobre a carta ativa e passar a vez ao jogador à esquerda. Você năo pode passar se nà tiver nenhuma ficha restante para colocar

ou

2 Pegar a carta ativa e coloć́-la na sua śrea de jogo. Alèm cisto, pegue as fichas sobre a junte-as à sua reserva oculta de fichas. Você, então, revela uma nova carta do baralho e continua suavez escolhendo entre estas duas decisôes novamente.

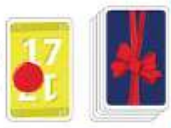

Você inicia sua vez com uma carta revelada do baralho. Se pegar a cart (e as fichas que estiverem sobre ela), a carta vai para sua frente e outro ficha sobre ela $\mathrm{e}$ a vez passa para o jogador à esquerda, Quando decidi pegar cartas, tente formar sequências numéricas. Cada sequéncia é pontuada apenas pela carta de menor valor nela presente.

\section{Área de Jogo}

Ao montar sua área de jogo, coloque todas as cartas que pegar viradas para cima à sua frente, abertas para todos os jogadores verem. Suas numérica, mostre que suas cartas sấo sequenciais, sobrepondo-as.

\section{Fim da Rodada}

A rodada termina quando alguèm pegar a última carta revelada e não houver cartas restantes no baralho.

\section{Pontuação}

Cada carta em sua área de jogo vale seu valor de face em pontos. Mas näo vale nada se a carta fizer parte de uma sequência e nāo for a carta cartas possibilita uma substancial reduçă de pontos: Paulo tem 5 cartas à sua frente $(8,13,14,15,17)$. Como a 8

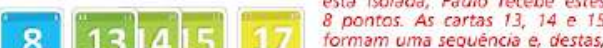
8 ET TT

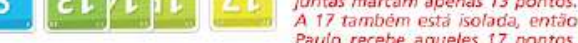
Paulo recebe aqueles 17 pontos. Sua pontuasăo de cartás total é
$38(8+13+17)$

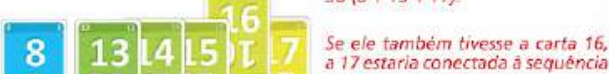
8 ET 8 (T)

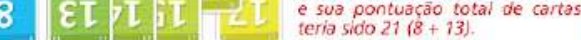
Apos totalizar os pontos das cartas, subtraia 1 ponto para cada ficha que restou em sua mão.

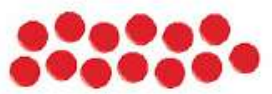

Paulo recebeu 38 pontos das em sua mäo subtraia 1 para cada ficha (38-13). Paulo tem um total de 25 pontos nesta rodada.

Registre suas pontuaçỏes e inicie outra rodada se esta já não foi a última combinada.

\section{Fim de Jogo}

Ao final do número predeterminado de rodadas, cada jogador totaliza sua pontuaçāo. Quem tiver a menor pontuaçāo, vence.

\section{Dicas}

* É muito raro um jogador terminar o jogo sem pegar nenhuma carta. Geralmente e mehor decidir pegar uma carta com algumas fichas fiche ela do que ser obrigado a pegar uma carta por nao ter mais

* Jogadores experientes saberão quando passar uma carta que eles querem, sabendo que os outros năo a quererào. Passar uma carta ao redor da mesa uma ou duas vezes, rapidamente, aumentara a quartidade de fichas que vocé pode, entáo, coletar. Mas cuidado, evorê desejará tếla pego quando teve a chance

Não se esqueça que há 9 cartas que são removidas de jogo antes do início. Tentar completar uma lacuna de uma carta pode ser impossivel, mas a chance de não conseguir aumenta quanto maior a lacuna.

\section{Variante do Tigre Escondido} Por Larry Chong

Durante a preparação, das 9 cartas que devem ser retiradas, distribua uma para cada jogador. Apenas o jogador que recebeu a carta pode

A qualquer momento, em sua vez, vocé pode escolher jogar esta carta na sua área de jogo, então continuar sua vez. Se vocé náo jogar
antes do fim da rodada, ela năo contara pontos contra vocé.

\section{Variante Tática}

Para 3 a 5 jogadores. Durante a preparação, dé a cada jogador 10 fichas. Remova as cartas de numeros 10, 20 e $30 \mathrm{do}$ jogo tou 10, 19 e 28 para sequ
aleatorias.

Conhecer três das nove lacunas garante a todos alguma informação e aumenta o elemento tático do jogo.

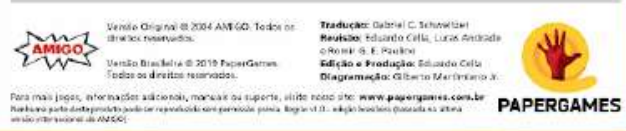

Figure 29 - Updated version No Thanks!'s revised rulebook. 

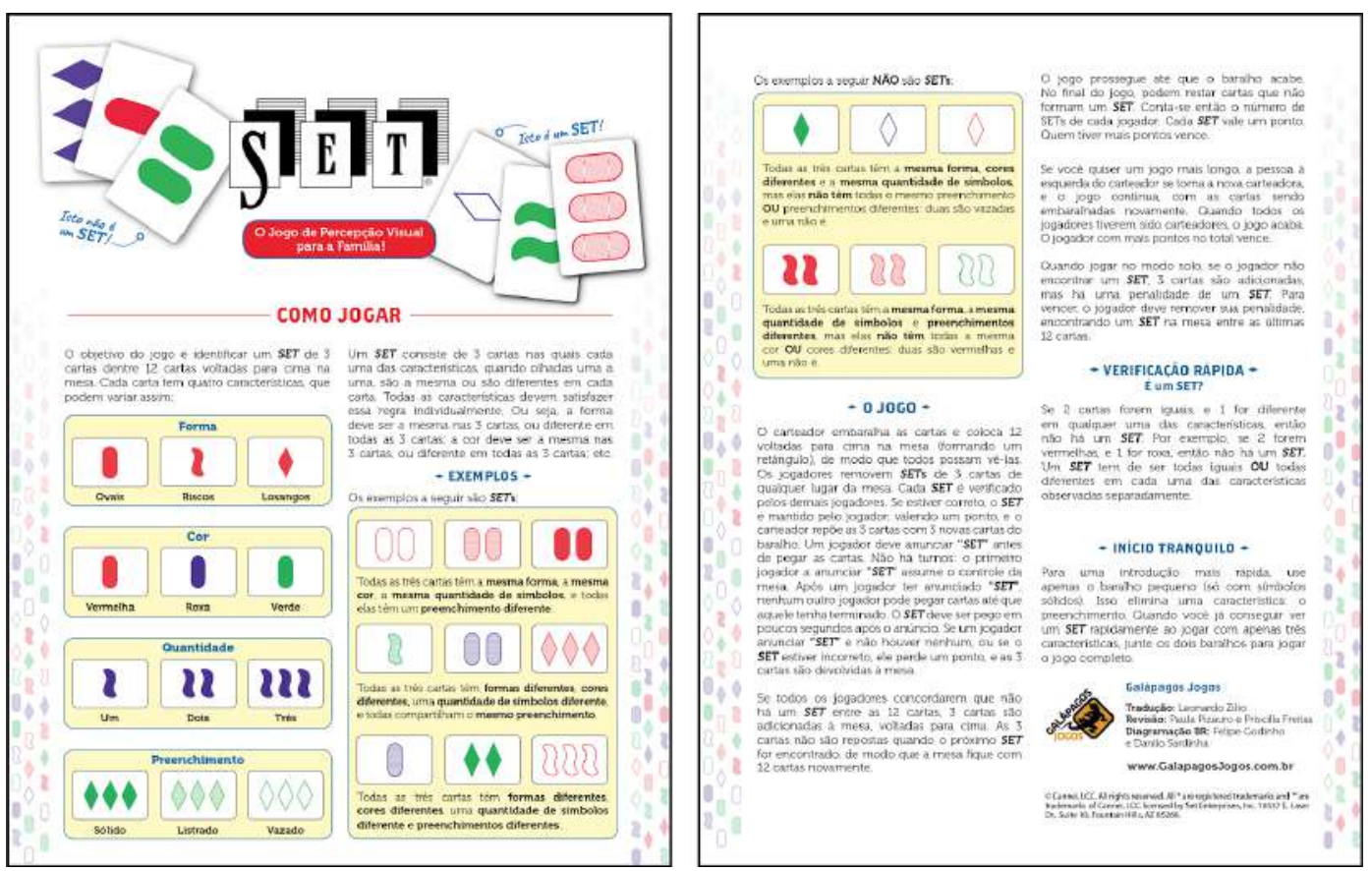

Figure 30 - Updated version of SET's rulebook.

On the third place, a set of criteria to guide the organization of any given rulebook's content - with a small caveat that the experimental part of the research should still be conducted, when global health and safety conditions are not at risk.

1) Rulebooks must contain a contextual introduction that explains the in-universe situations that motivate players to play the game.

2) If at all necessary, rulebooks must contain a glossary of concepts, which should define the meaning of key concepts of the game. The glossary may be located either at the beginning or at the end of the rulebook - but, if located at the end, players should be made aware of that beforehand, so they may refer to the glossary, if needed.

3) Rulebooks must contain a list of components. It follows the exact same specifications as the glossary of concepts. 
4) The first information of the actual text of the rulebook must be the game objective, which shouldn't simply be "to win the game", but explain how even if briefly - the game is won.

5) The rest of the rules should follow the natural course of actions that take place before, during and after the game. Generally, the first one is the game setup - which describes the state of the game at the beginning of the match - and the last one is the end of the game - which describes the end-game trigger -, followed, if necessary, by scoring rules.

6) Whenever relevant, pictures, illustrations, graphs and diagrams should be used in order to further clarify the meaning of the rules. Those imagetic assets should be displayed next to the text they refer to.

7) Generally, the rules that require the aid of images are practical examples of plays, game-scenarios, and situations.

8) Other parts of the rulebook might require the usage of images, so it is important to test the rulebooks with players from the actual target audience in order to identify other points of contingency.

Those findings can be of great use to the field of design and ergonomics, since they open a new pathway to studying player-centered design and can be of much help to game designers and rulebook writers, especially ones that still do not have a vast personal experience with designing games and rulebooks. In turn, they could also represent a new paradigm for designing boardgame rulebooks by applying the principles and methodologies of user-centered design and human-centered design to this activity.

By considering players' context and mindset while playing games - which were often described by Huizinga (1949) - it becomes even more apparent that the rulebooks are an important document that should be further developed, in order to protect the magic of playing games. However, those documents face 
many limitations due to the current configuration of their interfaces, which have been practically unchanged in the last century. This phenomena has allowed for complementary niches of learning situations to arise, such as the video tutorials analyzed on chapter 5, and thematic bars and events, where players learn the games from trained professionals, instead of relying on rulebooks.

\section{1}

\section{Caveats and Next Steps}

Part of this research's hypotheses depended on a practical test, which had to be conducted in person, with volunteer participants. Due to the Covid-19 pandemic, this step of the research could not be completed, instead having to rely on the partial results of pretests. However, since Brazil is still in its first stages of the national vaccination plan, it was considered to be best to finish the research in this current state, since the theoretical frame of analysis that it presented makes a strong case for the hypothesis being tested.

On the other hand, it would be of much interest to conclude the experiment whenever the national health and safety conditions allow for it. Therefore, it is my intention to conduct this part of the research in the future, applying the new inputs that were gathered during the pretests. The full experiment's results should be published in the future, in order to further validate or revise this research's conclusion and takeaways.

It could also be interesting to invite game designers and rulebook writers to revise their own rulebooks based on this research's proposed criteria, allowing for more games and rulebooks to be tested. The very process of applying the criteria to a variety of documents could also disclose other points of attention that have not surfaced so far.

While this research scratched the surface of the process of learning games through rulebooks, there's still much to be discussed. Even though they are 
indispensable documents that guarantee consumers' rights to have access to relevant information about the games they purchase and play; the printed media is becoming fastly obsolete.

The rise of video tutorials, apps, and online versions of games that were originally designed to be released as tabletop games, represent a paradigm shift in the market of tabletop games - which is to be expected, since games are a product of the sociocultural means where they are inserted. Online platforms, like Tabletopia and Tabletop Simulator, have become extremely prominent in the past year, especially considering that, due to the Covid-19 pandemic, many people cannot gather with their social groups to play tabletop games. In the past twelve months, Tabletop Simulator has received more positive reviews on Steam than it had previously since its release, in june, 2015.

For this reason, it would be recommended that the process of learning those games on virtual platforms should also be studied, in order to identify the similarities and distinctions between them and their non-digital counterparts. 


\section{Bibliography}

ANVISA (Brasil). Resolução - RDC No 360. 2003. Available at: $<$ http://bvsms. saude.gov.br/bvs/saudelegis/anvisa/2003/rdc0360 23 12 2003.html> Access on: 29 jan. 2021.

ANZANELLO, M. J.; FOGLIATTO, F. S. Curvas de aprendizado: estado da arte e perspectivas de pesquisa. Gest. Prod., São Carlos, v. 14, n. 1, p. 109-123, jan.-abr. 2007.

BAKOS, M. M. Fatos e Mitos do Antigo Egito. 3rd Edition, Reprinted. Porto Alegre: ediPUCRS, 2014.

BARTH, F. O Guru, o Iniciador e Outras Variações Antropológicas. Rio de Janeiro: Contra Capa Livraria, 2000.

BONSIEPE, G. Design, Cultura e Sociedade. 1st Reprinting. São Paulo: Blucher, 2013.

BRASIL. Base Nacional Comum Curricular. Available at: $<$ http://basenacional comum.mec.gov.br/images/BNCC_EI_EF_110518_versaofinal_site.pdf $>$ Access on: 29 jan. 2021.

Code of Consumer Defense and Protection. Rio de janeiro, 2014. Available at: <http://www.procon.rj.gov.br/procon/assets/arquivos/arquivos/CDC Novembro 2014 Ingles.pdf $>$ Acess on: 18 mar. 2021.

Código de Defesa do Consumidor e Normas Correlatas. - 2. ed. Brasília: Senado Federal, Coordenação de Edições Técnicas, 2017. Available at: $<$ https://www2.senado.leg.br/bdsf/bitstream/handle/id/533814/cdc_e_normas_corr elatas_2ed.pdf> Access on: 29 jan. 2021.

. Edital de Convocação 01/2018 - CGPLI Edital de Convocação para o Processo de Inscrição e Avaliação de Obras Didáticas e Literárias para o Programa Nacional do Livro e do Material Didático PNLD 2020. 2018. Available at: <https://www.fnde.gov.br/programas/programas-do-livro/consultas/editais-pro gramas-livro/item/11555-edital-pnld-2020> Access on: 29 jan. 2021.

BROADBENT, D. E. Language and Ergonomics. Applied Ergonomics, England, v. 8.1, p. 15-18, march 1977.

CHAPANIS, A. Words Words Words. $8^{\circ}$ Encontro Anual da Human Factors Society. V. 7, n. 1, p. 1-17, Maryland, United States of America, 1965.

CoEU; EP. Directiva 2009/48/CE do Parlamento Europeu e do Conselho. Portugal: Official Journal of the European Union, 2009. 
CORZO, M. A.; AFSHAR, M. Art and Eternity: The Nefertari Wall Paintings Conservation Project 1986 - 1992. Singapura: The J. Paul Getty Trust, 1993.

DONOVAN, T. It's All a Game: The History of Board Games from Monopoly to Settlers of Catan. [Ebook]. Thomas Dunne Books, 2017

DUARTE, L. C. S. Traços Distintivos de Estratégias em Jogos. 2015. Dissertação (Mestrado em Design) - Programa de Pós-Graduação em Design, Universidade Federal do Paraná, Paraná, 2015.

FORTY, A. Objetos de Desejo: Design e Sociedade desde 1750. São Paulo: Cosac Naify, 2007.

FRACALANZA, H.; NETO, J. M. O Livro Didático de Ciências: Problemas e Soluções. Ciência \& Educação (Bauru). Programa de Pós-Graduação em Educação para a Ciência, Universidade Estadual Paulista (UNESP), Faculdade de Ciências, campus de Bauru., v. 9, n. 2, p. 147-157, 2003.

GAGNÉ, R. M. Como se Realiza a Aprendizagem. $1^{\text {a }}$ Edição, Reimpressão. Rio de Janeiro: Ao Livro Técnico S. A., 1965 (1973 tradução).

GARDNER, M., Knots and Borromean Rings, Rep-Tiles, and Eight Queens. New York: Cambridge University Press, 2014.

HAM, Ethan. Tabletop Game Design for Video Game Designers. Focal Press. Burlington, Boston, Estados Unidos da América, 2016.

HUIZINGA, J. Homo Ludens: a study of the play-element in culture. Routledge \& Kegan Paul: London, 1949. Available at: $<\underline{\text { http://art.yale.edu/file columns } / 0000}$ /1474/homo ludens johan huizinga routledge 1949_pdf> Access: 29 jan, 2021.

- Homo Ludens: o jogo como elemento da cultura. $8^{\text {a }}$ Edição. São Paulo: Perspectiva, 2018.

IBGE (Brasil). A pirâmide etária brasileira serve para nos fornecer informações importantes sobre natalidade, idade média da população, longevidade, entre outros temas. [s.1.], 2019?. Available at: $<$ https://educa.ibge .gov.br/jovens/conheca-o-brasil/populacao/18318-piramide-etaria.html $>$ Access on: 29 jan. 2021.

IFILL, S. A, Do Appearances Matter?: Judicial Impartiality and the Supreme Court in Bush v. Gore, 61 Md. L. Rev. 606 (2002) Available at: < http://digital commons.law.umaryland.edu/mlr/vol61/iss3/6> Access on 29 jan. 2021.

JARA, David. A Closer Look at the (Rule-) Books: Framings and Paratexts in Tabletop Role-playing Games. International Journal of Role-Playing, n. 4, University of Tampere, Finland, Abril, 2012.

JENKINS, B. Marginalization within Nerd Culture: Racism and Sexism within Cosplay, The Popular Culture Studies Journal, V. 7, No. 2, p. 157-174. (p. 158)

KURTZ, L. B. CARRION, R. C. A. Inception! A Relação do Jogador com a Materialidade da Plataforma Tabletop Simulator. SBC - Proceedings of SBGames 2018, V. 17, p 948-951, Paraná, outubro, 2018.

LÉSTE, J. V.; MONT'AlVÃO, C.; CARVAlho, M. C. Manuais de Jogos Enquanto Objetos Educativos: o desenvolvimento de estratégia em jogos analógicos como situações de aprendizado. SBC - Proceedings of SBGames 
2019, V. 18, p 1188 - 1191. Rio de Janeiro - RJ - Brazil, October 28th - 31th, 2019 - ISSN: 2179-2259

LÉSTE, J. V.; MONT'ALVÃO, C. Diretrizes para Características Didáticas de Manuais e Vídeo Tutoriais de Jogos Analógicos. Proceedings of the 17th ERGODESIGN \& USIHC 2019, Rio de Janeiro, RJ.

Diretrizes para Características Didáticas de Manuais e Vídeo Tutoriais de Jogos Analógicos. Revista Ergodesign \& HCI, v. 7 n. Especial (2019): Número Especial - Artigos do Ergodesign \& USIHC 2019 2019, Rio de Janeiro, RJ.

. Age Ratings for Tabletop Games' Usage in Brazil: analysis and suggestion of new criteria. Senses \& Sensibility - 10th UNIDCOM/IADE Biennal International Conference in Design, Lisbon, 2019 - Awaiting Publication.

LÉSTE, J. V.; Eventos de Jogos Analógicos Enquanto Ferramentas de Construção Identitária LGBTQI+ SBC - Proceedings of SBGames 2020, V. 19. Rio de Janeiro - RJ

LIMA, J. M. O jogo como recurso pedagógico no contexto educacional. São Paulo, Cultura Acadêmica : Universidade Estadual Paulista, Pró-Reitoria de Graduação, 2008 157p. ISBN 978-85-98605-48-7

MACKLIN, Ryan. 11 Rules for Board Game Rules Writing. 6 fev, 2015. Available at: <http://ryanmacklin.com/2015/02/11-rules-board-game-writing/> Access on: 10 set. 2019.

MEGHANI, Z.; KUZMA, J. (2018) Regulating animals with gene drive systems: lessons from the regulatory assessment of a genetically engineered mosquito, Journal of Responsible Innovation, 5:sup1, S203-S222, DOI: 10.1080/23299460.2017.1407912

MINISTÉRIO DA EDUCAÇÃO (Brasil). Guia do Programa Nacional do Livro Didático. 2019. Available at: <https://pnld.nees.com.br/assets-pnld/guias /Guia_pnld_2020_pnld2020-projetos-integradores-1.pdf> Access on: 13 set. 2019.

MORAES, A. Ergonomia e projeto de produtos, informação, interfaces da interação homem-computador e espaços arquiteturais: ensino e pesquisa, XXIII Encontro Nac. de Eng. de Produção - Ouro Preto, MG, Brasil, 2003.

NICOLAU, M.; PIMENTEL, L., Os Jogos de Tabuleiro e a Construção do Pensamento Computacional em Sala de Aula, Congresso Sobre Tecnologias na Educação. Volume 3, p 44-56, Ceará, 2018.

PICCOLO, Gustavo Martins, JOGO OU BRINCADEIRA: Afinal, de que estamos falando? Motriz, Rio Claro, v.15 n.4 p.925-934, out./dez. 2009

PRATES, A. M. [Correspondência eletrônica via WhatsApp]. Destinatários: João Léste, Júlia Martins e Isabella Mendes. [S. l.], 2019. 1 mensagem.

QUASDORF, T., 2020. Turning Votes into Victory Points: Politics in Modern Board Games. gamevironments 13, 103-137. Available at: < $\underline{\text { http://www.game }}$ vironments.uni-bremen.de> Access on: 29 jan. 2021

ROWLEY, J. The Wisdom Hierarchy: representations of the DIKW hierarchy. Journal of Information Science Vol. 33, 2007. 
SÆVEROT, H.; TORGERSEN, G. E. . Individual Differences in Visual and Verbal Channel Capacity and Learning Outcome from Film and Text. Creative Education, 7, (2016). ISSN 2845-2867. http://dx.doi.org/10.4236/ce.2016.718264 STOLEE, M. J. An Object-focused Approach to Analog Game Adaptation. 2020. Thesis (Master of Science in Computational Media) - University of California, September 2020. Available at: <https://escholarship.org/content/ qt80p2b848/qt80p2b848.pdf> Access on: 29 jan. 2021.

TEIXEIRA, B. F. Diversidade e Inclusão nas organizações: o desafio da inclusão de pessoas transgênero no mercado de trabalho formal. Rio de Janeiro: UFRJ, 2019.

Theory: Playtest from the Rulebook. [S. l.]. Available at: $<$ https://lawofgame design.com/2015/09/14/theory-playtest-from-the-rulebook/> Acess on: 29 jan, 2021.

TOCCI, J. Geek Cultures: Media and Identity in the Digital Age. Pennsylvania: University of Pennsylvania, 2009.

TRILLA, J.; et al. Educação Formal e Não Formal: Pontos e Contrapontos. São Paulo: Summus, 2008.

TUFTE, Edward Rolf. The Visual Display of Quantitative Information. Graphics Press, Cheshire Connecticut, 1983.

UCL. The Book of the Dead: Chapter 17. [S. l.]. Available at: $<\underline{\text { https: } / / w w w . u c l}$ .ac.uk/ museums-static/digitalegypt/literature/religious/bd17.html $>$ Access in: 29 jan. 2021.

Unger, G. Legible? Emigre, n. 65, p. 100-111, 2003. Available at: $<$ https://www.emigre.com/Essays/Magazine/Legible>. Access on: 29 jan. 2021.

\section{1}

\section{Complementary Bibliography}

ATTEWELL, P. What is skill? Work and Occupations, V. 17, N. 4. Sage Publications: [s.1], 1990. Available at: $<$ https://motamem.org/wp-content/uploads/ 2018/09/What-Is-Skill-Paul-Attewell.pdf> Access on: 29 jan. 2021.

BARDIN, L. Análise de Conteúdo. São Paulo: Edições 70, 2016.

BARON, R. A.; KALSHER, M. J. Psychology: From Science to Practice, Capítulo 6. Allyn \& Bacon, Boston, 2005.

BERKELEY, G. Tratados Sobre os Princípios do Conhecimento Humano. São Paulo: Editora Escala, 2006.

BROUGÉRE, G. Jogo e a Educação. Porto Alegre: Artes Médicas, 1998.

CARVALHO, L. R. R.; OLIVEIRA, F. N. O Jogo de Regras Rummikub e a Relação Interpares: Processos de Interdependência Social, Cognitiva e 
Afetiva. Revista Ibero-Americana de Estudos em Educação, São Paulo, Volume 6, Número 2, Páginas 228-240, 2011.

FINKEL, U. On the Rules for the Royal Game of Ur. Ancient board games in perspective: papers from the 1990 British Museum colloquium with additional contributions. Ed. by I. L. Finkel. London, British Museum Press, 2007. ISBN: 0-7141-1153-8; 978-0-7141-1153-7. Available at: $<$ https://csclub.uwaterloo.ca/ pbarfuss/On the Rules for the Royal Game of Ur.pdf> Access on 14 mar. 2021.

FREITAS, N. K., RODRIGUES, M. H. O Livro Didático ao Longo do Tempo: a forma do conteúdo. $\mathbf{1 8}^{\circ}$ Seminário de Iniciação Científica. Universidade do Estado de Santa Catarina, 2008.

GIL, A. C. Como Elaborar Projetos de Pesquisa. 4a Edição. São Paulo: Editora Atlas S.A., 2002.

GÖKYAY FOUNDATION, History of Chess. [S. l.]. 2015. Available at: $<\underline{w w}$. gokyay satrancvakfi.org.tr/ en/library/history-of-chess> Access on: 29 jan. 2021.

GRAY, D. E. Pesquisa no Mundo Real. Ed. 2. São Paulo: Editora Penso, 2012.

MARQUES, G. N. R. M. Ludus maximus: aprendendo conteúdos históricos em ambientes informais na Educação de Infância - desafios e obstáculos. $\quad 4^{\circ}$

Encontro sobre Jogos e Mobile Learning, p. 255-263, Coimbra, Portugal. Maio, 2018.

MENEZES, C. C. N.; BARTOLI, R. Gamificação: surgimento e consolidação. C\&S - São Bernardo do Campo, v. 40, n. 1, p. 267-297, jan./abr. 2018.

MONT'ALVÃO, C.; MORAES, A. Ergonomia: Conceitos e Aplicações. $4^{\mathrm{a}}$ Edição. Teresópolis: 2AB Editora Ltda, 2010.

SALES, J. C. O mobiliário egípcio: a tecnologia da madeira. Revista da Associação Cultural de Amizade Portugal-Egipto, $\mathrm{n}^{\mathrm{o}}$ 3, p 91-113, Lisboa, Portugal. Novembro, 2015.

SANTOS, Flávio Marcelo Risuenho dos, SOUSA, Richard Perassi Luiz de. O Conhecimento no Campo de Engenharia e Gestão do Conhecimento. Belo Horizonte: Perspect. ciênc. inf. vol.15 no.1, Apr. 2010.

https://csclub.uwaterloo.ca/ pbarfuss/On_the_Rules_for_the_Royal_Game_of_Ur .pdf

\section{2}

Ludography

BÖSCH, H. Black Stories. [S. l.] Boosterbox.nl, 2004. Available at: $<\underline{\text { https:// }}$ boardgamegeek.com/boardgame/18803/black-stories>, Access on: 14 mar. 2021.

KÖHRSEN, A. Black Stories Junior: Green Stories. [S. l.] MINDOK, 2009. Available at: $<$ https://boardgamegeek.com/boardgame/43043/black-stories-juniorgreen-stories $>$, Access on: 14 mar. 2021. 
FRAGA, R. Dr. Eureka. [S. l.] Blue Orange Games, 2015. Available at: $<\underline{\text { https:// }}$ boardgamegeek.com/boardgame/181345/dr-eureka>. Access on: 14 mar. 2021.

GIMMLER, T. No Thanks!. [S. l.]. AMIGO, 2004. Available at: $<\underline{\text { https://board }}$ gamegeek.com/boardgame/12942/no-thanks > Access on: 14 mar. 2021.

HALABAN, S.; ZATZ, A. Quartz. [S. l.]. Mandala Jogos, 2015. Available at: $<$ https://boardgamegeek.com/boardgame/172881/quartz/> Access on: 14 mar. 2021.

LOPEZ, F., War in Rio. [S. l.]. Self published. Nov. 2007. Available at: $<$ www.jogowarinrio. blogspot.com> Access on: 29 jan. 2021.

LOPEZ, F., Bando Imobiliário. [S. l.]. Self published. 14 dez. 2010. Available at: $<$ https://bando imobiliario.wordpress.com/> Access on: 29 jan. 2021.

LOPEZ, F., Design Against Humanity. [S. l.]. Self published. 16 out. 2018. Available at: <www.behance.net/gallery/70664191/Design-Against-Humanity> Access on: 29 jan. 2021.

MOGENDORFF, J. J. Combate. [S. l.; s. d.]. Estrela. Available at: $<\underline{\text { https://www. }}$ ludopedia.com.br/jogo/stratego> Access on: 14, mar. 2021.

. Stratego. [S. l.]. Carlit, 1946. Available at: <https://boardgamegeek.com/ boardgame/1917/stratego/> Access on: 14, mar. 2021.

ROBBINS, M., Uno. [S. l.]. Self Published, 1971.

(Uncredited). Bagh Chal. [S. n.], Nepal, 1000. Available at: $<$ https://boardgame geek.com/boardgame/315/bagh-chal> Access on: 13 mar. 2021.

(Uncredited). Cows and Leopards. [S. n.; s. d.], Sri Lanka. Available at:

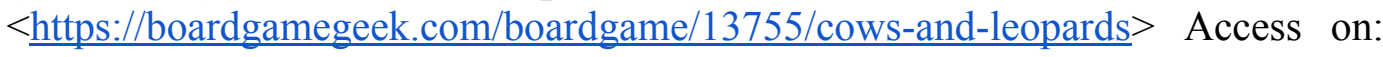
13 mar. 2021.

(Uncredited). Resta-Um. [S. l.; s. $n . ; \quad s$. d.]. Available at: $<\underline{\text { https://super.abril }}$ .com.br/comportamen to/jogo-resta-um/> Access on: 29 jan. 2021.

(Uncredited). Jogo da Onça. [S. l.; s. n.; s. d.]. Available at: $<\underline{\text { https://www.ludo }}$ pedia.com.br/jogo/jogo-da- onca> Access on: 29 jan. 2021.

(Uncredited). Hnefatafl. [S. l.; s. $n . ; s . d$.]. Available at: $<\underline{\text { https://www.ludope }}$ dia.com.br/jo go/hnefatafl> Access on: 29 jan. 2021.

(Uncredited). Chess. [S. l.; s. n.], 1475. Available at: $<$ https://boardgamegeek.com/ boardgame/171/chess $>$ Access on: 14 mar. 2021.

(Uncredited). Fox and Geese. [S. 1.; s. n.] 1400. Available at: $<$ https://boardgame geek.com/boardgame/10213/fox-and-geese > Access on: 14 mar. 2021. 


\section{3}

\section{Videos}

COUP - Como Jogar. [S. l.: s. $n$.], 2017. 1 video (19 min). Publicado pelo canal Romir Play House. Available at: <www.youtube.com/watch?v=6UpW8dV2Oks> Access on: 29 jan. 2021.

COUP - Review por Jogando Offline (s02e01). [S. l.: s. $n$.], 2014. 1 video (24 min). Publicado pelo canal Jogando Offline. Available at: $<w w w . y o u t u b e . c o m / w a t c h$ ? $=$ NB7rwNVHBgo $>$ Access on: 29 jan. 2021.

FOI GOLPE | Gigante Leo, Defante, Jhonny, Rosana e Ulisses Mattos jogam COUP | De Quem é a Vez? [S. l.: s. n.], 2019. 1 video (25 min) Publicado pelo canal Rafael Studart. Available at: <https://www.youtube.com/watch ? $\mathrm{V}=$ bwbaMEPm1dY $>$ Access on: 29 jan. 2021.

JACK Explicador - Coup. [S. l.: s. $n$.], 2014. 1 video (33 min). Publicado pelo canal Meeple TV. Available at: <https://www.youtube.com/watch?v=nw WCJdN32wA. > Access on: 29 jan. 2021.

LET'S Play COUP feat. Brennan Lee Mulligan from CollegeHumor | Overboard, Episode 12. [S. l.: s. $n$.], 2019. 1 video (30 min). Publicado pelo canal Polygon. Available at: <https:/www.youtube.com/watch?v= BrjCPnbEMfE $>$ Access on: 29 jan. 2021.

LOVE Letter \& Coup: Fine Brothers and Felicia Day Join Wil Wheaton. [S. l.: s. n.], 2015. 1 video (44 min). Publicado pelo canal Geek \& Sundry. Available at $<$ https://www.youtube.com/watch? $\mathrm{v}=\mathrm{k} 2$ YUYPDq7gQ> Access on: 29 jan. 2021.

NEMESIS - How To Play. [S. l.: s. $n$.], 2019. 1 video (50 min). Publicado pelo canal Board Game Replay. Available at: <https://www.youtube.com/ watch? $v=$ g1NnAHptaeE $>$ Access on: 29 jan. 2021.

ORIGINAL Santorini Kickstarter Campaign. [S. l.: s. $n$.], 2018. 1 video (4 min) Publicado pelo canal Roxley. Available at: <https://www.youtube.com/ watch? $v=$ IBfGD8aq7Is\& $>$ Access on: 29 jan. 2021.

Tom Scott vs Irving Finkel: The Royal Game of Ur | PLAYTHROUGH | International Tabletop Day 2017 [S. 1.: s. n.], 2017. 1 video (25min). Published by the channel The British Museum. Available at: $<$ https://www.youtube.com/ watch? $\mathrm{v}=$ WZskjLq040I\&ab channel $=$ TheBritishMuseum $>$ Access on: 14 mar. 2021.

SANTORINI - Expansion Tutorial - The Golden Fleece. [S. l.: s. n.], 2016. 1 video (1 min) Publicado pelo canal Roxley. Available at: < https://www. youtube.com/watch? v=fKQSQCisWTI> Access on: 29 jan. 2021.

SANTORINI - God Card Tutorial - Apollo. [S. l.: s. n.], 2016. 1 video (1 min) Publicado pelo canal Roxley. Available at: <https://www.youtube.com/ watch? $\mathrm{v}=95 \mathrm{EHcOSfwsY}>$ Access on: 29 jan. 2021. 
SANTORINI - God Card Tutorial - Bia. [S. l.: s. n.], 2016. 1 video (1 $\mathrm{min})$ Publicado pelo canal Roxley. Available at: <https:/www.youtube.com/watch? $\mathrm{v}=\mathrm{rENxFkF04aw}>$ Access on: 29 jan. 2021.

SANTORINI- God Card Tutorial - Circe. [S. l.: s. $n$.], 2016. 1 video (1 min) Publicado pelo canal Roxley. Available at: <https://www.youtube.com/watch? $\mathrm{v}=\mathrm{Z7RY} 6 \mathrm{w} 2 \mathrm{wGt} 0>$ Access on: 29 jan. 2021.

SANTORINI - God Card Tutorial - Europa \& Talus. [S. l.: s. n.], 2018. 1 video (1 min) Publicado pelo canal Roxley. Available at: <https://www.youtube.com/ watch? $\mathrm{v}=2 \mathrm{gOzUefcL68}>$ Access on: 29 jan. 2021.

SANTORINI - God Card Tutorial - Gaia. [S. l.: s. n.], 2019. 1 video (1 $\mathrm{min}$ ) Publicado pelo canal Roxley. Available at: <https://www.youtube.com/watch? $\mathrm{v}=9$ ufs YvR19Aw> Access on: 29 jan. 2021. 


\section{Appendix I - Interview Script}

Objetivos da entrevista: Determinar qual a metodologia aplicada pelos desenvolvedores de manuais ao redigir o documento.

Público alvo: Redatores de Manuais de Instrução para Jogos (sejam os próprios game designers ou pessoas que fazem essa tarefa especificamente)

Pontos de atenção: Os critérios são similares aos apontados no artigo do Ergodesign?

\section{Perguntas Introdutórias:}

- Nome, idade, profissão:

- Qual a sua formação?

\section{Perguntas e objetivos:}

1. Há quanto tempo você trabalha com jogos e manuais? você costuma desempenhar outras funções no projeto do jogo?

○ Já conhece o mercado e o funcionamento das empresas?

○ É Exclusivamente Redator?

2. Qual você acha que é a função mais importante no projeto?

- Identificar se alguma das pessoas entrevistadas citará a redação do manual como mais importante

3. Na sua opinião, há algum curso ou formação que oferece mais subsídios para quem realiza essa tarefa?

○ Existe algum curso ou formação que as treine?

4. Você acredita que a sua formação (Se tiver) te ajuda a projetar os manuais? 
- Identificar aspectos de diferentes formações que podem contribuir para a tarefa de redigir o manual.

5. Quais habilidades você acha que uma pessoa que escreve um manual precisa ter?

- Identificar as habilidades que consideram necessárias para completar a tarefa de redigir os manuais. Será que habilidades diferentes são apontadas por profissionais diferentes?

6. Você já produziu o manual de algum jogo que você não projetou? Quais insumos você recebeu para poder redigir o manual?

- Geralmente, como é a comunicação entre as equipes envolvidas no projeto?

- Em que etapa da produção o manual é feito?

- No caso de redatores que não projetaram o jogo, costumam ter acesso ao jogo físico para projetar o manual adequadamente?

7. Geralmente, como é o processo para redigir o manual?

- Existem dificuldades comuns para a redação de todos os manuais?

- Quanto tempo dura esse processo de redação do manual?

8. Em qual etapa do processo de projetar o jogo o manual costuma ser redigido? Geralmente, você testa ele com usuários?

- Ele é integrado no projeto, ou feito posteriormente?

9. Você tem algum critério para organizar as informações do manual? Se sim, qual?

- Existem critérios particulares para cada redator, ou há algum consenso geral?

○ Esses critérios são explícitos e costumam ser verificados?

10. Qual o melhor manual que você já fez? 
- Exemplos práticos de manuais que sejam considerados bons.

○ Oportunidade de análise dos critérios utilizados.

11. E o pior? Por que?

- Exemplos práticos de manuais que sejam considerados ruins.

○ Oportunidade de análise dos critérios utilizados.

12. Você acredita que se tivesse uma pessoa cuja função fosse só escrever o manual, o resultado final do manual seria melhor?

- Identificar se consideram que a atividade de redigir o manual deve ser uma especialidade da pessoa que realiza a tarefa, ou se consideram que os game designers são capazes de realizá-la 


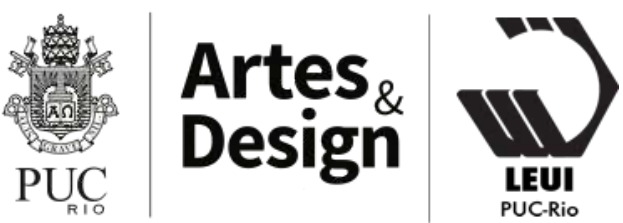

\section{Appendix II - Informed Consent Form (Interview)}

\section{TERMO DE CONSENTIMENTO LIVRE E ESCLARECIDO}

Documento que se dirige a quem vai participar de uma pesquisa.

Traz as informações necessárias para a pessoa avaliar se deseja participar.

Só assine se você concordar com as condições deste termo.

\section{Programa de Pós Graduação em Design da PUC-Rio}

LEUI | Laboratório de Ergodesign e Usabilidade de Interfaces da PUC-Rio

Título da Pesquisa: A Ergonomia Informacional de Manuais e Regras de Jogos

Analógicos: Análise da hierarquia e ordenação das informações

Nome do Pesquisador Responsável: João Vitor Léste

Nome da Orientadora da Pesquisa: Claudia Mont'Alvão

Gostaríamos de convidar você a participar como voluntária(o) de uma entrevista virtual.

$\mathrm{O}$ estudo é uma etapa da pesquisa que estamos fazendo na PUC-Rio. Conheça os detalhes!

\section{OBJETIVO | O que queremos investigar}

O objetivo desta entrevista é investigar as opiniões técnicas de pessoas que têm experiência redigindo manuais de jogos sobre a ordenação de informações dos mesmos.

\section{JUSTIFICATIVA | Por que esta pesquisa é relevante}

Com esta pesquisa, pretende-se gerar novos conhecimentos no que diz respeito a parâmetros ergonômicos para o desenvolvimento de manuais de jogos, uma área ainda pouco explorada academicamente, no Brasil. O resultado deste trabalho, pelo seu foco no design centrado no usuário, poderá ser também útil tanto para designers independentes quanto para empresas produtoras de jogos.

\section{PROCEDIMENTOS METODOLÓGICOS | Como será a sua participação}

Se você decidir fazer parte desta entrevista, será solicitado que você, individualmente, responda perguntas elaboradas pelo pesquisador, usando sua experiência particular como referência. A entrevista será realizada em horário acordado entre ambas as partes, em chamada de vídeo e/ou áudio em uma das seguintes plataformas, à sua escolha: WhatsApp, Skype, Zoom, ou Google Hangouts.

\section{INFORMAÇÕES COLETADAS | Os dados que armazenaremos e como iremos} usá-los

A partida do jogo será filmada e o pesquisador conduzindo-a poderá anotar suas observações e comentários em um bloco de notas. Caso seu rosto apareça em alguma imagem, ela será descaracterizada (na forma de 'borrão') para que você não seja reconhecido(a). Os resultados serão utilizados para usos futuros da pesquisa e estarão disponíveis para os participantes a qualquer momento. 


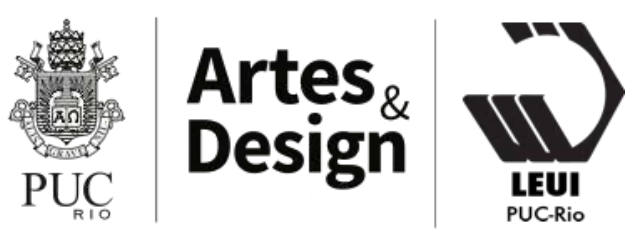

\section{BENEFÍCIOS | O que você ganha}

Você não irá se beneficiar de nenhuma forma direta por participar desta dinâmica. Não há nenhuma remuneração por sua participação nesta dinâmica. No entanto, sua participação é essencial para a condução dela e a sequência da pesquisa em andamento. Você poderá se beneficiar de forma indireta caso ache a atividade agradável ou se sinta bem em auxiliar o andamento da pesquisa.

\section{CUSTOS | O que você gasta}

Você não terá nenhum custo como resultado de seu consentimento em participar do workshop, além dos seus custos regulares de uso de internet e energia para acessar seu computador ou celular.

\section{DIREITOS DOS PARTICIPANTES | O que você pode fazer}

Você é livre para encerrar a sua participação a qualquer momento, sem nos avisar. Isso não implicará em qualquer prejuízo para você. Toda nova informação sobre essa pesquisa será passada para você avaliar se deseja continuar participando. Você poderá solicitar a interrupção da gravação e o cancelamento da atividade. Será possível fazer uma pausa no meio da atividade, se você quiser.

\section{SIGILO E CONFIDENCIALIDADE DE DADOS | Como protegemos a sua identidade}

Para proteger o sigilo de sua identidade, seu nome não aparecerá em nenhuma publicação. Caso necessário, você receberá um pseudônimo (um nome falso) que será usado em vez de seu nome. Todo o material de registro em áudio, vídeo ou fotografias será tratado como confidencial e restrito para fins acadêmicos.

\section{DESCONFORTOS E RISCOS}

O grau de desconforto será mínimo, semelhante a fazer atividades cotidianas no computador, como ler noticiário e preencher formulários. Os riscos são próximos de zero. Entretanto, caso você sinta algum desconforto ou cansaço em função da duração da atividade, pode informar ao pesquisador responsável para que seja feita uma pausa ou, caso você deseje, a atividade seja encerrada.

\section{AUTORIZAÇÃO PARA USO DE IMAGEM E DECLARAÇÕES}

Ao assinar este termo, você autoriza o uso das suas declarações e imagem - sempre descaracterizada - para finalidades acadêmicas - artigos acadêmicos, dissertações de mestrado, teses de doutorado, aulas, papers, sites, apresentações em simpósios ou congressos científicos relacionados ao tema.

\section{FICOU COM DÚVIDAS?}

Você poderá intervir e questionar o pesquisador sempre que achar necessário ou tiver alguma dúvida. Se você tiver alguma dúvida sobre esta pesquisa, você também pode contatar o pesquisador responsável, João Léste, pelo telefone (21) 99657-3696 ou pelo endereço de e-mail jvleste95@gmail.com. A orientadora da pesquisa, Claudia Mont'Alvão, também pode ser contactada pelo telefone (21) 98106-3100 ou pelo endereço de e-mail cmontalvao@puc-rio.br. Caso deseje, você também pode contactar 
Câmara de Ética/PUC-Rio, Rua Marquês de São Vicente, 225 - Gávea, Rio de Janeiro, CEP 22453-900, telefone: (21) 3527-1618.

$\mathrm{Eu}$, , $\mathrm{CPF}$ após ler este documento e esclarecer todas as minhas dúvidas, acredito estar suficientemente informada(o). Está claro para mim que minha participação é voluntária e que posso retirar este consentimento a qualquer momento, sem penalidades ou perda de qualquer benefício. Estou ciente também dos objetivos da pesquisa, dos procedimentos aos quais serei submetida(o), dos possíveis danos ou riscos deles provenientes e da garantia de confidencialidade e esclarecimentos sempre que desejar. Concordo de espontânea vontade em participar deste estudo, afirmando ser maior de 18 anos.

Rio de Janeiro, de de 2020.

\section{A quarentena e o distanciamento social causados pela pandemia da COVID-19, que ocorreu durante a realização da nossa pesquisa, impediram a impressão desse termo em duas vias. $A$ assinatura da(o) participante foi coletada por meio de resposta positiva em troca de e-mails.}

Nome do pesquisador responsável:

João Vitor Léste

Assinatura do pesquisador responsável:

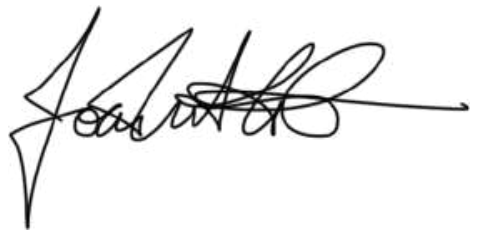




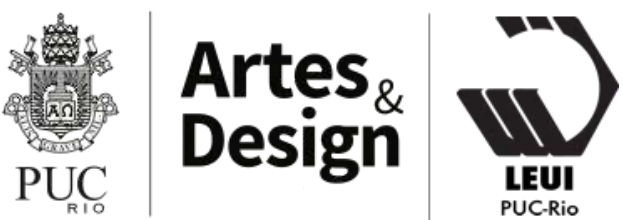

\section{Appendix III - Informed Consent Form (Experiment)}

\section{TERMO DE CONSENTIMENTO LIVRE E ESCLARECIDO}

Documento que se dirige a quem vai participar de uma pesquisa.

Traz as informações necessárias para a pessoa avaliar se deseja participar. Só assine se você concordar com as condições deste termo.

\section{Programa de Pós Graduação em Design da PUC-Rio}

\section{LEUI | Laboratório de Ergodesign e Usabilidade de Interfaces da PUC-Rio}

Título da Pesquisa: A Ergonomia Informacional de Manuais e Regras de Jogos

Analógicos: Análise da hierarquia e ordenação das informações

Nome do Pesquisador Responsável: João Vitor Léste

Nome da Orientadora da Pesquisa: Claudia Mont'Alvão

Gostaríamos de convidar você a participar presencialmente como voluntária(o) de um estudo experimental. O estudo é uma etapa da pesquisa que estamos fazendo na PUC-Rio. Conheça os detalhes!

\section{OBJETIVO | O que queremos investigar}

O objetivo deste experimento é investigar a capacidade de pessoas de lerem e interpretarem as informações presentes em manuais de jogos, além de quais as possíveis dificuldades para a compreensão das mesmas.

\section{JUSTIFICATIVA | Por que esta pesquisa é relevante}

Com esta pesquisa, pretende-se gerar novos conhecimentos no que diz respeito a parâmetros ergonômicos para o desenvolvimento de manuais de jogos, uma área ainda pouco explorada academicamente, no Brasil. O resultado deste trabalho, pelo seu foco no design centrado no usuário, poderá ser também útil tanto para designers independentes quanto para empresas produtoras de jogos.

\section{PROCEDIMENTOS METODOLÓGICOS | Como será a sua participação}

Se você decidir fazer parte deste experimento, será solicitado que você leia o manual de instruções de dois jogos e em seguida, jogá-los. O primeiro jogo será o "No, Thanks!"; você deverá ler o manual do jogo e depois participará de uma partida com outros(as) 2 ou 3 participantes. O segundo jogo será o "SET", e você deverá seguir o mesmo procedimento. Estes manuais poderão ser a versão original ou uma versão alterada pelo pesquisador responsável, mas não será informado a você com qual das duas você está interagindo. Durante a leitura do manual e a sessão de jogo, você não poderá tirar dúvidas sobre as regras do jogo com o pesquisador responsável, devendo usar somente o manual fornecido para você como fonte de informações. Você poderá discutir, com os demais jogadores, a qualquer momento, as suas dúvidas quanto ao jogo.

\section{INFORMAÇÕES COLETADAS | Os dados que armazenaremos e como iremos} usá-los 
A partida do jogo será filmada e o pesquisador conduzindo-a poderá anotar suas observações e comentários em um bloco de notas. Caso seu rosto apareça em alguma imagem, ela será descaracterizada (na forma de 'borrão') para que você não seja reconhecido(a). Os resultados serão utilizados para usos futuros da pesquisa e estarão disponíveis para os participantes a qualquer momento.

\section{BENEFÍCIOS| O que você ganha}

Você não irá se beneficiar de nenhuma forma direta por participar desta dinâmica. Não há nenhuma remuneração por sua participação nesta dinâmica. No entanto, sua participação é essencial para a condução dela e a sequência da pesquisa em andamento. Você poderá se beneficiar de forma indireta caso ache a atividade agradável, caso se sinta bem em auxiliar o andamento da pesquisa, ou caso desfrute da companhia das demais pessoas participando da atividade.

\section{CUSTOS | O que você gasta}

Os participantes não terão nenhum custo como resultado de seu consentimento em participar do workshop.

\section{DIREITOS DOS PARTICIPANTES | O que você pode fazer}

Você é livre para encerrar a sua participação a qualquer momento, sem nos avisar. Isso não implicará em qualquer prejuízo para você. Toda nova informação sobre essa pesquisa será passada para você avaliar se deseja continuar participando. Você poderá solicitar a interrupção da gravação e o cancelamento da atividade. Será possível fazer uma pausa no meio da atividade, se você quiser.

\section{SIGILO E CONFIDENCIALIDADE DE DADOS| Como protegemos a sua identidade}

Para proteger o sigilo de sua identidade, seu nome não aparecerá em nenhuma publicação. Caso necessário, você receberá um pseudônimo (um nome falso) que será usado em vez de seu nome. Todo o material de registro em áudio, vídeo ou fotografias será tratado como confidencial e restrito para fins acadêmicos.

\section{DESCONFORTOS E RISCOS}

Você pode sentir desconforto ou constrangimento caso não consiga interpretar adequadamente as regras do manual com o qual entrará em contato. No entanto, uma vez que a dinâmica será realizada com outras pessoas - que também estarão jogando esses jogos pela primeira vez, apresentando dúvidas quanto aos procedimentos - seu desconforto ou constrangimento poderá ser minimizado. Você também pode sentir desconforto ou cansaço em função da duração da atividade. Neste caso, pode informar ao pesquisador responsável para que seja feita uma pausa ou, caso você deseje, a atividade seja encerrada.

O risco excepcional, associado à situação de pandemia, é: contaminação pelo vírus Covid-19. Para contornar esses riscos, minimizando-o serão tomadas as seguintes medidas: (1) Somente serão convidadas para a participação pessoas que declarem estar praticando a quarentena rigorosa, segundo as recomendações de segurança da OMS e autoridades nacionais brasileiras; (2) Somente serão convidadas pessoas que morem nas redondezas do local onde será realizado o experimento, para que o risco de contágio no trajeto seja mínimo; (3) Somente serão convidadas pessoas que já frequentem o local de realização do jogo, para que não sejam expostas a novos riscos em função da realização 
do experimento; (4) $\mathrm{O}$ local de jogo será a residência do pesquisador, devidamente esterilizada antes, durante e depois das sessões de jogo, com o uso de álcool 70 em todas as superfícies e objetos que serão manipulados; (5) Serão oferecidas luvas e máscaras descartáveis para todas as pessoas que participarem do experimento; (6) As sessões de jogo contarão com entre 3 e 4 participantes, minimizando o contato entre pessoas; (7) Todas as pessoas participantes receberão um frasco com álcool gel, para ser usado com discrição própria, e que poderá ser reposto, caso necessário (8) será observada e respeitada a distância minima de 2 metros entre os participantes;

\section{AUTORIZAÇÃO PARA USO DE IMAGEM E DECLARAÇÕES}

Ao assinar este termo, você autoriza o uso das suas declarações e imagem - sempre descaracterizada - para finalidades acadêmicas - artigos acadêmicos, dissertações de mestrado, teses de doutorado, aulas, papers, sites, apresentações em simpósios ou congressos científicos relacionados ao tema.

\section{FICOU COM DÚVIDAS?}

Você poderá intervir e questionar o pesquisador sempre que achar necessário ou tiver alguma dúvida. Se você tiver alguma dúvida sobre esta pesquisa, você também pode contatar o pesquisador responsável, João Léste, pelo telefone (21) 99657-3696 ou pelo endereço de e-mail jvleste95@gmail.com. A orientadora da pesquisa, Claudia Mont'Alvão, também pode ser contactada pelo telefone (21) 3527-1595 ou pelo endereço de e-mail cmontalvao@puc-rio.br. Caso deseje, você também pode contactar Câmara de Ética/PUC-Rio, Rua Marquês de São Vicente, 225 - Gávea, Rio de Janeiro, CEP 22453-900, telefone: (21) 3527-1618.

$\mathrm{Eu}$, , CPF após ler este documento e esclarecer todas as minhas dúvidas, acredito estar suficientemente informada(o). Está claro para mim que minha participação é voluntária e que posso retirar este consentimento a qualquer momento, sem penalidades ou perda de qualquer benefício. Estou ciente também dos objetivos da pesquisa, dos procedimentos aos quais serei submetida(o), dos possíveis danos ou riscos deles provenientes e da garantia de confidencialidade e esclarecimentos sempre que desejar. Concordo de espontânea vontade em participar deste estudo, afirmando ser maior de 18 anos.

Rio de Janeiro, de de 2020 .

Nome do pesquisador responsável: João Vitor Léste

Assinatura do pesquisador responsável:

Assinatura da pessoa participante: 


\section{Appendix IV - Experiment's Datasheet}

\section{Selected games:}

1. No Thanks! - A set collection game in which players must score the lowest by trying to collect cards that form numerical sequences or, even better, not collecting cards at all.

2. SET - A set collection game in which players must try to form combinations of cards (SETs) faster than any other players.

\section{Justification for the selection:}

Both games are very similar in key aspects that render them more easily comparable amongst themselves:

1. They both are well known games that have been released for sale more than 15 years ago

2. Both have similar complexity ratings on BoardGameGeek's community poll: between 1 (Light) and 2 (Medium Light).

3. Both are card games that encourage players to combine cards amongst themselves, evoking similar concepts and principles.

4. Both are fast games, with average playing time of 30 minutes or under.

5. Both have very simple rulebooks, with only 2 pages each.

6. Both have rulebooks that are not in compliance with the proposed criteria for the organization of information.

7. Both have rulebooks that are in compliance with the proposed criteria for imagem usage, reducing the number of variables being evaluated.

8. Neither of them have player aids, making it so that all players have to share one common rulebook.

9. Neither of them require players to have previous knowledge about miscellaneous topics - aside from basic mathematical skills.

10. Both games allow for groups between $3-7$ players to participate. 


\section{Preliminary Hypothesis:}

By altering the order in which the contents of rulebooks are displayed in order to be in compliance with the proposed criteria, players who play the game for the first time will perform better, while also having a more positive outlook on reading rulebooks.

\section{Independent Variable:}

The order in which information is displayed onto the chosen rulebooks.

\section{Dependent Variables:}

1. Time elapsed reading the rulebook (minutes and seconds);

2. Quantity of mistakes made by each player during a game session;

3. Amount of times that the game was interrupted in order to check the rules;

4. Time elapsed during interruptions (minutes and seconds).

\section{Intervening Variables - and how to avoid them:}

1. Player's familiarity with the game - they must have never played the game before participating in the experiment;

2. Player's age - they must eligible to play according to the game's official age rating, which are compliant with proper math skills required to play the game, according to the BNCC;

3. Player's schooling degree - they must all be within 2 years of acquiring their bachelor's degree, either before or after;

4. Amount of Players - all groups must be composed of $3-4$ players.

\section{Application Guidelines:}

1. Each group of players will play one match of each of the selected games;

2. Regardless of the group, the first game will be "No, Thanks" - the one with the lower complexity score - and the second will be "SET" - the one with the higher complexity score; 
3. Odd groups $(1 \mathrm{st}, 3 \mathrm{rd}, 5 \mathrm{th}, \ldots)$ will interact with No Thanks!'s original rulebook and SET's revised rulebook, while even groups $(2 \mathrm{nd}, 4 \mathrm{th}, \ldots)$ will interact with No Thanks!'s revised rulebook and "SET"s original rulebook;

4. Each group will receive only one copy of each rulebook - in order to imitate a real game scenario - and are free to interact with it as they see fit;

5. The lead researcher cannot answer any questions regarding the games' rules.

\section{Evaluation of the Rulebooks:}

After playing each game, each playes will be asked to comment on what they thought about the rulebook, while also receiving a black and white photocopy of it, if they want to make any notes.

\section{Data Analysis:}

1. Quantitative comparison between each players the resulting dependent variables being collected, in order to rank the participants performance amongst their own group.

2. Quantitative comparison between each groups' performance - determined by both mean, median, and mode.

3. Qualitative analysis about player's perceptions about the rulebooks. 